AN ARC OF DEATH: SUICIDE, ALCOHOLISM, MURDER, ACCIDENTS, AND
OTHER EARLY DEATHS IN ST. LOUIS, MISSOURI, 1875 TO 1885

\author{
A Dissertation \\ presented to \\ the Faculty of the Office of Graduate Studies \\ at the University of Missouri-Columbia \\ In Partial Fulfillment \\ of the Requirements for the Degree \\ Doctor of Philosophy \\ by \\ SARAH LIRLEY MCCUNE \\ Dr. LeeAnn Whites, Dissertation Supervisor \\ MAY 2018
}


(C) Copyright by Sarah Lirley McCune 2018

All Rights Reserved 
The undersigned, appointed by the dean of the Office of Graduate Studies, have examined the thesis entitled

AN ARC OF DEATH: SUICIDE, ALCOHOLISM, MURDER, ACCIDENTS, AND OTHER EARLY DEATHS IN ST. LOUIS, MISSOURI, 1875 TO 1885

presented by Sarah Lirley McCune, a candidate for the degree of doctor of philosophy and hereby certify that, in their opinion, it is worthy of acceptance.

Professor LeeAnn Whites

Professor Keona Ervin

Professor Mary Jo Neitz

Professor Linda Reeder

Professor Catherine Rymph 


\section{DEDICATION}

For Matt, who has loved and supported me throughout this process - and for accepting payment in cookies and brownies for being my research assistant. You have helped me achieve my greatest goals as a person and a scholar. I am so grateful to have you as my partner.

Also for Eeyore, Patches, and Burgundy for being delightful distractions and "helping" me throughout the process by literally being at my side almost every moment...even though your writing is gibberish. 


\section{ACKNOWLEDGEMENTS}

Thank you to my wonderful advisor, LeeAnn Whites, who has encouraged and supported me throughout my graduate career. Thank you for guiding me for nearly eight years and for encouraging me to use an exciting source that I hope to continue to use in future projects.

I also appreciate the help and support of my dissertation committee: Keona Ervin, Mary Jo Neitz, Linda Reeder, and Catherine Rymph. You have all given me numerous ideas for my work and it is stronger because of it.

My friends and colleagues in Professor Whites' Writing Group and outside of it have also improved my work immeasurably through conversations, book recommendations, and comments on my drafts: Megan Boccardi, Mary Beth Brown, Autumn Dolan, Danielle Griego, Caitlin Lawrence, Bill Lewis, Leroy Rowe, Darin Tuck, Andrea Weingartner, and Cassie Yacovazzi. Last, but not least, is Paula Hunt, who has read and improved almost all of my work!

Several professors have given me feedback on my work as well, especially on conference papers: Alison Efford, Lorri Glover, Diane Miller Sommerville, and Terri Snyder-thank you.

I would also like to thank librarians, archivists, and editors for helping me access materials and improve my scholarship: the staff at the Missouri State Archives in Jefferson City, Mike Everman at the Missouri State Archives in St. Louis, Kenneth Winn, and the staff at the State Historical Society of Missouri, including John Brenner, Kimberly Harper, and Mary Ellen Lohmann. 
Finally, I would like to thank the office staff who have made my graduate career and dissertation process much easier and more enjoyable: Patty Eggleston, Melinda Lockwood, Lynn Summers, and Nancy Taube.

My work would not have been possible without funding from several sources: The Colonial Dames of America, The Center for Missouri Studies and its Women in Missouri Politics Fellowship, the William E. Foley Research Fellowship from the Missouri State Archives, and a Dissertation Fellowship from the Department of History at the University of Missouri. 


\section{TABLE OF CONTENTS}

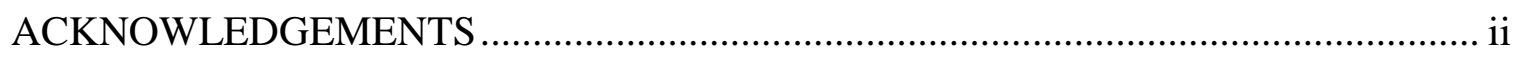

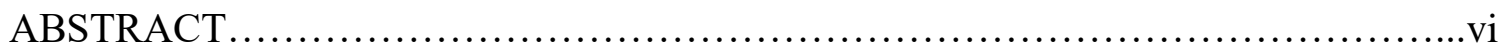

INTRODUCTION: Politics of Death Investigations

in Late-Nineteenth-Century St.

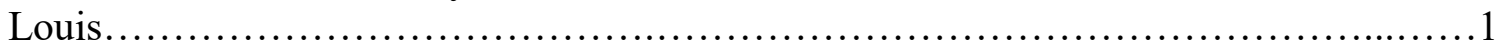

CHAPTER ONE: "Whilst Laboring Under Mental Derangement:"

Politics of Suicide Verdicts................................................................................. 19

CHAPTER TWO: Not Quite Suicide: Alcohol as a Contributor to Untimely Deaths ......44

CHAPTER THREE: "With the Intention of Producing an Abortion:"

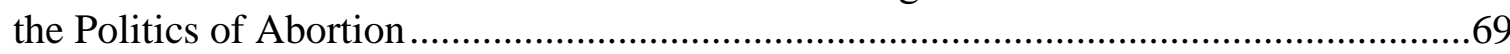

CHAPTER FOUR: Desperate Deeds and Murderous Plots: Homicide

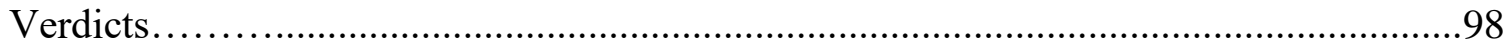

CHAPTER FIVE: "No one is to blame:"

Accidental Deaths................................................................. 133

CHAPTER SIX: Not as Simple as Disease: Coroners' Verdicts of

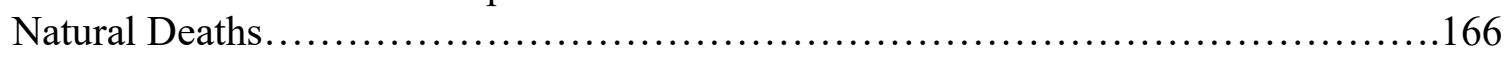

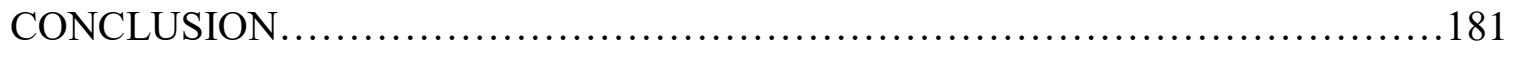

TABLES AND

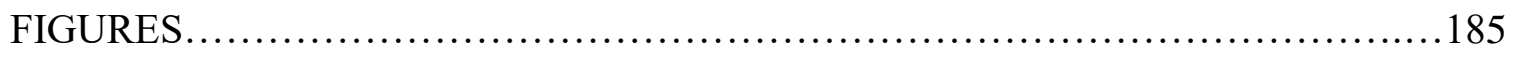

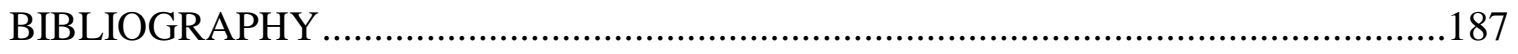

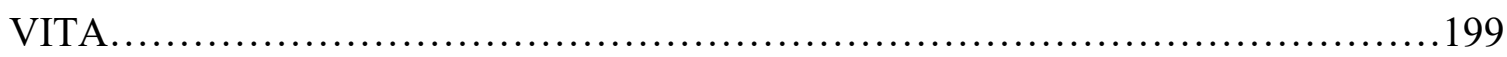




\section{LIST OF ILLUSTRATIONS}

Figure

Page

1. Data Analyzed by Chapter.................................................. 184

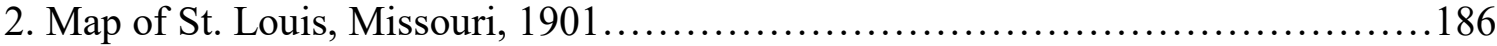




\title{
AN ARC OF DEATH: SUICIDE, ALCOHOLISM, MURDER, ACCIDENTS, AND OTHER EARLY DEATHS IN ST. LOUIS, MISSOURI, 1875 TO 1885
}

\author{
Sarah Lirley McCune \\ Dissertation Supervisor: Dr. LeeAnn Whites
}

\begin{abstract}
In this study of 120 coroner's inquests conducted in St. Louis between 1875 and 1885, the author examines how six different kinds of deaths were investigated and interpreted. Each chapter focuses on a different cause of death: suicide, alcohol-related deaths, deaths caused by complications from abortions, homicides, accidents, and natural deaths. While coroners ultimately determined how and why a person died, their verdicts were informed by their interviews with witnesses and were subsequently reported on by the press. By viewing death investigations from three social locations - that of the investigating coroner, witnesses in the inquest, and newspaper reporters - it becomes apparent that three factors were the most important factors in investigating and interpreting deaths. These factors were whether the deceased had family members who testified on their behalf, whether the coroner believed that it was possible that another person may have caused or contributed to the death that he was investigating, and the reputation of the deceased. Coroners did not investigate all deaths the same way, but based them on their own assumptions as well as their training and Missouri law. The ways in which these men and women lived shaped not only how they died, but how their deaths were investigated and interpreted.
\end{abstract}




\section{Introduction: Politics of Death Investigations in Late-Nineteenth-Century St. Louis}

J.W. McElvain decided to go fishing with some friends in Cahokia on July 11, 1881, an incredibly hot day. He and his friends fished for a while, but on the ferry ride back to St. Louis, McElvain complained that he was not feeling well. He felt well enough to walk ahead of his friends once they returned to the city, however, and his friends quickly lost sight of him. McElvain never made it home. He collapsed on the corner of Eleventh and Lafayette streets, likely because of the oppressive heat that day. A crowd gathered around him and one man gave him some whiskey while he was lying on the ground - either because he requested it or because this stranger believed that it would help. McElvain died on that corner soon after collapsing there. ${ }^{1}$

Deputy Coroner Herman Praedicaw investigated McElvain's death and quickly concluded that he died "from the effects of sunstroke," a verdict that he and Coroner John Frank rendered for dozens of people during a heat wave in July of 1881. But Praedicaw made no mention of alcohol use in his verdict, which differed from other men and women who died during the heat wave. Even when they had dozens of heat-related deaths to investigate, coroners distinguished between deaths that were caused by heatstroke alone and those in which illness or alcohol use were contributing factors. The fact that the coroners differentiated between heatstroke and heatstroke exacerbated by alcohol use during a time in which they were overwhelmed with cases illustrates that they based their death investigations and verdicts on factors beyond their own professional standards,

${ }^{1}$ J.W. McElvain Inquest, July 11, 1881, Case No. 226, Folder 27, Box 26 (Missouri State Archives microfilm roll C31278), St. Louis City Office of the Coroner-Inquests 1845-1900, Missouri State Archives, Jefferson City, Missouri. Hereafter the record will be referred to as "McElvain Inquest." 
including their assumptions about race, class, gender, and reputation. In McElvain's case, a witness told the deputy coroner that the deceased was drinking, but he testified that a man was giving the deceased whiskey, not that McElvain drank of his own accord. No other witness testified to the coroner that McElvain was a heavy or regular drinker. The witness testimony likely explains why the deputy coroner did not add "intemperance" to his verdict because McElvain, like other men and women who received verdicts of heatstroke and intemperance, was single, working-class, and resided in a boardinghouse - not indicators of a bad reputation, but also not the hallmarks of a respectable, prominent one.

J.W. McElvain's death is just one of 120 coroners' inquests examined in this study and illustrates that despite their medical training, experience, and professional standards, St. Louis coroners conducted death investigations and rendered verdicts based on their assumptions about race, class, gender, and reputation. ${ }^{2}$ By interrogating six different types of coroner's verdicts, it is apparent that factors beyond their own policies shaped their decisions. Coroners tended to conduct lengthier investigations into the deaths of men and women who were respected members of their communities and whom

\footnotetext{
${ }^{2}$ Because thousands of inquests exist for the city of St. Louis between 1845 and 1900, I narrowed the time frame to a ten-year period: 1875 to 1885 , a time period that features ample witness testimony in most inquests as well as the opportunity to study families in greater depth by using the federal census, which does not exist for 1890. Even for a ten-year period, thousands of inquests exist, so the initial sample came from viewing every case for every fourth month of each year, but only for men and women between the ages of twenty and fifty, in order to better study violent deaths, which are more likely to occur for that age range. The first sample yielded 868 coroner's inquests. Final selections were based on themes: prostitution, family violence, abortion, murder-suicides, and verdicts of insanity. In addition, a variety of deaths within the six categories chosen for this study were included, such as burns and falls for accidental deaths. Finally, an approximately equal number of cases involving men and women as well as a range of ages, dates, and races and ethnicities were selected for each chapter, including an oversampling of women murderers and inquests into the deaths of African Americans because so few appear in this study. Upon close reading and review, some cases were not included because the age did not fit within the range of 20 to 50. One case was also added because while the deceased was younger than 20 , her mother was in the original sample. Therefore, the final sample was 113 cases, not 120.
} 
they understood to be good wives, husbands, mothers, and fathers. In addition to scrutinizing the coroner's verdicts and death investigations, this study examines newspaper accounts of these deaths and witness testimony, all of which demonstrate that, in some cases, coroners did not understand what caused these deaths, nor were they always interested in determining an accurate cause of death.

To understand how coroners conducted their investigations and rendered their verdicts, this work is organized by cause of death. Following an arc of death, the first three chapters explore verdicts that claim that the deceased took his or her own life in some way: by suicide, alcohol use, or abortion. Then, the next two chapters examine verdicts in which the coroner determined that someone else took the life of the deceased: homicides. Finally, to understand how coroners determined that ordinary causes resulted in death, the fifth and sixth chapters study verdicts of accidental deaths and deaths from natural causes. Organizing the work by verdict reveals how the coroners conducted their investigations and determined causes of death in a variety of kinds of cases. While these verdicts make it seem as though these types of deaths were quite different — suicide as opposed to alcoholism, for instance - in some cases, the causes of death were similar. If a coroner did not expect to have to request city officials to press charges, then he may not even bother to render an accurate verdict, which was often the case with natural deathsthose caused by illness or disease.

While coroners ultimately determined how and why a person died, their verdicts were informed by their interviews with witnesses and were subsequently reported on by the press. By viewing death investigations from three social locations - that of the investigating coroner, witnesses in the inquest, and newspaper reporters-it becomes 
apparent that three factors were the most important factors in investigating and interpreting deaths. These factors were whether the deceased had family members who testified on their behalf, whether the coroner believed that it was possible that another person may have caused or contributed to the death that he was investigating, and the reputation of the deceased.

St. Louis coroners operated within a flawed system. Coroners were elected officials and often held their positions for only two to four years, meaning that a quick succession of coroners made it difficult to retain institutional knowledge. Being elected also meant that they had to campaign for office. The coroner's office also had a limited budget and one that was scrutinized by city officials and the public. St. Louis coroners were licensed, practicing physicians who had far more education and training than Missouri law required. Many practiced medicine during the Civil War, in their own practices in the 1870 s and 1880 s, and some even taught at local medical schools. Each coroner was assisted by at least one deputy coroner, but he did not have the same training as his supervisor. Many deputy coroners had no medical or legal training before holding office. Still, deputy coroners investigated many cases on their own, usually those that the coroner's office believed would be simple to solve. Coroners investigated more difficult cases, such as cases of suspected homicide, sometimes with the assistance of their deputy coroners. In instances of suspected homicide or other suspicious deaths in which someone else may have been responsible, the coroner convened a jury to render the verdict, as prescribed by Missouri law. A jury of six white men heard witness testimony, viewed the corpse, and listened to autopsy results before rendering a verdict. In most cases, however, coroners and deputy coroners investigated and rendered verdicts without 
a jury. They spoke to friends, relatives, bystanders who literally witnessed these deaths, physicians, and police officers to determine how and why a man or woman died-by suicide, homicide, accident, or natural causes_-with some variation among each kind of death. Whether or not the coroner held a jury inquest, in some cases, he would also order an autopsy to be performed by a local physician to determine the cause of death. Coroners depended on witness testimony and, in some cases, autopsy results from local physicians and a jury's decision to render their verdicts. ${ }^{3}$

Missouri law was not the only factor that prevented coroners from investigating deaths objectively: their belief systems did as well. While coroners were trained officials, they were human beings who had assumptions about the men and women whose deaths they were investigating based on their experiences and norms of their time. Coroners were highly educated, middle-class, able-bodied, white men-social locations that shaped their experiences and views of the world. They lived in a society in which white men held the most social and political power. They operated within a gender system in which men were supposed to be breadwinners, while women were supposed to be mothers and moral guardians of the home, although many African American and working-class women worked for wages and also ran their households. In part because

\footnotetext{
3 Between 1875 and 1900, St. Louis deputy coroners investigated most cases without direct supervision of the Coroner, but they were officially supervised by coroners and were also appointed by coroners Although many deputy coroners were not trained physicians, some were medical doctors. Max Aaron Goldstein, editor, One Hundred Years of Medicine and Surgery in Missouri: Historical and Biographical Review of the Physicians and Surgeons of the State of Missouri and Sketches of Some of Its Notable Medical Institutions (St. Louis: St. Louis Star, 1900); The Mayor's Message with Accompanying Documents, to the Municipal Assembly of the City of St. Louis, for the Fiscal Year Ending April 12 $2^{\text {th }}, 1897$, Printed for the Municipal Assembly, 1898, 702. Information regarding coroners and their deputies was found using census data, death certificates, and city directories, which listed few as physicians by trade. U.S. Bureau of the Census, 1850, 1860, 1870, 1880, 1890, 1900, 1910, 1920; Missouri Death Certificates, Missouri State Archives, Jefferson City, Missouri, accessed online: http://www.sos.mo.gov/archives/resources/deathcertificates/default.asp [accessed July 2011].
} 
of their assumptions, coroners were more likely to investigate the deaths of respected white men and women more thoroughly than those of disreputable men and women and African Americans - those who worked as prostitutes, drank regularly, beat their wives, or lived in what were considered to be rough neighborhoods.

The assumptions that coroners made based on race, class, and gender were not the only factors that shaped their investigations and verdicts, though; they relied heavily on the testimony of people who knew the deceased well to render their verdicts. Coroners especially trusted family members to learn about the deceased's state of mind shortly before their deaths - if he or she was insane, a habitual drinker, or had financial or romantic troubles. Even in instances of accidental deaths when family members were not present, coroners interviewed relatives first and put their testimony ahead of others in their records. When coroners rendered verdicts of alcoholism or insanity, it was not because of their medical training, but because of the testimony of the loved ones of the deceased. Conversely, when men or women did not have family members or close friends to testify on their behalf, coroners were less likely to render sympathetic verdicts to soften the stigma of certain kinds of deaths, such as suicides and deaths caused by alcoholism. Without family members to interview, coroners were also more likely to conduct shorter investigations. Relatives even impacted the coroner's decision about the ultimate decision of a cause of death; in some cases, coroners decided that deaths were caused by accidents, not suicide, because of the statements given by family members.

The St. Louis press often reported witness testimony and the coroner's verdicts verbatim in their news accounts, but they often wrote sensationalistic accounts. For the press especially, the reputation of the deceased impacted how they interpreted his or her 
death. Their accounts were, in some cases, at odds with people who knew the deceased well. Reporters sympathized with prominent residents of St. Louis and even ordinary men and women if they understood them to be respected members of their communities and good men and women. They almost always used racist language to describe the deaths of African Americans, however, even if they described their deaths with some sympathy. In contrast, men and women who deviated from white, middle-class gender conventions received little or no sympathy from reporters and, in some cases, were blamed for their deaths - even when they were homicide victims. The press loved sensationalistic stories to sell newspapers - especially murders. They reported on homicides most often, then suicides and accidents. Reporters seldom wrote about alcohol-related deaths, abortions, and even many natural deaths. They wrote about the deceased's every virtue if they were respectable: that they left children behind, were good parents and spouses, hard workers, and esteemed members of the community. For those who had questionable reputations, however, the press blamed them for their suicides, accidents, or even murders and detailed every one of their supposed transgressions, such as affairs, working as prostitutes, or abusing their wives and children.

Other historians have studied coroner's inquests, but have not focused on their practices and verdicts, and instead used verdicts to study larger social changes - such as urban violence and industrialization. The earliest historians used inquests to better understand the process of urbanization and how and why violence, notably homicide, suicide, and accidental deaths, changed over time. More recent studies have continued this trend, but with a narrower focus on one cause of death and with more attention to 
race, class, and gender. ${ }^{4}$ But these historians have assumed that coroners' verdicts were a reliable way to study violence, even while pointing out that city officials, such as police forces, created new categories of violence that falsely inflated statistics. They also did not to consider the possibility that coroners conducted more investigations into the deaths of the working class and poor than the middle and upper classes, which, as this study shows, they did, even in cases of natural deaths. ${ }^{5}$

One historian has pointed out the tendency for coroners to conduct most of their inquests into the deaths of the working class and poor and raises a question that this study answers: Stephen Berry. He mentions in a footnote that only further research will reveal how and why the records were biased. He notes that coroners were "probably...more likely to investigate the deaths of the friendless and the poor, and more likely to investigate deaths that occurred in public rather than private spaces," but does not speculate as to why this occurred. ${ }^{6}$ In fact, coroners tended to investigate deaths that occurred in public spaces more thoroughly than those that occurred in private ones, in part to determine if hospital or asylum attendants, carriage drivers, or employers were at fault for these deaths. Another reason that coroners' investigations were thorough in

\footnotetext{
${ }^{4}$ Roger Lane, Violent Death in the City: Suicide, Accident \& Murder in $19^{\text {th }}$ Century Philadelphia (Cambridge, Massachusetts: Harvard University Press, 1979); Jeffrey S. Adler, First in Violence, Deepest in Dirt: Homicide in Chicago, 1875-1920 (Cambridge: Harvard University Press, 2006); Stephen Berry, "The Historian as Death Investigator," in Weirding the War: Stories from the Civil War's Ragged Edges, Stephen Berry, ed. (Athens: University of Georgia, 2011): 176-188.

${ }^{5}$ For historical works regarding how coroners and medical examiners conducted death investigations, see: J. Maxwell Atkinson, Discovering Suicide: Studies in the Social Organization of Sudden Death (Pittsburgh: University of Pittsburgh Press, 1978); Jeffrey M. Jentzen, Death Investigation in America: Coroners, Medical Examiners, and the Pursuit of Medical Certainty (Cambridge, Mass.: Harvard University Press, 2009); Stefan Timmermans, Postmortem: How Medical Examiners Explain Suspicious Deaths (London: The University of Chicago Press, 2006); Michelle McGoff-McCann, Melancholy Madness: A Coroner's Casebook (Douglas Village, Cork: Mercier Press, 2003); James C. Mohr, Doctors and the Law: Medical Jurisprudence in Nineteenth-Century America (New York: Oxford University Press, 1993).

${ }^{6}$ Berry, "The Historian as Death Investigator," 186.
} 
bars, hotels, and hospitals than in homes and boardinghouses was because there were often more witnesses to interview in public than in private spaces.

Berry also did not understand why, overwhelmingly, the men and women whose deaths triggered a coroner's investigation were poor or working-class, but this study answers that question as well. One important reason for this is because wealthier residents of St. Louis could pay family physicians to falsify death certificates and were less likely to be surrounded by nosy neighbors in tenements or boardinghouses who could notify the coroner of a sudden suicide or abortion that they were trying to conceal. ${ }^{7}$ Even in cases of natural deaths a coroner investigated if there was no attending physician, which was more likely to be the case for the poor and working-class than for the middle and upper classes. The few cases for affluent residents of St. Louis stand out because of their rarity and the investigations into these deaths differ markedly from those of the poor

${ }^{7}$ Although some historians of death investigations have found that coroners concealed some suicides, this study shows that family members, not coroners, tended to attempt to hide suicide, abortions, or other stigmatized acts. Coroners even sometimes recorded verdicts that reflected their suspicion of a different cause of death (such as "supposed accident"). It is unknown how often coroners altered their verdicts because of pressure from families, but the evidence from this study shows that it was rare. For examples of efforts to conceal deaths caused by abortion from coroners, see: Annie E. Roberts Inquest, December 6 and 7, 1878, Case No. 044, Folder 23, Box 13 (Missouri State Archives microfilm roll C31274), St. Louis City Office of the Coroner-Inquests 1845-1900, Missouri State Archives, Jefferson City, Missouri. The testimony is missing from Roberts' inquest, but the St. Louis Globe-Democrat reprinted much of it verbatim: "Sin and Death," St. Louis Globe-Democrat, Saturday, December 7, 1878, 2; "Many Such.: Sad Case of Abortion and Morphine Poisoning," St. Louis Post-Dispatch, September 5, 1882, 7. For examples of coroners who suspected that men and women died by suicide or homicide, but rendered verdicts of accident based on the evidence available, especially family testimony, see: Mary Scott Inquest, January 27, 1883, Case No. 1331, Folder 59, Box 32 (Missouri State Archives microfilm roll C31280), St. Louis City Office of the Coroner-Inquests 1845-1900, Missouri State Archives, Jefferson City, Missouri; Mary Harris Inquest, June 18, 1880, Case No. 2087, Folder 38, Box 22 (Missouri State Archives microfilm roll C31276), St. Louis City Office of the Coroner-Inquests 1845-1900, Missouri State Archives, Jefferson City, Missouri; “Was it Suicide?," St Louis Globe-Democrat, Saturday, June 19, 1880, 8; "The Coroner," St. Louis Globe-Democrat, Sunday, June 20, 1880, 4; Stefan Timmermans observes that well-connected families also often paid to have "suicides classified as accidents and unsavory details to be suppressed" in Postmortem: How Medical Examiners Explain Suspicious Deaths (London: The University of Chicago Press, 2006), 4. Michelle McGoff-McCann makes a similar observation, noting that the deceased's relatives often pressured coroners to avoid suicide verdicts. Michelle McGoff-McCann, Melancholy Madness: A Coroner's Casebook (Douglas Village, Cork: Mercier Press, 2003), 34. 
and working class because of their length as well as the tendency of coroners to render more sympathetic verdicts (such as claiming that the deceased died by suicide during a bout of insanity). ${ }^{8}$

While poor and working-class white men and women are overwhelmingly represented in this study, African Americans of all classes are not because of both the small population of African Americans as well as racism. African Americans comprised between one and seven percent of the city's residents between 1875 and $1885 .^{9}$

Approximately twelve percent of the inquests in my original sample were conducted into the deaths of African-Americans, or about twice the population of St. Louis, indicating that African-Americans frequently died sudden, early deaths. ${ }^{10}$ Coroners, the press, and white witnesses all treated the deaths of black men and women differently than they did those of whites, regardless of ethnicity or immigrant status. Each inquest into the death of an African American featured the abbreviation "col." next to it, for "colored," and this notation was often made for black witnesses as well. Newspapers were more critical of African Americans than they were of whites, as were coroner's juries. ${ }^{11}$

Despite their limitations, coroner's inquests are incredibly useful, however, particularly for studying the white working class. Each inquest offers a glimpse of an

${ }^{8}$ Of 868 cases, coroners investigated the deaths of 244 middle-class or affluent residents of St. Louis, 399 deaths of working-class men and women, and 244 deaths of members of unidentified classes.

${ }^{9}$ Corbett, 101-102.

${ }^{10}$ Census data shows that in $1870,351,189$ people lived in St. Louis, while in 1900, that number rose to 575, 238. Census Data, 1870, 1880, 1890, 1900, in the "Historical Census Browser," University of Virginia Library, http://mapserver.lib.virginia.edu/php/county.php [accessed June 15, 2011]. Of the original sample in this study of 868 coroner's inquests, only 106 were for African Americans, or about twelve percent - a higher percentage than the city's black population.

${ }^{11}$ Of my original sample of 868 cases, 106 were conducted into the deaths of African Americans, 436 into the deaths of a variety of immigrant men and women, 272 into the deaths of native-born whites, and 54 into the deaths of men and women whose race or ethnicity I could not determine. 
individual during a time of crisis. One may learn about the person's familial, workplace, and community relationships for years or months, but it is often a matter of only days or hours. Staff at the coroner's office recorded the testimony of witnesses verbatim, so these records provide a valuable source to study the lives of ordinary men and women who did not have the education or leisure time to write letters or diaries. The daily lives of these individuals and their families is revealed in these records. Census records, used in conjunction with inquests, provide a way to trace the members of a family and their relationship to each other before and after the date of the inquest. Marriage, death, cemetery, military, and other vital records provide these details as well. Finally, some cases have associated paper collections with scrapbooks and diaries, allowing for an insider's view of family dynamics over many years.

St. Louis is a fascinating city to study because of its rich record source, expanding population, and its location in between the North and South - a growing industrial center, but one in a former slaveholding state with a number of former Confederate residents, including some investigating coroners. St. Louis had vice districts, saloons, immigrant neighborhoods, African American communities, affluent areas, and a variety of public institutions - the dynamics of which are apparent in coroner's inquests. Inquest records only exist for some counties in Missouri and only for a limited number of years, with over twenty thousand inquests being available for the city of St. Louis in the nineteenth century. ${ }^{12}$ Because of its large size and number of government institutions, there are a

\footnotetext{
12 St. Louis City Office of the Coroner's inquests 1845-1900, in the "Coroner's Inquest Database," Missouri State Archives, http://www.sos.mo.gov/archives/resources/coroners/[accessed 27 June 2017]; St. Louis city coroners conducted 13, 112 inquests between 1875 and 1885. There are 22, 293 coroner's inquests for the years between 1845 and 1900. 22,000 of those were conducted between 1870 and 1900 . The difference is likely because of record preservation, not how many inquests were conducted, because there are more detailed records for the 1870 s to 1900 than before as well as more records in general. St. Louis City Office of the Coroner's inquests 1845-1900, in the “Coroner's Inquest Database," Missouri
} 
wealth of additional archival sources to supplement St. Louis coroner's inquests: criminal and civil court records, city guides, biographies, city newspapers, census records, and even some paper collections. St. Louis grew in the late nineteenth century and featured strong industries as well as river commerce, in addition to social institutions such as a large police force, facilities for the poor, several jails, schools, and benevolent organizations.

St. Louis had a diverse population, particularly a large immigrant population, and coroner's inquests reveal racism toward African Americans, but less bias toward immigrants. ${ }^{13}$ African Americans were beginning to migrate to the city in the 1870 s and 1880s, but faced limited work opportunities and often lived in tenements in poor and working-class neighborhoods—-some integrated, some not. ${ }^{14}$ Blacks comprised about one percent of the city's population in 1860 , but that rose to about seven percent by 1900. ${ }^{15}$ Many German immigrants lived and worked in St. Louis, often in their own German-speaking communities, but an immigrant status did not seem to prompt a negative bias in death investigations and newspaper coverage as it did with African Americans. Many Irish-born men and women appear in these records as well, and some negative stereotypes were evident, but not consistently.

State Archives, http://www.sos.mo.gov/archives/resources/coroners/ [accessed 27 June 2017]. Thank you, Dr. Mary Jo Neitz, for suggesting this sampling method.

${ }^{13}$ Of 868 inquests, 436 were conducted into the deaths of immigrants, including men and women from Canada, Sweden, Switzerland, France, and Italy, but primarily from Germany and Ireland.

${ }^{14}$ Katharine T. Corbett points out that African Americans tended to live in working-class and poor neighborhoods between 1860 and 1900, but, over time, the city created more policies to exclude them from better work, school, and housing opportunities. Corbett, 102.

${ }^{15}$ Corbett, 101-102. Census data shows that in 1870, 351, 189 people lived in St. Louis, while in 1900, that number rose to 575, 238. Census Data, 1870, 1880, 1890, 1900, in the "Historical Census Browser," University of Virginia Library, http://mapserver.lib.virginia.edu/php/county.php [accessed June 15, 2011]. Of the original sample in this study of 868 coroner's inquests, only 106 were for African Americans, or about twelve percent - a higher percentage than the city's black population. 
St. Louis also provides an opportunity to study gender roles and relations. Coroners' inquests reveal how men and women lived and worked in their homes, workplaces, and in other public places. While men were expected to be (and often were) breadwinners and heads-of-household, some also went to saloons, fought with other men at work, visited prostitutes, and beat their wives. Women were supposed to (and often did) manage their households and raise children, but they also worked for wages, ran boardinghouses, worked as prostitutes, drank regularly, and committed crimes.

The assumptions that coroners made about race, class, and gender are evident in the kinds of investigations they conducted and the verdicts that they rendered. Chapter One argues that men and women who died by suicide were more likely to receive verdicts of insanity or temporary insanity if they had family members who told the coroners that their loved ones were insane. Claiming that a man or woman died by suicide while suffering from insanity was a way that coroners mitigated the stigma of suicide, something important to family members for the sakes of their reputations as well as for burial practices for some faiths, such as for Catholics. Coroners rendered verdicts of suicide "whilst suffering from mental derangement" or "while laboring under temporary insanity" based on several factors, most notably the reputation of the deceased and the testimony of family members. Coroners relied on the testimony of family members to assess the deceased's state of mind more than their own medical knowledge or the testimony of other physicians. In addition, coroners only rendered verdicts of insanity for men and women with good reputations, which was based largely on their gender and family positions. Married mothers and fathers who were respected members of their communities were the most likely to receive these qualified verdicts, while 
unmarried men and women, particularly those isolated from relatives, were the least likely to receive these verdicts. Although many people who died by suicide experienced marital conflicts, alcohol and drug use, and mental and physical illnesses, these factors did not shape their death investigations and verdicts as much as did their reputations and testimony of relatives.

Alcoholism was not understood to be the same as suicide or insanity by coroners, family members or the press, the subject of Chapter Two. Some physicians who specialized in treating men and women for heavy, regular drinking considered alcoholism to be a form of insanity, but most did not. One notable exception exists not just in this study, but among the thousands of coroner's inquests that exist for St. Louis: a workingclass, respectable, Irish wife and mother who died from alcoholism and received a verdict of dipsomania, a term meaning alcohol insanity. No other man or woman received such a sympathetic verdict from a coroner. The press displayed no sympathy for men and women who died from alcohol-related illnesses and accidents and seldom even bothered to write about their deaths. Usually, when St. Louis reporters did write about their deaths, they did so as warning to others about the dangers of drinking. Unlike men and women who died by suicide, coroners and St. Louis reporters seldom tried to find a cause for deadly drinking, even when these men and women died after drinking binges. In some cases, friends and relatives told the coroner about possible causes for the deadly drinking of their loved ones, but it almost never changed coroners' verdicts or newspaper accounts. Coroners' verdicts make it seem as if alcohol alone killed men and women, but in some cases, their deaths were more complicated. 
Chapter Three examines deaths caused by complications from abortions and argues that although the practice was illegal, coroners and law enforcement officers tolerated the practice- except in cases of supposed malpractice. Coroners were most concerned when a physician performed an abortion that caused a woman's death. Coroners, some witnesses, and the press all treated women as helpless victims of socalled abortionists, disregarding the fact that women sought the services of these physicians and often tried to protect them from criminal charges. As with other causes of death, reputation, race, and class mattered. The relatives and friends of women who could afford to hire physicians to perform abortions sometimes had these physicians falsify death certificates and tried to conceal these unexpected deaths from coroners. When the press reported on deaths caused by abortion, which they seldom did, they discreetly discussed the abortion-related deaths of married, respectable women, noting that they died from operations. When physicians performed abortions that caused illness or death, the press, like investigating coroners, treated women as helpless victims.

Not all women were treated as victims, though, only respectable women, as evidenced by deaths caused by homicide examined in Chapter Four. Just as in other causes of death, the press, coroner's courts, and criminal courts treated men and women who committed homicides differently based on race, class, and reputation, and, to a lesser extent, gender. African American men and women faced stricter charges, longer sentences, and harsher criticism from the press than did their white counterparts. Conversely, the press exonerated some prominent white men of murder - even if witnesses and the coroner did not. Even some women who were killed by their husbands or lovers were blamed for their own murders by the press - if they were believed to be 
disreputable. Several men killed their wives and lovers after abusing them for years-a fact that witnesses told investigating coroners about, but the press and some friends and acquaintances of these men did not always recognize. While men committed homicides more often than did women, they often killed for the same reasons - struggles over power, status, and, in some cases, lovers. Coroners never found that any of these men and women who committed homicides were insane, unlike in deaths by suicide. While many men and women claimed that they acted in self-defense, coroners and their juries often rejected their claims. Although coroners, their juries, and some witnesses offered little sympathy for perpetrators of homicides, the press sometimes did. Even in cases in which newspaper reporters did not sympathize with men and women who killed others, they sensationalized their crimes and focused much more on murderers than their victims.

In cases of accidental deaths, the subject of Chapter Five, coroners and their juries determined that no one was responsible for a person's death even though in some cases employers, the deceased, or others (such as neighbors who started fires accidentally) took actions that caused these accidents. Accidental deaths occurred when men and women died in unexpected circumstances: falls, drownings, vehicle accidents, and accidents when equipment at work malfunctioned. Coroners' juries almost never found employers accountable for deadly workplace accidents because this was the era shortly before advocates sought legislation to protect workers. Although some family members of deceased men and women threatened to sue over workplace accidents, those threats never came to fruition. In only one case, a jury held someone (a supervisor) accountable for someone else's death, but he faced no criminal charges. The press wrote many news accounts of these accidents because they made for sensational stories, but reporters 
focused more on the companies' financial losses and insurance coverage than victims of accidents. As with other deaths, the men and women in this chapter tended to be respectable and close with their relatives, important factors not only because they shaped the coroner's investigations, but also because newspapers depicted their deaths as more tragic because they left relatives behind. Despite their sympathy for the deceased, the press still believed that no one was to blame in these tragedies - preventable or not.

Chapter Six, the final chapter, examines natural deaths and argues that despite quick investigations and verdicts of illness or disease, the deaths of these men and women were more complicated than the verdicts suggest. Some cases feature verdicts that were not entirely accurate, or feature times of death and other details that do not match witness testimony. In some cases, the verdicts of natural causes of death reflect a lack of thorough investigation rather than a truly easy-to-solve case, reflected in part by the fact that deputy coroners investigated over half of these deaths with no oversight from the supervising coroners. Coroners evidently assumed that these deaths would be easy to investigate because they were not looking for anyone else to potentially hold responsible for most of these deaths. As a result, they took these investigations less seriously than with other causes of death, even though most of these men and women were respectable and had close family members and friends to testify before the coroner. The press wrote few news accounts about natural deaths, but when they did, they wrote long and sympathetic ones for respected members of communities.

The men and women in this study all died unexpectedly and quite young, often in tragic circumstances, but investigations into their deaths and interpretations of their deaths varied based on their family relationships, reputations, and whether someone else 
caused or contributed to their deaths. Coroners did not investigate all deaths the same way, but based them on their own assumptions as well as their training and Missouri law. Family members offered critical testimony that shaped the verdicts of these coroners more than other factors, in many cases. If a coroner believed that a man died by suicide, for instance, he may conclude it was an accident based on the testimony of relatives. Finally, the reputation of these men and women contributed to the length of their death investigations, their verdicts and, especially, the interpretations of their deaths by the St. Louis press. The press offered sympathetic coverage for respected men and women, regardless of race or class, but often castigated those with questionable reputations, even blaming them for their own murders, in some cases. The ways in which these men and women lived shaped not only how they died, but how their deaths were investigated and interpreted. 


\section{Chapter One \\ "Whilst Laboring Under Mental Derangement": Politics of Suicide Verdicts}

Charles P. Johnson rushed home from his law office at 4:00 pm on September 2, 1879 , to attend to his wife, Estelle, who was very ill. Drs. Smith and Ware worked to treat her and told Charles the reason for his wife's sickness: an intentional overdose of arsenic. Panicked, he asked, "Great God! Ese? Why did you do this?" and she replied, "Oh pet, I could not help it."16 His panic subsided when Estelle seemed to get better, and Charles probably hoped that she would recover and finally overcome the melancholy from which she had suffered for months, since the death of their two-week-old daughter. Charles returned to his office, confident of his wife's recovery, and returned home that evening. Unfortunately, Estelle grew worse and passed away at 10:00 that night, leaving behind her husband and four children. Charles attributed his wife's suicide to a "mania" due to the loss of their two-week-old child. He claimed that her mental illness became especially acute because of her devotion to her family, adding that "there was no nobler, and truer little wife, or a more kinder and affectionate mother." 17 Coroner Hugo Auler investigated her death and rendered a qualified verdict of suicide, that is, a verdict of suicide with an explanation of mental illness - insanity, temporary insanity, grief, or a similar qualification. Auler determined that Johnson died by suicide as a result of "mental aberration, caused by grief at the death of her child."18 There was no medical basis for this verdict. Drs. Ware and Smith discussed only her symptoms, evidence of

\footnotetext{
${ }^{16}$ Estell Johnson Inquest, September 3, 1879, Case No. 1576, Folder 77, Box 18 (Missouri State Archives microfilm roll C31275), St. Louis City Office of the Coroner-Inquests 1845-1900, Missouri State Archives, Jefferson City, Missouri. Hereafter this case will be referred to as "Johnson Inquest." Special thanks to Matt McCune for conducting nearly all of the census and vital record research for this chapter.

17 Johnson Inquest.

18 Ibid.
} 
arsenic poisoning, their efforts to treat her, and her death; they mentioned nothing about insanity. Johnson's family, however, told the coroner about a history of despondency since her last child died. ${ }^{19}$

The suicide of Estelle Johnson is just one of nine qualified suicide verdicts that will be investigated in this chapter and is just one example that demonstrates that the testimony of family members was central to determining that a man or woman who died by suicide suffered from insanity. ${ }^{20}$ Especially in deaths by suicide, coroners relied on the testimony of spouses, children, siblings, and parents to understand how and why a person came to his or her death. Coroner Hugo Auler and his colleagues relied on the statements of family members more than their own medical knowledge or the advice of other physicians to render verdicts of mental illness. They also rendered qualified verdicts to lessen the stigma of a suicide ruling, which could tarnish a family's reputation or prevent burial in a Catholic cemetery. ${ }^{21}$ Every wife and mother and most husbands and fathers in this study received a qualified verdict from the investigating coroner, that is, they received a verdict of suicide with an explanation of mental illness. Coroners rendered these qualified verdicts for a few reasons. First, most of these men and women had family members to explain to the coroner why they died by suicide-grief, melancholy, or, for men, a loss of employment. Second, relatives, neighbors, and

\footnotetext{
${ }^{19}$ Johnson Inquest.
}

20 These nine cases were selected from twenty-nine cases from the total sample of 120 cases. Of the twenty-nine cases, eighteen feature qualified verdicts, that is, verdicts in which the coroner adds an explanation for the suicide, often insanity or temporary insanity. Cases were selected for this chapter based on ample information in the inquest and cases that contrasted with each other. Similar cases to those discussed in this chapter will be footnoted throughout.

${ }^{21}$ Historian Terri Snyder notes that between the sixteenth and nineteenth centuries, coroners often rendered qualified verdicts to help their families avoid punishment for the crime of suicide. Terri L. Snyder, "What Historians Talk About When They Talk About Suicide: The View from Early Modern British North America." History Compass 5, no. 2 (2007): 659. 
investigating coroners understood these men and women to have been respectable men and women - those who represented the ideals of manhood and womanhood at the time. Family members, friends, and newspaper reporters described these women as loving, devoted to their husbands and children, and the creators of warm, comfortable homes, regardless of their class. Similarly, they described these men as loving, hardworking, and devoted to their families. Finally, in each case, family members told investigating coroners that their loved ones suffered from what they understood to be insanity. Family members, friends, neighbors, newspaper reporters, and coroners all searched for a root cause for deaths by suicide, something they did not always do in other death investigations, particularly deaths caused by alcohol or drug use or natural deaths. ${ }^{22}$

In their verdicts, coroners distinguished between men and women whom they understood to be insane and those who did not. These understandings were largely based on marital status, especially for women. Unmarried men and women were less likely receive qualified verdicts from investigating coroners than their married counterparts, as were married men who abused their wives or children because they violated family norms and were less likely to have sympathetic relatives to testify on their behalf. Even in cases in which there was evidence that their suicides were impulsive decisions and/or that they had a history of mental illness, coroners did not determine that these men and women suffered from insanity or temporary insanity. Coroners also did not grant

${ }^{22}$ See also: Carrie Kuhnle Inquest, July 5, 1885, Case No. 174, Folder 44, Box 43 (Missouri State Archives microfilm roll C31283), St. Louis City Office of the Coroner-Inquests 1845-1900, Missouri State Archives, Jefferson City, Missouri; Johanna Toelke Inquest, July 9, 1881 Case No. 209, Folder 10, Box 26 (Missouri State Archives microfilm roll C31278), St. Louis City Office of the Coroner-Inquests 1845-1900, Missouri State Archives, Jefferson City, Missouri; Emma C. Tuggy Inquest, July 21, 1881, Case No. 268, Folder 69, Box 26 (Missouri State Archives microfilm roll C31278), St. Louis City Office of the Coroner-Inquests 1845-1900, Missouri State Archives, Jefferson City, Missouri. 
qualified verdicts to women who worked as prostitutes, again because their reputations

mattered as much as - if not more than — the circumstances surrounding their deaths.

Finally, most unmarried men who received qualified verdicts had family members who

told the coroners that these men had a history of insanity. ${ }^{23}$

Estelle Johnson was not the only woman to receive a verdict of suicide caused by

insanity; in fact, all mothers who died by suicide in this study received verdicts of

insanity or temporary insanity. The investigation into and interpretation of her death

illustrates several themes in this chapter: relatives and the coroner attributed her suicide

to melancholy and a family crisis of some kind (in her case, losing a baby), repeated

attempts to commit suicide, and efforts by her family to stop her. The evidence indicates

that losing her ninth child triggered a mental illness from which Estelle Johnson did not

${ }^{23}$ Howard I. Kushner has written foundational work about suicide, including analyses of gender, ethnicity, and immigration. He examines the cultural history of suicide, rather than its social history, and argues that experts explained suicide as a response to a fast-paced modern life. The coroners, witnesses, and press in my study did not make such arguments, however, instead often explaining suicide in terms of the family lives of these men and women. Howard I. Kushner, American Suicide (New Brunswick: Rutgers University Press, 1991); Howard I. Kushner, "Immigrant Suicide in the United States: Toward a PsychoSocial History," The Journal of Social History 18, no. 1 (Fall, 1984): 3-24; "Biochemistry, Suicide, and History: Possibilities and Problems," The Journal of Interdisciplinary History 16, no. 1 (Summer, 1985): 69-85; Howard I. Kushner, Suicide, Gender, and the Fear of Modernity in Nineteenth-Century Medical and Social Thought," Journal of Social History 26, no. 3 (Spring, 1993): 461-490; Kushner, "Women and Suicide in Historical Perspective," Signs 10, no. 3 (Spring, 1985): 37-552.

For more on suicide, see: J. Maxwell Atkinson, Discovering Suicide: Studies in the Social Organization of Sudden Death (Pittsburgh: University of Pittsburgh Press, 1978); Jennifer M. Lehmann, "Durkheim's Response to Feminism: Prescriptions for Women," Sociological Theory 8, no. 2 (Autumn, 1990): 163-187; Jennifer Lehmann, “Durkheim's Theories of Deviance and Suicide: A Feminist Reconsideration," American Journal of Sociology 100, no. 4 (Jan., 1995): 904-930; Georges Minois, History of Suicide: Voluntary Death in Western Culture. Translated by Lydia G. Cochrane (Baltimore: The Johns Hopkins University Press, 1999); Ronald M. and Stephen T. Holmes, Suicide: Theory, Practice, and Investigation (Thousand Oaks, CA: SAGE Publications, 2005); John C. Weaver and David Wright, eds., Histories of Suicide: International Perspectives on Self-Destruction in the Modern World (Toronto: University of Toronto Press, 2008); John C. Weaver, A Sadly Troubled History: The Meanings of Suicide in the Modern Age (Montreal: McGill-Queen's University Press, 2009); David Silkenat, Moments of Despair: Suicide, Divorce, and Debt in Civil War Era North Carolina (Chapel Hill: The University of North Carolina Press, 2011); Craig Thompson Friend and Lorri Glover, Death and the American South (New York: Cambridge University Press, 2014). See also Journal of Social History 46, no. 3 (2013): 612. This entire issue of Journal of Social History is devoted to a transnational history of suicide across time. 
recover, although her family tried to help her. Today, physicians and relatives might have considered her to have been suffering from postpartum depression, but in the late nineteenth century, they considered her sadness to be melancholy. ${ }^{24}$

Estelle had only a recent history of what her relatives called "mania," "melancholy," or "despondency," although her husband documented in his diary that she was frequently sick and sometimes had "the blues" over the years. She raised four children - two daughters and two sons - although she had given birth to nine children. Evidently, she maintained a warm, comfortable home, frequently shared long talks with her husband, traveled regularly, and managed household servants. Newspaper reporters described her as "open, "loving" and "the domestic wife and the best of mothers." Her husband called her his "darling little wife" who contributed to the fact that "In domestic surroundings no man was Ever more happily situated." 25

Class privilege and a loving husband could not prevent Estelle Johnson from succumbing to some kind of mental illness after the death of her two-week-old daughter in February of 1879-six months before her suicide. When she gave birth prematurely in January, she feared that her daughter would not live, even though the child was initially

${ }^{24}$ Johnson Inquest; Papers, Johnson, Charles P. (1836-1920), (Collection CA6380), The State Historical Society of Missouri, University of Missouri, Columbia, Missouri; Ralph Johnson Death Certificate; Death Certificate for Ralph Johnson, Missouri Secretary of State, http://www.sos.mo.gov/images/archives/deathcerts/1920/1920_00018750.PDF [accessed December 1, 2014]; “A Sad Death," St. Louis Post-Dispatch, Wednesday, September 3, 1879, 1; "Died," St. Louis PostDispatch, Thursday, September 4, 1879, 4; Reunited," St. Louis Daily Globe-Democrat, Thursday Morning, September 4, 1879, 8; "Suicide From Grief," New-York tribune. (New York [N.Y.]), 04 Sept. 1879. Chronicling America: Historic American Newspapers. Lib. of Congress; $<$ http://chroniclingamerica.loc.gov/lccn/sn83030214/1879-09-04/ed-1/seq-1/> [accessed December 5, 2014]. The same brief article appeared in several newspapers across the country.

25 Johnson Inquest; Charles P. Johnson Papers; “A Sad Death,” St. Louis Post-Dispatch, Wednesday, September 3, 1879, 1; “Died," St. Louis Post-Dispatch, Thursday, September 4, 1879, 4; Reunited," St. Louis Daily Globe-Democrat, Thursday Morning, September 4, 1879, 8.

Quote from Charles' 1877 diary. He referred to Estelle as his "darling little wife" in several of his diaries. 
healthy. The baby quickly became ill and did not recover, despite regular medical care in the couple's home. Estelle_ or Essie as her husband called her-became ill and despondent after the child's death; it affected her far more severely than the deaths of four previous children whom the couple had lost. She suffered from insomnia and became addicted to the opiates that physicians prescribed for her. On June 15, she attempted suicide by drinking Peruvian bark and two days later, on the couple's eighteenth wedding anniversary, took a dose of laudanum and nearly died. At the end of July, a servant warned Charles that Essie had a bottle of chloroform. ${ }^{26}$

To prevent future suicide attempts, Charles tried to encourage his wife's recovery by traveling east to visit her parents and siblings on the east coast. The trip helped her immensely and Essie was "greatly improved," yet every time she saw a baby carriage, she would become despondent again. After their return to St. Louis, Essie still felt "miserable" and in late August, drank morphine. She claimed it was to ease her misery, not a suicide attempt, but Charles was understandably concerned. The entire family and servants kept a close watch on Essie and confined her to her bedroom. On the Sunday before her death, Charles believed that his wife was feeling much better. They spent the day walking and looking at houses to buy and he felt "hopeful and buoyant again." Yet she had procured arsenic before their trip east and on September 2, managed to hide it in the folds of her dress and slip it into her tea. Her family apparently did not know that Estelle had poisoned herself until she began to show symptoms, especially vomiting, and

\footnotetext{
${ }^{26}$ Charles P. Johnson Papers. Charles makes references to her suicide attempts in her 1879 and 1881 diaries, but based on these entries, it is unclear if she attempted suicide once or twice. It is possible that it was a single attempt, but he was mistaken about the exact date in 1881, although he noted two different poisons and two different dates in his 1879 and 1881 diaries.
} 
summoned Drs. Ware and Smith at 3:00 that afternoon. Despite their efforts to treat her, Estelle Johnson died that night. ${ }^{27}$

Estelle's family immediately explained her suicide as an impulsive act caused by grief, despite her numerous suicide attempts that year. Her mother-in-law told the coroner that Estelle said: "“Ma, I am afraid I'll die this time"” and "afterwards prayed fervently, and asked to be forgiven." She said that she believed that Estelle's act was "under the impulse of the moment, and that she certainly was not in her right mind. Whenever she would see a little child, she would speak of her last child." Estelle's daughter added that the previous Sunday (when Estelle and Charles were house-hunting) that Estelle had asked Elvira, her daughter, to pray for her, "that she felt so miserable, telling us that she was anxious to get over her feeling of misery." The family probably told Coroner Hugo Auler that Estelle was a good wife and mother, a religious woman, and one who was struck with so much grief that she was temporarily insane not only because they believed it to be true, but also because they hoped to reduce the stigma of her suicide and to garner sympathy. It worked. Coroner Hugo Auler determined that she died from suicide because of a "mental aberration, caused by grief at the death of her child." The family tried to cure her of her postpartum grief themselves with supervision and a trip east, but to no avail. Perhaps her class position and local prominence and/or the fact that psychology was in its infancy in 1879 prevented them from seeking other treatment—such as at St. Vincent's Insane Asylum. Estelle's family sought to contain

${ }^{27}$ Johnson Inquest; Charles P. Johnson Papers; Reunited," St. Louis Daily Globe-Democrat, Thursday Morning, September 4, 1879, 8. The quotes are from Charles' 1879 diary. It is well-known today among psychologists that feeling happy is often a sign of suicidal planning. 
and cure her mental illness and, when they could not, sought to explain and justify her suicide. ${ }^{28}$

Estelle Johnson was not the only member of her family to die by suicide; her youngest son did as well. Estelle's and Charles' youngest son, Ralph, who was seven years old when his mother died, struggled as an adult. He married and worked as a stock broker for many years, but he and his wife, Alice Maude, separated for some time. Ralph lived with his sister, Elvira, and her family in New Jersey. By 1920, the two were living together once more and Ralph had a new position as the Financial Editor for the St. Louis Post-Dispatch. Despite the appearance of success, the forty-six-year-old committed suicide on April 10, 1920 by slashing his throat with a razor. He committed suicide just one month before his father passed away at age eighty-four. ${ }^{29}$

The marriage and family life of Henry and Catharina Lielich was quite different from that of Charles and Estelle Johnson, yet Catharina also committed suicide and also received a qualified verdict from the coroner, sympathy from witnesses, and compassionate reports from the St. Louis press. Lielich's son also later committed suicide, although he murdered his wife first. Like Estelle Johnson, friends, relatives, and

${ }^{28}$ All quotes are from the Johnson Inquest. Charles married twice after Estelle died but he mourned for about two years, writing about her constantly in his diaries. Charles P. Johnson Papers; Ancestry.com. Missouri Marriage Records, 1805-2002 [database on-line]. Provo, UT, USA: Ancestry.com Operations, Inc., 2007 [accessed December 5, 2014]; Ancestry.com.

${ }^{29}$ Ancestry.com, 1900 United States Federal Census [database on-line], Provo, UT, USA: Ancestry.com Operations Inc, 2004 [accessed December 5, 2014]; Ancestry.com, 1910 United States Federal Census [database on-line]. Provo, UT, USA: Ancestry.com Operations Inc, 2006 [accessed December 5, 2014]; Ancestry.com, 1920 United States Federal Census [database on-line], Provo, UT, USA: Ancestry.com Operations Inc, 2010 [accessed December 5, 2014]; St. Louis Genealogical Society, comp., St. Louis City Death Records, 1850-1902 [database on-line], Provo, UT, USA: Ancestry.com Operations Inc, 2001 [accessed December 5, 2014]. 
newspaper reporters explained Catharina's suicide, but in her case, they blamed an abusive, neglectful husband and poverty rather than grief. $^{30}$

On the evening of June 13, 1880, after a day of drinking, Catharina Lielich cared for her six-year-old son, Gottlieb, before she took her own life. Her husband, Henry, and oldest son, Conrad, were away from home seeking harvesting work in Illinois and her oldest daughter, Lizzie, worked nearby as a servant. Lielich drank beer most of that day and complained to her neighbor about her abusive husband and her struggles to make ends meet. That night, after waiting until Gottlieb fell asleep, Lielich threw herself into a well in the backyard of her rented room in a boardinghouse. At 4:30 the next morning, Edward was awakened by Gottlieb's crying, and he told the man that his mother had left when he was asleep. He told a neighbor that he heard a splash of water sometime in the night, prompting the neighbor and police to search the cistern. They eventually found the body at the bottom of the well. After hearing the testimony of four witnesses, Coroner Hugo Auler rendered his verdict of suicide, but qualified his verdict by blaming her husband: "Also that ill treatment by her husband was the cause which drove her to the act." Although witnesses testified that Lielich's husband beat and threatened her, they also told the coroner that she had been drinking all day, which was evidently unusual for her. But the verdict did not mention Catharina's intoxication, likely because Coroner

\footnotetext{
${ }^{30}$ Johnson Inquest; “A Sad Death,” St. Louis Post-Dispatch, Wednesday, September 3, 1879, 1; "Died," St. Louis Post-Dispatch, Thursday, September 4, 1879, 4; Reunited," St. Louis Daily GlobeDemocrat, Thursday Morning, September 4, 1879, 8; Catherina Lielich Inquest, June 14, 1880, Case No. 2077, Folder 28, Box 22 (Missouri State Archives microfilm roll C31280), St. Louis City Office of the Coroner-Inquests 1845-1900, Missouri State Archives, Jefferson City, Missouri; "Suicide of the Mother of a Family, Caused by Poverty and Hunger," St. Louis Daily Globe-Democrat, Tuesday Morning, June 15, 1880, 4.
} 
Auler sympathized with Lielich. Newspapers concurred that an abusive husband, in addition to poverty, drove Catherina Lielich to take her own life. ${ }^{31}$

In addition to receiving qualified verdicts from investigating coroners, Estelle Johnson and Catharina Lielich share one other similarity that is unique among the cases in this chapter: they had sons who later committed suicide. Ralph Johnson died by suicide decades after his mother's death, but Gottlieb Lielich had other victims as well. Gottlieb Lielich shot himself on July 10, 1928, after murdering his estranged wife in an apparent premeditated murder-suicide. He also shot her son, who survived. Newspaper reporters made no mention of his mother's suicide, probably because they were not aware of her death nearly fifty years earlier. Although Estelle Johnson and Catharina Lielich had very different lives and family relationships, they both committed suicide and both had sons who committed suicide as well. They appear to be the only cases in which the children of individuals who committed suicide later went on to kill themselves and/or others. ${ }^{32}$

Like mothers and wives who committed suicide, coroners rendered qualified verdicts in cases of husbands and fathers who died by suicide, but only for those men whom they understood to be good providers and protectors. Relatives, friends, coroners, and the press explained the suicides of these men in terms of their gender and family

\footnotetext{
${ }^{31}$ Lielich Inquest; "Suicide of the Mother of a Family, Caused by Poverty and Hunger," St. Louis Daily Globe-Democrat, Tuesday Morning, June 15, 1880, 4.

${ }^{32}$ Man Dies by Own Hand After Killing Estranged Wife," St. Louis Daily Globe-Democrat, Tuesday Morning, July 10, 1928, 3; "Man Kills Wife, Shoots Her Son, Tries to End Life," St. Louis PostDispatch, Monday, July 9, 1928, 1; Gottlieb is a lodger in 1910 and listed as divorced in the 1920 census. Ancestry.com. 1910 United States Federal Census [database on-line]. Provo, UT, USA: Ancestry.com Operations Inc, 2006 [accessed December 10, 2014]; Ancestry.com. 1920 United States Federal Census [database on-line]. Provo, UT, USA: Ancestry.com Operations Inc, 2010. Images reproduced by FamilySearch [accessed December 10, 2014].

A future research project will determine how common it was for the children of people who died by suicide to later die by suicide or other violent deaths.
} 
relationships, as they did with mothers, primarily a loss of work. Despite these similar explanations for most men who died by suicide, coroners only rendered qualified verdicts in some cases — not for men who abused their wives or children or drank frequently.

For instance, although Franz Kurrus evidently took his own life as an impulsive act, perhaps because he lost his job, Coroner Sylvester L. Nidelet did not determine that his suicide was an act of temporary insanity. Kurrus was a man who apparently drank heavily and beat his wife, making him an unsympathetic figure despite his recent loss of work and evidence that he was a loving father. On October 28, 1884, Kurrus sat down at the dining room table and wrote a letter to his brothers asking them to care for his six children, being sure to detail his life insurance policies. He did not trust his wife, as he asked his brothers to care for his children from both marriages - not just the three children from his first marriage, which ended when his wife died. He intended that his second wife would not raise their children because he claimed that she had "swindled" him and had had an affair. The couple especially fought after Kurrus lost his brewing business, which prompted him to drink heavily and also forced the family to move frequently due to poverty. The family was about to be evicted from their latest home when Kurrus died by suicide. As he wrote to his brothers, Kurrus also wrote a letter to his children asking them to forgive him for taking his life. He then stood up, went to the bedroom and grabbed his revolver. When his wife begged him "to do nothing rash," he threatened to shoot her. Kurrus returned to the dining room, kissed his children and told them goodbye, then went into the front room and shot himself in the head. ${ }^{33}$

${ }^{33}$ Franz H. Kurrus Inquest, October 29, 1884, Case No. 1294, Folder 95, Box 40 (Missouri State Archives microfilm roll C31282 and 31308), St. Louis City Office of the Coroner-Inquests 1845-1900, Missouri State Archives, Jefferson City, Missouri. There is evidence that she may have had an affair. Seven months after Franz's death, she gave birth to a daughter, Josephine, a child with whom she was 
Although his act was evidently committed on impulse and could have been considered an act of temporary insanity, Coroner S.L. Nidelet rendered a suicide verdict without a qualifying statement for two probable reasons. First, Kurrus deviated from the ideal male role as a breadwinner and protector. Second, although his wife and oldest son made statements about his heavy drinking, previous suicide threats, recent loss of job, and violence toward his wife, they made no claims that Kurrus was insane (although one could arguably infer this from his previous threats). Newspaper reporters wrote brief, unsympathetic accounts of his death, although they did offer explanations for his suicide. One attributed his suicide to his loss of his job as a cooper in a brewery, while the other simply mentioned his death and the explanation he gave — having been swindled by his wife. His case differs from Johnson's and Lielich's in part because of his unqualified verdict and also because he garnered little sympathy from witnesses or newspaper reporters. $^{34}$

In contrast to the verdict in the death of Franz Kurrus family, Christian Stumpf received a qualified verdict and sympathy from neighbors, relatives, and the press, even though, he, too, shot himself, also apparently due to a loss of employment. Unlike Kurrus, Stumpf seldom drank, apparently provided well for his wife and treated her

pregnant when her husband committed suicide. However, she had two more children in 1888 and 1892 , both sons to whom she gave the Kurrus surname, but could not have been Franz's sons. William and Leonard Kurrus' paternity remains unknown. Matt McCune is still researching this case. Death Record for Friedrika Kurrus, Ancestry.com. Missouri, Death Records, 1834-1910 [database on-line]. Provo, UT, USA: Ancestry.com Operations, Inc., 2008 [accessed December 10, 2014; Kurrus, Friederika, St. Louis City Wills, St. Louis, Missouri, Vol. K2, p. 539, SLCL film CIWI-15, FHL film 1405582. Kurrus, Friederika, St. Louis City Wills, St. Louis, Missouri, Vol. K2, p. 539, SLCL film CIWI-15, FHL film 1405582; Ancestry.com. Missouri, Death Records, 1834-1910 [database on-line]. Provo, UT, USA: Ancestry.com Operations, Inc., 2008 [accessed December 10, 2014].

${ }^{34}$ Kurrus Inquest; “A Cooper's Suicide," in “Coroner's Cases,” St. Louis Globe-Democrat, Wednesday Morning, October 29, 1884, 12; "Why He Killed Himself," St. Louis Post-Dispatch, Wednesday, October 29, 1884. 
kindly, and had no children. Christian worked as a carpenter, but had been "out of business" recently, according to his wife. She claimed that he had also begun to show signs of "derangement" about six weeks before his death, although she could not find a reason for his mental illness and told Coroner Hugo Auler that there was no history of insanity in his family. She wanted to call a doctor, but her husband insisted that she did not, "saying that his illness could not be cured." Not only did he not get better, but he also could not find more work. On the afternoon of February 9, 1880, Stumpf suggested that his wife get out of the house for a bit and take a walk, which she did. When she returned, she found that her husband had shot himself in the head. At least in part because of his wife's testimony, the coroner added to the suicide verdict: "And that said deed was done while deceased was in a deranged state of mind." ${ }^{35}$

Although the newspapers made only brief reports of Franz Kurrus' death, the Globe-Democrat wrote a lengthy article about Stumpf's suicide because he was a more sympathetic figure than was Kurrus. The reporter noted that the German-born Stumpf "had a large circle of relatives and friends." Neighbors had noticed that he was acting strangely for the past few weeks and were not surprised to learn of his suicide, although they were upset. Because Stumpf was perceived to be a good man, the reporter devoted much space to describing his "neat" and "cozy" house in a quiet neighborhood, whose decorations illustrated that he was part of "a well-to-do German family of the middleclass of life." ${ }^{36}$

${ }^{35}$ Christian Stemipf Inquest, February 10, 1880, Case No. 1856, Folder 87, Box 20 (Missouri State Archives microfilm roll C31276), St. Louis City Office of the Coroner-Inquests 1845-1900, Missouri State Archives, Jefferson City, Missouri. Although his name is recorded as "Stemipf," subsequent research indicates that his name was "Stumpf."

36 “A Deliberate Suicide," St. Louis Globe-Democrat, Tuesday Morning, February 10, 1880, 8; Stemipf Inquest; 1860, 1870, and 1880 United States Federal Census [database on-line]. Provo, UT, USA: 
The final case of a man who was a husband and/or father differs dramatically from every other case in this chapter because the husband who took his own life evidently did so to avoid charges of child molestation. The investigation into his death illuminates a form of violence almost never seen in the records: sexual violence against a child. Sophonias Edelmann, a German-born stonemason who was married with no children, was accused by his best friend, George Falchen, of "taking improper liberties" with his eight-year-old daughter, Minnie in September of 1885. Sophonias and George were close and many assumed that Sophonias took an interest in George's daughters because he and his wife, Framaska, had no children of their own. ${ }^{37}$ Newspaper accounts claimed that his intentions were sinister, however, and reported that he lured the young girl into some willow trees while taking a stroll and "outraged" and "attempted to assault" the young girl. Minnie and her sister had stayed with the Edelmanns for five weeks that past summer, and this was when the assault occurred. He evidently sexually assaulted her, but stopped short of rape, and then bought her some candy and asked her to promise not to tell anyone. Minnie kept quiet until November when her mother learned of the attack and she told her husband shortly thereafter. Falchen spoke to a police officer about pursuing charges, although he did not reveal Edelmann's name. He also confronted Edelmann and evidently his reaction convinced him that Minnie's accusations

\footnotetext{
Ancestry.com Operations Inc, 2002 [accessed December 10, 2014. No marriage record can be found for Louisa nor can census records after Christian's death.

${ }^{37}$ Sophonias Edelmann Inquest, November 17, 1885, Case No. 499, Folder 188, Box 41 (Missouri State Archives microfilm roll C31282), St. Louis City Office of the Coroner-Inquests 1845-1900, Missouri State Archives, Jefferson City, Missouri; Scared to Death," St. Louis Post-Dispatch, Monday, November 16, 1885, 7; "Shamed Into Suicide," St. Louis Daily Globe-Democrat, Tuesday Morning, November 17, 1885, 8.
} 
were true. Reporters claimed that Falchen planned to take Minnie to a doctor that day, but subsequent events made charges unnecessary. ${ }^{38}$

The inquest tells a different story than the newspapers because Edelmann's wife, Framaska, told the coroner that her husband was being blackmailed by Falchen. Falchen, Edelmann said, insisted that Edelmann pay him fifty dollars to avoid charges of “improper liberties," and he desperately tried to raise the money, but could not. Newspaper accounts report that Edelmann sought to bribe Falchen in hopes of avoiding charges. While the truth of the bribery accusations are unknown, it is known that he asked friends for "hush money for some scandal between himself and Falchen." 39

Although the details differ, what is known is that he was accused of sexually assaulting eight-year-old Minnie and when he could not raise "hush money," he threatened and attempted to commit suicide and finally succeeded by hanging himself with a clothesline. Before he died, he wrote a letter to his wife explaining his act, a letter for the members of the Forresters' lodge, and a letter to Mrs. Falchen, Minnie's mother. Two of those letters are included in the inquest and evidently include a hastily written will and a letter to Mrs. Falchen. He did not confess to the crime in his letters. The St. Louis Post-Dispatch reported that in the letter to Minnie's mother, he claimed that he was not to blame and that "the little girl had led him on," but in fact, he did not act on her supposed efforts to seduce him. ${ }^{40}$ Both the Post-Dispatch and the Globe-Democrat concluded that Edelmann was guilty of the crime. Since the details of the assault in the

38 Shamed Into Suicide," St. Louis Daily Globe-Democrat, Tuesday Morning, November 17, 1885, 8; “Scared to Death," St. Louis Post-Dispatch, Monday, November 16, 1885, 7; Edelmann Inquest.

Accounts differ in how her mother learned of the sexual assault - either Minnie told her or she told another relative first.

${ }^{39}$ Edelmann Inquest.

40 "Scared to Death," St. Louis Post-Dispatch, Monday, November 16, 1885, 7. 
newspapers and the inquest match, he quite likely did molest the girls, although the fear of arrest and the accusation of the crime could also have been enough to prompt him to take his own life. ${ }^{41}$

The description that Edelmann's wife gave of his suicide makes it sound as if it were a rash act, yet the coroner did not qualify his verdict by claiming it was an act of temporary insanity. Framaska prevented one suicide attempt by her husband just days before his death, but his second attempt, while she was next door for a few minutes, was successful. Not only was there no history of mental illness, but Edelmann was accused of a horrific crime. Even the most thorough and often sympathetic coroner, Deputy Coroner Thomas Hennessy, evidently did not sympathize with the deceased. ${ }^{42}$

Men and, especially, women who were unmarried were less likely to receive a qualified verdict than were their married counterparts, even though, in some cases, they garnered the sympathy of witnesses and reporters. Part of the reason that unmarried men were more likely to receive qualified verdicts is because they had better reputations than did the unmarried women in this chapter. Only two unmarried women are featured in this sample and one worked as a prostitute. The other young woman apparently had a good reputation and it is unknown why the coroner did not render a qualified verdict in her case. Even though they had family members and friends to testify before the coroner,

41 Edelmann Inquest; Shamed Into Suicide," St. Louis Daily Globe-Democrat, Tuesday Morning, November 17, 1885, 8; "Scared to Death," St. Louis Post-Dispatch, Monday, November 16, $1885,7$.

42 Thomas Hennessy investigated several cases in my master's thesis and he left some of the most thorough records. Sarah Lirley McCune, "With the Intention of Destroying her Life" Women, Suicide, and the Limits of Respectability in St. Louis, Missouri, 1875 to 1900," (Columbia, Missouri: University of Missouri-Columbia, 2012). 
their occupations tarnished their reputations to the investigating coroners and the general public. $^{43}$

Although coroners did not determine that the unmarried women in this chapter who died by suicide were insane, even temporarily, they sometimes gained sympathy for their deaths and even efforts to understand their motives, such as in the death of Mary Fitzgerald Ware, alias Frankie Sturgis. Ware worked as a prostitute, but garnered sympathy from a local newspaper reporter because she had been abandoned by her husband. The twenty-two-year-old had lived in several brothels along Eleventh Street for several years and evidently worked as a prostitute when she married August Ware about seven months before her death. The marriage was short-lived and newspaper accounts claimed that August abandoned Mary and left the city. Mary began a relationship with another man, George Sturgis, and she took his surname as part of her alias when she began to work at Laura Le Bousquet's brothel a few months before her death. A reporter for the Globe-Democrat claimed that her husband returned to St. Louis, but refused to renew his relationship with Mary, prompting her despondency. The Globe-Democrat reporter concluded that Ware took her own life because she had been abandoned by her husband, which was also the reason that they claimed that she chose the "wayward" path of prostitution. While this was a common explanation for suicide in the late nineteenth century, it was untrue in Ware's case and probably many others. ${ }^{44}$

\footnotetext{
${ }^{43}$ No qualified verdicts for women who worked as prostitutes were found in an earlier study, either. See Chapter One of: Sarah Lirley McCune, "With the Intention of Destroying her Life" Women, Suicide, and the Limits of Respectability in St. Louis, Missouri, 1875 to 1900," (Columbia, Missouri: University of Missouri-Columbia, 2012).

${ }^{44}$ Franke Sturgis Inquest, May 8, 1883, Case No. 83, Folder 82, Box 33 (Missouri State Archives microfilm roll C31280), St. Louis City Office of the Coroner-Inquests 1845-1900, Missouri State Archives, Jefferson City, Missouri; Kushner, "Gender and Suicide in Historical Perspective," 469; Snyder, "What Historians Talk About," 667; "The End of a Bad Life," St. Louis Daily Globe-Democrat, Tuesday
} 
The coroner's inquest reveals the circumstances leading up to her suicide as well as the alleged reason that Ware committed suicide—-because she believed that she gained nothing from the money she made, not because of a lost love. She did appear to be especially distressed in the days before her death, but the inquest reveals no evidence that this was because her husband rejected her. Ella Brown and Jennie Johnson, a resident and housekeeper of the brothel, respectively, told Coroner Sylvester L. Nidelet that Mary had been drinking heavily for several days. She even spent the entire day in bed on the day that she took her life. Ella Brown, a fellow brothel resident, heard her weeping and when she asked Ware what the problem was she told her that she had taken morphine. She asked Ella to be present when she died and selected the clothes she wanted to be buried in. When Ella asked why she killed herself, "she replied she was tired of \& disgusted with the life she was leading as she made a great deal of money \& derived no benefit from it.” Ella sent for Dr. Henry B. Dwelle and he attempted to save Ware's life, but it was too late. Ware did commit suicide because she was upset and evidently tired of her lifestyle, but not because she was weary of working as a prostitute or because her husband rejected her, as newspaper reporters claimed. Coroner Nidelet did not render a verdict of insanity or temporary insanity in her case. ${ }^{45}$

Few women who worked as prostitutes gained sympathy from newspaper reporters, but Ware did because they believed that she had been led to the path of prostitution by her husband. ${ }^{46}$ She also had family members who testified before the

Morning, May 8, 1883, 4; Unknown Title, Daily Evening Bulletin (Maysville, Kentucky), 1883, [Kentuckiana Digital Library] [accessed December 30 2014].

${ }^{45}$ Sturgis Inquest.

${ }^{46}$ Sturgis Inquest; See, for example, two cases from Lirley McCune, "“With the Intention of Destroying her Life:"” Mantie A. Reader Inquest, January 1, 1886 Case No. 582, Folder 75, Box 45, (Missouri State Archives microfilm roll C31283), St. Louis City Office of the Coroner-Inquests 18451900, Missouri State Archives, Jefferson City, Missouri; Lucy Baird Inquest, July 10, 1898, Case No. 302, 
coroner and grieved over her remains, something that many women who worked as prostitutes did not have. Newspaper reporters lamented her suicide, but rejected the reason she gave for her death. The Globe-Democrat selectively quoted Ella Brown as saying "she was tired of the kind of life she was leading," making no reference to her remark about gaining no value from the money she earned. Reporters also ignored (or were unaware of) the fact that Ware had been living in various brothels for several years, including moving in and out of Laura Le Bousquet's "mansion." Addressing the reason that Mary gave for her suicide would have depicted a more accurate image of the deceased, but one who would be less sympathetic and would not fit the popular "seduce and abandonment" narrative popular in literature and the press at the time. Despite the sympathy from the Globe-Democrat reporter and testimony of Mary Ware's family in her inquest, Coroner Nidelet did not render a qualified verdict in her case, however. ${ }^{47}$

The June 1880, suicide of Lizzie Studler is similar to that of Mary Ware because friends, relatives, and newspaper reporters attributed her suicide to a lost love, but Deputy Coroner Frank R. O’Neil did not render a qualified verdict in her case, either, perhaps because none of her relatives gave evidence of insanity. The twenty-year-old had worked as a domestic servant for several years and had recently taken a new position as a seamstress. Like other men and women who committed suicide, Studler threatened to kill herself before she did so, but her father believed she was joking. Instead of trying to prevent her suicide, he joined in her "joke" three weeks before her death, telling her that

Folder 103, Box 110 (Missouri State Archives microfilm roll C31304), St. Louis City Office of the Coroner-Inquests 1845-1900, Missouri State Archives, Jefferson City, Missouri.

47 Sturgis Inquest; “The End of a Bad Life," St. Louis Daily Globe-Democrat, Tuesday Morning, May 8, 1883, 4; Kushner, "Gender and Suicide in Historical Perspective," 469; Snyder, "What Historians Talk About," 667. 
he, too, would drown himself in the river and would even tie a stone around her neck to ensure that she drowned. John Studler, Lizzie's father, not only did not know much about his daughter's state of mind, but he also knew very little about his daughter's relationships. Lizzie's brother revealed that two to three weeks before her suicide, she had broken up with a longtime beau in hopes of reuniting with a previous boyfriend. The young man deceived her, however, and she ended up alone. In the days before her death, she seemed troubled. She gave her eleven-year-old sister, Louisa, her rings and other possessions and told her that if she did not see her the next morning, she would never see her again. That evening, she threw herself into a neighbor's well. ${ }^{48}$

As was common for respectable men and women, relatives and newspaper reporters attributed Studler's suicide to family relationships, in this case, to despondency over losing her boyfriend. Yet another possible cause was revealed in the coroner's report and one newspaper article—conflicts with her parents. The coroner asked several questions about Studler's home life and her brother assured investigators that his sister was not treated harshly and had a pleasant home. The Post-Dispatch offered a different account, claiming that "bad treatment and misfortune in love" led to her suicide. The reporter, citing police accounts, claimed that her father treated her harshly and before she left to commit suicide, she left a "note on her father's counter, saying that she was tired of living with drunken parents, and that she would not be seen again." Neighbors told the reporter that Lizzie was somewhat "sensitive" and that the neighbors knew that her father treated her poorly. Considering his unusual joke about her suicide threat and the

${ }^{48}$ Lizzie Studler Inquest, June 26, 1880, Case No. 2097, Folder 48, Box 22 (Missouri State Archives microfilm roll C31276), St. Louis City Office of the Coroner-Inquests 1845-1900, Missouri State Archives, Jefferson City, Missouri. 
coroner's questions about her family life, the Post-Dispatch reporter could have been correct, but the Globe-Democrat did not publish a similar account. Instead, the GlobeDemocrat reporter attributed her suicide to lost love and claimed that her father said, "under much mental and physical excitement" that "He had 'loved that d_d girl."” While Studler's motivations cannot be known, what is evident is that people sought to understand why she committed suicide and created explanations based on the evidence they had available. She may have believed that she had lost the chance to marry or felt regret about ending the relationship with one man in hopes of gaining another.

Interestingly, newspaper reporters and her family did not question that a breakup would be enough motivation for Lizzie to kill herself. ${ }^{49}$

Unmarried men, like unmarried women, received qualified verdicts from the coroner only if they had relatives who testified that they were insane and had good reputations, as illustrated by two cases. Frank Bingham was separated from his wife and young daughter and lived in a boardinghouse, all of which made him isolated from his family and less-than-respectable. When he died by suicide, he did not receive a verdict of insanity. In contrast, Jerome Buckley was a young, unmarried man whose parents told the coroner that he suffered from a religious mania. Buckley received a qualified verdict from the coroner because of his parents' testimony that he was insane, but he gained more sympathy from the coroner and others because he did not deviate from the male gender norm, as Bingham did.

49 "The Surcease of Sorrow," St. Louis Post-Dispatch, Saturday, June 26, 1880, 1; "Dead for Love," St. Louis Daily Globe-Democrat, Sunday Morning, June 27, 1880, 8; Studler Inquest; Ancestry.com. Missouri, Death Records, 1834-1910 [database on-line]. Provo, UT, USA: Ancestry.com Operations, Inc., 2008; 1880 United States Federal Census [database on-line]. Provo, UT, USA: Ancestry.com Operations Inc, 2002 [accessed December 10, 2014]. 
Frank Bingham died surrounded by strangers in a lodging house on Spruce street and had no loved ones to try to explain his sudden suicide to Coroner Sylvester Nidelet. Fellow lodgers found his body in his bed on the afternoon of November 23, 1885. He had poisoned himself with laudanum and left instructions as to how to lay out his body for burial. The coroner evidently could find no relatives to interview, but spoke to Bingham's employer and the lodging house owner. Frank and his wife had lived apart for some time, due to frequent disagreements and Bingham's drinking, although Frank evidently tried to reconcile several times. Ten days before his death, Frank went to his employer, H.C. Fuller, and quit his job after a drinking spree. No one who spoke to the coroner knew Bingham well; they did not even know his name as he used the alias Frank or Jim Edwards. No one speculated about a motive for his suicide, with the exception of his former employer and newspaper reporters who attributed it to his marital troubles. ${ }^{50}$

Although Bingham isolated himself from his wife, daughter, and employer, perhaps because of his drinking, he evidently maintained contact with his mother. A reporter for the Globe-Democrat wrote that Bingham asked someone to telegraph his mother to notify her that he had failed to find his father. Bingham had apparently been traveling in search of his father, but with no success. His father wrote him two letters afterward, which he kept in a trunk, but were not included in the inquest or the newspaper report. The reporter also described a statement that Bingham made in his suicide note, "God help my little girl," referring to his young daughter. The Globe-Democrat reporter

${ }^{50}$ Frank Bingham Inquest, November 25, 1885, Case No. 513, Folder 6, Box 45 (Missouri State Archives microfilm roll C31283), St. Louis City Office of the Coroner-Inquests 1845-1900, Missouri State Archives, Jefferson City, Missouri; "The Will of a Suicide," St. Louis Daily Globe-Democrat, Tuesday Morning, November 24, 1885, 12; "Driven From Home," St. Louis Post-Dispatch, Tuesday, November 24, 1885, 2. 
did not speculate as to why Frank committed suicide, but a reporter for the Post-Dispatch concluded that it was because he had been "driven from home," blaming his wife for their separation. Yet unlike the women in this chapter who supposedly committed suicide because of lost loves, the reporter only mentioned this reason in his title, but did not elaborate on it. Neither reporter claimed that strained family relations with his father, wife, or daughter caused his suicide. ${ }^{51}$

The suicide of Jerome Buckley is quite different from that of Frank Bingham because the investigating coroner rendered a verdict of suicide caused by insanity, drawing on statements from his parents to make this determination. His relatives and Deputy Coroner George W. Peck concluded that he threw himself into the Missouri river on the evening May 8, 1883, because he was of "unsound mind." Buckley threatened to commit suicide before he succeeded in his threats. Once, he threatened to drown himself and on another occasion, he bought a pistol with the apparent intention of shooting himself. His father told the coroner that for the past few years Jerome had been physically healthy, but his mind was "weakened" and "troubled" to the point that his father believed that he was incapable of caring for himself. The twenty-two-year-old had no job, but sometimes helped his father at home. He was particularly obsessed with religion, his father said, and "his mind was dwelling almost constantly on the subject \& he seemed puzzled and confused by it." His son also drank and used "stimulants \& he appeared insane when he did." Buckley was evidently intoxicated on the day that he died. His father intended to "take care of him," but he could not because Buckley told his family "he would leave us all" and ran toward the river, his father quickly behind him.

${ }^{51}$ Bingham Inquest; "The Will of a Suicide," St. Louis Daily Globe-Democrat, Tuesday Morning, November 24, 1885, 12; “Driven From Home," St. Louis Post-Dispatch, Tuesday, November 24, 1885, 2. 
His father was too late and caught up with his son when he was in the river, warning him that he could not swim with his clothes on. Buckley made swimming motions, then dove into the water. He floated briefly and then he sank. His body washed up six days later, on May $14,1883 .{ }^{52}$

Although Buckley was evidently drunk when he died by suicide, Deputy Coroner George W. Peck did not record this in his verdict, instead claiming that he was insane, or of "unsound mind." Buckley came from a middle-class family and his parents told the investigating coroner that they believed that he suffered from insanity. Of course, his parents also told the coroner that their son drank regularly, but Peck did not note this in his verdict, likely because the family was respectable. His father in particular seemed to take responsibility for caring for his son when he was under the influence of alcohol. The testimony from Buckley's father suggests that Buckley's behavior became particularly erratic after he drank, but the young man also could not care for himself and seemed "troubled" when he was sober. Still, Buckley's death resembles those that will be examined in Chapter Two - deaths caused by alcohol and/or drugs. In those cases, however, the investigating coroners mentioned intoxication or alcoholism in their verdicts and only considered one supposed alcoholic to suffer from insanity. ${ }^{53}$

Jerome Buckley was just one person who died by suicide who received a verdict of insanity from the investigating coroner because his family testified that he suffered from a mental illness and because he had a good reputation. Coroners relied on the

52 Jerome Perry Buckley Inquest, May 14, 1883, Case No. 96, Folder 95, Box 26 (Missouri State Archives microfilm roll C31280), St. Louis City Office of the Coroner-Inquests 1845-1900, Missouri State Archives, Jefferson City, Missouri.

${ }^{53}$ Buckley Inquest. His father worked as a lumber contractor and the family had a hired worker or servant as well. U.S. Bureau of the Census, 1880, ancestry.com [accessed July 16, 2017]. 
testimony of family members, neighbors, and, more rarely, physicians to understand why these men and women took their own lives. The explanations given by witnesses and newspaper reporters were often insanity, but only in cases in which these men and women had family members who believed their loved ones to be insane and for men and women who were understood to be respectable men and women. A verdict of insanity softened the stigma of a suicide verdict and explained the unexpected deaths of mothers and fathers especially. They understood suicide to be the result of insanity - a nebulous term - but only for respectable men and women with families who provided testimony of "mental aberration." In the deaths of men and women who were not understood to be insane, witnesses and newspaper reporters explained these suicides to be caused by poverty, family conflicts, love turned sour, and grief. While insanity was a medical term, these cases show that when coroners determined that men and women suffered from insanity it was because of testimony from their family members, not physicians. A good reputation also mattered in terms of suicide verdicts and newspaper accounts, as will be illustrated in the next chapter of men and women who died from alcohol and/or drug use. 


\section{Chapter Two \\ Not Quite Suicide: Alcohol as a Contributor to Untimely Deaths}

On the afternoon of February 29, 1884, sixteen-year-old Michael Donahoe came home from work around midnight to his family's rented rooms in a boardinghouse. He peeked in to his mother's room before he went to bed, but he did not find her sleeping, as he expected. To his horror, Michael found that his mother was dead. He ran to get his neighbor, William Ryan, who confirmed that fifty-year-old Ann Donahoe had passed away. She lay "on the bed her arms crossed...\& head bent upon her chest. She was cold \& stiff." Ryan did not seem terribly surprised that his neighbor had died because he had heard her vomiting regularly for several days through the boardinghouse walls. Coroner Sylvester L. Nidelet came to investigate Ann's untimely death. Ryan, the neighbor, and Ann Donahoe's husband, Michael, told Coroner Nidelet that the reason that she had been so ill lately was because of a problem that she had experienced for a few years: "indulg[ing] in liquor to excess." 54

Coroner Nidelet determined that Ann Donahoe died from dipsomania, or alcohol insanity, and this, in fact, is the only verdict of dipsomania among the tens of thousands of inquests that exist for the city of St. Louis from 1840 to 1900 . Coroners rendered verdicts of "intoxication," "alcoholism," or "inebriety" when they believed that alcohol caused or contributed to a death, but Coroner Nidelet believed that Donahoe suffered from a special form of alcoholism—a "madness" alcohol. ${ }^{55}$ Unlike other forms of

\footnotetext{
${ }^{54}$ Ann Donahoe Inquest, February 2, 1884, Case No. 752, Folder 110, Box 37 (Missouri State Archives microfilm roll C31281) and Folder 258, Box 120 (Missouri State Archives microfilm roll C31308) St. Louis City Office of the Coroner-Inquests 1845-1900, Missouri State Archives, Jefferson City, Missouri. Hereafter the case will be referred to as "Donahoe Inquest."

${ }^{55}$ Sarah W. Tracy, Alcoholism in America: From Reconstruction to Prohibition (Baltimore: The
} 
habitual drunkenness, including intemperance or alcoholism, in which a person drank to excess regularly, physicians who specialized in alcohol treatment defined dipsomania differently. Medical professionals understood dipsomania to be inherited, experienced primarily by the middle and upper classes and, most importantly, a form of insanity. Ann Donahoe was a working-class Irish woman, but she was also a wife and, more importantly, a mother who had begun drinking after the death of two of her children, all of which garnered her sympathy from Coroner Nidelet. Just as coroners did when they rendered qualified verdicts in deaths by suicide, Nidelet based his ruling on testimony from Donahoe's relatives. While her neighbor judged her harshly for her intemperance, the testimony of her family, her good reputation, and her status as a middle-aged grieving mother all prompted Nidelet to render his verdict of dipsomania, a stigmatized verdict, but one more respectable than "alcoholism," or "intemperance." 56

Johns Hopkins University Press, 2005), 32. Historians and documents from the period show a consensus about the characteristics of dipsomania, although some claimed it was related to insanity, while others claimed it was a form of insanity. For instance, see: Gerry Johnstone, "From Vice to Disease? The Concepts of Dipsomania and Inebriety, 1860-1908." Social and Legal Studies 5 (1996): 37-56; Patricia E. Prestwich, "Female Alcoholism in Paris, 1870-1920: The Response of Psychiatrists and of Families," History of Psychiatry 14, no. 3 (2003): 321-336; "Dipsomania," in "Clinical Notes and Comments," The Quarterly Journal of Inebriety 4, no. 1 (Jan. 1880): 51-52; "Dipsomania and Heredity" in "Clinical Notes and Comments," The Quarterly Journal of Inebriety 10 (1888): 395-397; Norman Kerr, M.D., F.L.S., "The Treatment of Female Inebriety," "Dipsomania and Heredity" in "Clinical Notes and Comments," The Quarterly Journal of Inebriety 10 (1888): 68-76; Dr. E. Decaisne, "Dipsomania in Women," The Quarterly Journal of Inebriety 11 (1889): 247-252; "Drugs That Enslave: Words of Good Advice and Encouragement for Their Victims," St. Louis Post-Dispatch, June 2, 1889, 17; "Drunkards and Dipsomaniacs," St. Louis Post-Dispatch, May 19, 1881, 2.

${ }^{56}$ Tracy, Alcoholism in America, 32. Tracy's monograph is just one of several foundational works about alcoholism in the U.S. See also: Harry Gene Levine, "The Discovery of Addiction: Changing Conceptions of Habitual Drunkenness in America," Journal of Studies on Alcohol 39, no. 1 (1978): 143174; William J. Rorabaugh, The Alcoholic Republic: An American Tradition (New York: Oxford University Press, 1979); Mark Lender, "A Special Stigma: Women and Alcoholism in the Late $19^{\text {th }}$ and Early $20^{\text {th }}$ Centuries," in Alcohol Interventions: Historical and Sociocultural Approaches eds. David L. Strug, S. Priyadarsini, and Merton M. Hyman (New York: The Haworth Press, 1986): 41-57; Catherine Gilbert Murdock, Domesticating Drink: Women, Men and Alcohol in America, 1870-1940 (Baltimore: The Johns Hopkins University Press, 1998); Sarah W. Tracy and Caroline Jean Acker, Altering American Consciousness: the History of Alcohol and Drug Use in the United States, 1800-2000 (Amherst: University of Michigan Press, 2004); Scott C. Martin, Devil of the Domestic Sphere: Temperance, Gender, and Middle-class Ideology, 1800-1860 (DeKalb: Northern Illinois University Press, 2008). 
When contrasted with the other cases in this chapter, Ann Donahoe's case illustrates that coroners added a value judgment in addition to cause of death in their verdicts, which almost never featured an explanation of alcoholism caused by insanity as they did in many deaths by suicide. As with the other deaths in this study, the reputation of the deceased and testimony of family members shaped the death investigations and verdicts. In most of these cases, there was no question who was at fault: it was the deceased, which is part of the reason they conducted brief inquests into these deaths. In addition to Ann Donahoe, seventeen other men and women died from alcohol:

alcoholism, accidents, illnesses, and even two potential homicides. ${ }^{57}$ Three of these men and women died from drug use — some of whom used morphine or opium in addition to alcohol. As in deaths by suicide, many of the relatives and friends of those who died from alcohol use told investigating coroners that these men and women were struggling emotionally and/or financially. Some witnesses also told coroners that these men and women died after going on drinking binges, sometimes because of grief, lost jobs, or other struggles. But unlike in investigations into suicides, coroners almost never incorporated these explanations into their verdicts and did not consider these men and women to be suffering from insanity. Coroners, witnesses, and newspaper reporters understood most respectable men and women who died by suicide to be insane, at least temporarily, or have some other understandable reason for taking their own lives. In contrast, most coroners, the press, and some witnesses did not seek a reason as to why

${ }^{57}$ Eighteen cases in this study of 120 cases feature verdicts that contain the word "alcohol," with the exception of one case, in which the word is in the witness testimony, but not the verdict. Of these eighteen cases, fifteen were researched for this chapter (because three had no testimony and therefore insufficient information). The cases are organized in this chapter by cause of death (alcoholism, accidents or natural deaths with alcohol as a contributing factor, and alcohol and drugs). 
men and women died from drinking because they believed that these men and women lacked self-discipline and had made an immoral life choice.

Deaths caused by alcohol or drug use differed from deaths by suicide in another important way: the question of whether or not men and women who died from alcoholism intentionally took their own lives. Arguably, drinking oneself to death is suicide, but most Americans did not consider it to be the same. Alcohol-related deaths either from the direct effects of alcoholism, accidents that occurred while men and women were intoxicated, or because alcohol exacerbated illnesses lacked the one of the key elements of a suicide: they were not intentional deaths, although they did occur from injuries that were self-inflicted. ${ }^{58}$ Many witnesses told the coroner that their friend, relative, or acquaintance had died because of their "intemperate" or "dissipated" habits, but they did not believe that these men and women intended to kill themselves. Arguably, these individuals' habits of drinking made the inquests easy to conduct; coroners quickly gathered evidence that these men and women drank themselves to death or otherwise died from alcohol use and could therefore render verdicts with less investigation than suspected suicides. They did gather evidence quickly, but the brief inquests alone do not reveal a moral judgment: the unsympathetic, even judgmental tone of some of the witnesses and newspaper reporters and, in a few cases, possible insufficient investigations into these deaths illustrate that few, even coroners, sympathized with alcoholics.

Surprisingly, newspaper reporters almost never wrote accounts about alcoholrelated deaths, although they generally loved a sensationalistic story of a sudden death.

${ }^{58}$ Stefan Timmermans, Postmortem: How Medical Examiners Explain Suspicious Deaths (London: University of Chicago Press, 2006), 84. 
Homicides, suicides, and accidents covered the pages of the St. Louis-Globe Democrat and, to a lesser extent, the St. Louis Post-Dispatch, but they published very few articles about men and women who died because of alcohol and when they did publish stories, they were quite brief. Reporters generally judged the deceased harshly by using their stories as warnings for their readers about the dangers of alcohol. St. Louis reporters did not consider the deceased to be insane, nor did they seek a root cause for their heavy drinking. ${ }^{59}$

A double standard existed for men and women who suffered from alcoholism, making it easier and more socially acceptable for women to receive treatment for addiction to opium, morphine, or laudanum than for alcohol in the late nineteenth century. Women who drank to excess were perceived to be more dangerous than men because they were supposed to be morally superior to men and provide an appropriate example for their children. Interestingly, it seems as though these women's failure to teach their children proper behavior was a greater concern to physicians than their inability to care for their children—not to mention themselves—-because they were often intoxicated. Despite their sympathy for alcoholics, physicians who specialized in treating

${ }^{59}$ Perhaps the omission is because alcohol-related deaths were commonplace. Historian Catherine Gilbert Murdock argues that "public drunkards were a pathetic, everyday spectacle in villages and cities" across the country. Murdock, 4; "Died Drunk," in "Coroner's Cases," St. Louis Daily Globe-Democrat, Monday morning, June 28, 1880. Of the nineteen cases explored for this chapter, I searched for fifteen newspaper reports were searched for (because three cases had no testimony and were excluded). Of those, I could not find articles for six women and two men. I found newspaper accounts for two women and five men. Harry Gene Levine, "The Discovery of Addiction: Changing Conceptions of Habitual Drunkenness in America." Journal of Studies on Alcohol 39, no. 1 (1978):143-144; Katharine A. Chavigny, "Reforming Drunkards in Nineteenth-Century America: Religion, Medicine, Therapy," in Sarah W. Tracy and Caroline Jean Acker. Altering American Consciousness: the History of Alcohol and Drug Use in the United States, 1800-2000. Amherst: University of Michigan Press, 2004, 118; Levine, "The Discovery of Addiction," 143-144; Tracy and Acker, 16; Sarah W. Tracy, "Building a Boozatorium: State Medical Reform for Iowa's Inebriates, 1902-1920," in Tracy and Acker, Altering American Consciousness: the History of Alcohol and Drug Use in the United States, 1800-2000. Amherst: University of Michigan Press, 2004, 124, 134, 140; Tracy, Alcoholism in America, 230. 
alcoholism expressed concerns about women in particular because their drinking

threatened their society as a whole as well as their families. Men who drank to excess

also challenged their roles as workers, fathers, providers, and protectors, because they

were unreliable and undisciplined, but it was a drunken wife and mother who was both

more pitiful and dangerous. ${ }^{60}$

Although physicians who specialized in treating alcoholism believed that

alcoholic women were greater threats to society than were alcoholic men, inquests into their deaths show that attitudes toward alcoholic women varied, just as they did for men. ${ }^{61}$ For instance, newspaper reporters, relatives, and the investigating coroner did not condemn thirty-eight-year-old Margaret Doyle for drinking herself to death in 1880, even though she left behind several children. Of course, none of these people openly sympathized with her, either. Margaret's eight-year-old daughter, Maggie, found her

${ }^{60}$ Norman Kerr, M.D., F.L.S., "The Treatment of Female Inebriety," "Dipsomania and Heredity" in "Clinical Notes and Comments," The Quarterly Journal of Inebriety 10 (1888): 66, 69; Murdock, 4, 42, 48; Lender, "A Special Stigma, 42;" Historian Sarah Tracy points out that women generally drank less than men in the late nineteenth century, but it varied by ethnicity, while Catherine Gilbert Murdock claims that women represented only about twenty percent of all alcoholics between 1880 and 1920, although she notes that accurate numbers are impossible to determine. Tracy, Alcoholism in America, 45-46; McClellan, “"Lady Tipplers,"” in Tracy and Acker, 281; Martin, 39; Holly Berkley Fletcher, Gender and the American Temperance Movement of the Nineteenth Century (New York: Routledge, 2008), 35; Dr. E. Decaisne, "Dipsomania in Women," The Quarterly Journal of Inebriety 11 (1889): 247-252; "Dipsomania and Heredity" in "Clinical Notes and Comments," The Quarterly Journal of Inebriety 10 (1888): 395-397.

${ }^{61}$ Tracy, Alcoholism in America, 45-46, 51-52; Murdock, Domesticating Drink, 43-44; Lender, “A Special Stigma." Historian Mark Lender argues that such a stigma existed toward women alcoholics that they often hid their drinking and relied on friends and relatives to do so as well. Patricia Prestwich argues that women drank away from men, but this does not mean that they kept it a secret in her study of Paris. Lender, "A Special Stigma," 41; Prestwich, "Female Alcoholism in Paris," 330; Martin 15, 21-22; Tracy, Alcoholism in America, 45-46, 51-52; Michelle McClellan argues that alcoholic women were invisible in her essay, “'Lady Tipplers': Gendering the Modern Alcoholism Paradigm, 1933-1960" in in Sarah W. Tracy and Caroline Jean Acker, Altering American Consciousness: the History of Alcohol and Drug Use in the United States, 1800-2000 (Amherst: University of Michigan Press, 2004): 267-297. Tracy studies some of the institutions that opened between 1870 and 1920, but none admitted women. In St. Louis, most alcoholic men and women went to St. Vincent's Asylum, if they received treatment at all. Some called for a facility, though. "Badly Needed: A Sanitarium for the Treatment of Confirmed Drunkards," St. Louis Post-Dispatch, March 20, 1882, 3. An ad in the St. Louis Post-Dispatch offered treatment at a Jerseyville, IL, facility: Display Ad 2, No Title, St. Louis Post-Dispatch, June 27, 1900, 2. 
mother dead in her bed on the afternoon of June 26, 1880, after drinking a large amount of alcohol. Maggie told the coroner that her mother began drinking heavily two weeks earlier, when her father moved to St. Charles to work. Doyle's brother-in-law told the coroner that she had always "drank quite hard at intervals."62 Doyle's other relatives similarly recounted the details of her drinking without judging her harshly, but they also did not offer an excuse for her drinking. Deputy Coroner Frank R. O’Neil concluded that Doyle's death was from "the result of alcoholism."63

Despite the fact that she was a woman who binge drank, O’Neil did not decide that she was a dipsomaniac, as Coroner Nidelet did in Donahoe's case. Her reputation, fairly young age (thirty-eight) and the investigating coroner could all be reasons why she did not receive a verdict that included the word "dipsomania." Unlike Donahoe, Doyle had a reputation among her family members as someone who regularly drank to excess. Instead of trying to explain why Doyle drank heavily, her eight-year-old-daughter and her brother-in-law told O'Neil that she drank often. Doyle had lost three of her children, just as Donahoe had, but her brother-in-law stated that as a matter of fact, not as a reason that she may have drank so heavily, particularly because he added that she had been drinking more recently. Doyle's age and the ages of her children mattered, too. It was her eightyear-old daughter who found her deceased and offered the first testimony to the coroner - a young girl who still required supervision and care from her mother, unlike Donahoe's teenage son. Doyle was also only thirty-eight and still in her childbearing years, unlike many women who supposedly suffered from dipsomania, who were often

${ }^{62}$ Doyle inquest; "Died Drunk," in "Coroner's Cases," St. Louis Daily Globe-Democrat, Monday morning, June 28, 1880, 8.

${ }^{63}$ Doyle inquest. 
young women or menopausal. Finally, Deputy Coroner Frank O’Neil was not a medical doctor like Coroner Sylvester Nidelet was and was probably unfamiliar with the diagnosis of dipsomania. ${ }^{64}$

Although the press reported on Doyle's death, which they seldom did in deaths caused by alcoholism, reporters did not try to understand why she drank herself to death, unlike in cases of suicide. Reporters did not sympathize with Margaret, but they did not judge her harshly, either. They reported her case along with other coroner's cases for the day under the headline "Died Drunk." The reporter recounted many of the details of the case and noted briefly that she left behind six children and a husband. Perhaps this is because the reporter assumed that she was addicted to alcohol and/or lacked the morality or will to stop drinking. ${ }^{65}$

Like Margaret Doyle, Bridget Tracey also lived on nothing but alcohol in the days before her death, but unlike Doyle, Tracey had an underlying health issue that was overlooked by the coroner: epilepsy. Tracey’s son, Thomas, told Deputy Coroner Thomas Hennessy that his mother, a forty-year-old housekeeper, "was a hard drinker" who "was also subject to epileptic fits." Tracey's neighbor found her in her bedroom on July 6,1885 , in an unusual position: "lying on her stomach and her face against the floor." Her description makes it sound as if she half-fell out of bed before she died, perhaps because of a seizure. Deputy Coroner Thomas Hennessy interviewed two witnesses briefly before rendering his verdict of a death caused "from the effects of

${ }^{64}$ Tracy, "Building a Boozatorium," in Tracy and Acker, 134; White, William L. "The Lessons of Language: Historical Perspectives on the Rhetoric of Addiction," in Sarah W. Tracy and Caroline Jean Acker. Altering American Consciousness: the History of Alcohol and Drug Use in the United States, 18002000. Amherst: University of Michigan Press, 2004, 46. $28,1880,8$.

${ }^{65}$ Died Drunk," in "Coroner's Cases," St. Louis Daily Globe-Democrat, Monday morning, June 
alcoholism." Despite having evidence of epilepsy as a potential cause of Tracey's death, Deputy Coroner Thomas Hennessy decided that she died from alcoholism alone. ${ }^{66}$

Hennessy spoke only to Tracey's son and neighbor before rendering his verdict, indicating that he did not sympathize with her. His brief investigation was unusual because he ordinarily interviewed several witnesses to understand not just how someone died, but why. In cases of suicide, even for a young woman who was pregnant out of wedlock, Hennessy engaged in lengthy interviews in addition to examining their bodies and the location of their deaths to determine why these young women committed suicide. ${ }^{67}$ Yet in the death of Bridget Tracey, Hennessy interviewed only two witnesses and left only one page of testimony. Likewise, newspaper reporters did not write about Tracey's death at all. Despite her status as a mother, widow, and poor woman, Tracey's alcoholism rendered her disreputable and eliminated the possibility if gaining sympathy for her death, much less a search for the causes of her addiction. ${ }^{68}$

${ }^{66}$ Bridget Tracy Inquest, July 6, 1885, Case No. 180, Folder 50, Box 43 (Missouri State Archives microfilm roll C31283), St. Louis City Office of the Coroner-Inquests 1845-1900, Missouri State Archives, Jefferson City, Missouri. Although her name is recorded as "Tracy," in the inquest title, witnesses and other sources spelled her name "Tracey."

${ }^{67}$ For example, see: Lucy Grimes Boyd Inquest, February 12, 1886, Case No, 677, Folder 19, B ox 46 (Missouri State Archives microfilm roll C31284), St. Louis City Office of the Coroner-Inquests 18451900, Missouri State Archives, Jefferson City, Missouri. Hereafter the case will be referred to as Boyd Inquest; "God Pity Me," St. Louis Post-Dispatch, Saturday, February 13, 1886, 5; Annie Sophie Weigmann Inquest, July 24, 1884, Case No. 1079, Folder 79, Box 39 (Missouri State Archives microfilm roll C31282), St. Louis City Office of the Coroner-Inquests 1845-1900, Missouri State Archives, Jefferson City, Missouri. Thomas Hennessy investigated several cases in my master's thesis and he left some of the most thorough records. Sarah Lirley McCune, "With the Intention of Destroying her Life"” Women, Suicide, and the Limits of Respectability in St. Louis, Missouri, 1875 to 1900," (Columbia, Missouri: University of Missouri-Columbia, 2012).

${ }^{68}$ Americans in the nineteenth century (and other eras) often distinguished between the worthy and unworthy poor and this impacted their view of their drinking and deaths as well. Tracy, "Building a Boozatorium," in Tracy and Acker, 141. How views of the poor shaped coroner's inquests seems to be more complex, however, because many of the deaths that coroners investigated were of the poor (and friendless, according to Stephen Berry). As Berry observes, why this is the case remains to be understood. Stephen Berry, "The Historian as Death Investigator," in Weirding the War: Stories from the Civil War's Ragged Edges, Stephen Berry,ed. (Athens: University of Georgia, 2011), 183. 
Martha J. Thomas also received a brief investigation into her death by Deputy Coroner H. Praedicaw, not only because she died from alcoholism, but also because she was black. Thomas received a remarkably brief inquest, even when compared to the inquests of disreputable St. Louisans and other African Americans, likely because she drank herself to death. Like Doyle and Tracey, Martha J. Thomas had long been a hard drinker, but had been drinking even more in the days before her death. She died around 5:30 pm on April 22, 1882, her husband, William N. Thomas, told the coroner. Not much else is known about Thomas, only that she was a twenty-nine-year-old married housewife who lived on Twelfth street, a known disreputable area because it was rife with brothels and crime. After interviewing William and recording a mere two sentences of testimony, Deputy Coroner H. Praedicaw rendered his verdict: "alcoholism, at her residence." No newspapers covered Martha's death. Apparently, St. Louis reporters did not consider it to be even worth a sensational account proving stereotypes about African Americans and excessive drinking. ${ }^{69}$

Unlike Thomas, Tracey, and Doyle, the coroner who investigated the death of Ann Donahoe determined that she was insane because she was a respectable, workingclass Irish mother who had lost two of her children. The fifty-year-old housewife who died from drinking to excess on February 29, 1884 was similar to the other women and men in this study in that she drank to the point of drunkenness regularly. Unlike many other men and women who died from drinking, though, Donahoe had a family who loved

\footnotetext{
${ }^{69}$ Martha J. Thomas Inquest, April 22, 1882, Case No. 805, Folder 56, Box 29 (Missouri State Archives microfilm roll C31279), St. Louis City Office of the Coroner-Inquests 1845-1900, Missouri State Archives, Jefferson City, Missouri; McClellan, "“Lady Tipplers,"” in Tracy and Acker, 281; Joseph A. Dacus and James W. Buel commented in 1878 that although most of $12^{\text {th }}$ street represented a neighborhood rife with crime and poverty, some "respectable and worthy" people could be found there. Joseph A. Dacus and James W. Buel, A Tour of St. Louis: or, The Inside Life of a Great City (St. Louis, Missouri: Western Publishing Co., 1878), 454-455.
} 
her and gave the coroner a reason for her excessive drinking: the loss of her two children. Donahoe was not an ordinary drunk, but a grieving mother whose drinking was triggered by the death of her children. As a grieving mother who was understood to suffer from insanity, Ann Donahoe had more in common with mothers who died by suicide, such as Estelle Johnson and Catharina Lielich—at least for Coroner Sylvester Nidelet, who investigated Donahoe's death. Although family members sympathized with Donahoe, her neighbor did not. Neighbor William Ryan told Coroner S.L. Nidelet that he had spoken to Donahoe several times about her drinking, but she "laughed at me and continued in the same way." Coroner Nidelet sympathized with Donahoe and rendered a verdict of "dipsomania" instead of "alcoholism," which softened the stigma of her drinking just as adding "while laboring under temporary insanity" reduced the stigma of a suicide verdict. Despite the coroner's respect for Donahoe, St. Louis newspapers did not even print an obituary, an omission common for men and, especially, women who died from alcoholism. ${ }^{70}$

Despite this public invisibility for most women alcoholics, physicians who studied inebriates also believed, in an interesting contradiction, that women were more vulnerable to dipsomania than were men, particularly upper-class women. Physicians who treated alcoholics argued that women were particularly susceptible to dipsomania because of their biology, meaning their menstrual cycles and ability to bear children. Ann Donahoe was fifty, and while her inquest did not indicate that she had recently experienced "the change of life" (as some inquests did), it could be one reason why

${ }^{70}$ No newspaper articles could be found for Donahoe. Donahoe Inquest; US Bureau of the Census, 1880. In 1880, the family is living at another address in St. Louis and they have only their son Michael living with them. 
Coroner Nidelet believed that she had this form of alcohol insanity. Interestingly, Donahoe was one of the few working-class or poor women to suffer from what was understood as a primarily middle-and-upper class illness. Ann Donahoe was no Irish drunk, but a dipsomaniac — a stigmatized label for her drinking, but one more respectable and sympathetic than "alcoholic," "intemperate," or "drunk."71

While the coroner and her relatives sympathized with Donahoe, in general, coroners, relatives, and newspaper reporters offered little or no sympathy to men or women who died from alcoholism. And although newspaper reporters were far more likely to write articles about the deaths of men than women, they often used these deaths as an example of the dangers of alcohol. In contrast, reporters tended to write sympathetic or sensationalistic accounts of men and women who died by suicide, homicide, and accidents. St. Louis reporters had no sympathy for John A. Nicely and James Hardy, two native-born white men who died from alcoholism. Both men were hard drinkers, but lived and died in different ways. John Asberry Nicely was an unmarried, forty-six-year-old insurance claims adjuster and former steamboat captain. Nicely met his brother at a saloon on June 2,1880, but was already intoxicated when his brother arrived. Concerned, Nicely's brother and friends put him in a carriage to be taken to St. Vincent's Insane Asylum so that he would receive medical care and presumably treatment for his alcoholism. Nicely never received treatment, though, because he died shortly after his arrival at 9:00 that evening. Coroner Hugo Auler interviewed Nicely's brother and rendered a verdict that both described Nicely's cause of death and cleared St.

${ }^{71}$ Dr. E. Decaisne, "Dipsomania in Women," The Quarterly Journal of Inebriety 11 (1889): 247252; "Dipsomania and Heredity" in "Clinical Notes and Comments," The Quarterly Journal of Inebriety 10 (1888): 395-397; T.W. Fisher, M.D., "Insane Drunkards-Their Medico-Legal Relations," in "Clinical Notes and Comments," The Quarterly Journal of Inebriety 4, no. 1 (Jan. 1880): 18. 
Vincent's of any culpability: “Alcoholism. Died at the St. Vincent's Insane Asylum, upon his arrival there and before the attending physician called in."72

Although Auler's investigation and verdict do not reveal a stigma toward alcoholism in Nicely's death, the subsequent newspaper article does. The St. Louis reporter probably only wrote an account of Nicely's death because the coroner investigated another alcohol-induced death on the same day: that of James Hardy. In "The Coroner's Temperance Lecture," the St. Louis Globe-Democrat reporter recounted the details of the deaths of both Nicely and Hardy, but devoted a mere two sentences to Hardy's death. Hardy was a widowed steamboat cook who died behind an ice-box in a local saloon, where the barkeep found him at closing. Having no family nearby, the city buried Hardy in Potter's Field. Although the coroner conducted a longer inquest into Hardy's death than Nicely's because the circumstances surrounding his death were more mysterious, Hardy was not well-known and respectable in St. Louis, as was "Captain Nicely," accounting for the brief mention. ${ }^{73}$

The judgmental tone of these newspaper reporters reflects the fact that the mainstream St. Louis press did not find regular, heavy drinking to be respectable.

72 John Nicely Inquest, June 3, 1880, Case No. 2059, Folder 10, Box 22 (Missouri State Archives microfilm roll C31276), St. Louis City Office of the Coroner-Inquests 1845-1900, Missouri State Archives, Jefferson City, Missouri; “The Coroner's Temperance Lecture,” St. Louis Daily GlobeDemocrat, Friday Morning, June 4, 1880, 8; For two similar cases, both of white, working-class, unmarried men, see the following inquests: John Grady Inquest, July 6, 1885, Case No. 177, Folder 47, Box 43 (Missouri State Archives microfilm roll C31283), St. Louis City Office of the Coroner-Inquests 18451900, Missouri State Archives, Jefferson City, Missouri; Andrew Conlin Inquest, July 14, 1881, Case No. 250, Folder 51, Box 26 (Missouri State Archives microfilm roll C31278), St. Louis City Office of the Coroner-Inquests 1845-1900, Missouri State Archives, Jefferson City, Missouri. There is one onesentence mention of Grady's death in a St. Louis newspaper, but Conlin's death was not reported. See “Coroner's Cases,” St. Louis Daily Globe-Democrat Monday Morning, July 6, 1885, 10.

73 The Coroner's Temperance Lecture," St. Louis Daily Globe-Democrat, Friday Morning, June 4, 1880, 8; Hardy Inquest; Ancestry.com. Missouri, Death Records, 1834-1910 [database on-line]. Provo, UT, USA: Ancestry.com Operations, Inc., 2008. [accessed June 1, 2015]; St. Louis Genealogical Society, comp.. St. Louis City Death Records, 1850-1902 [database on-line]. Provo, UT, USA: Ancestry.com Operations Inc, 2001. 
Although St. Louis had over 2500 beer halls and saloons, its biggest newspapers and authors of a city guide distinguished between respectable, moderate drinking and the "worst scoundrels in America" who visited "dives" into the wee hours of the morning. The critical difference between social drinking and disreputable drinking was that respectable men and women did not become drunk and they were not "addicted" to visiting saloons. Although St. Louis had a thriving beer industry, social commentators carefully distinguished respectable and deviant drinking patterns. ${ }^{74}$

Men and women who died from accidents while intoxicated or illnesses made worse by alcoholism received no more sympathy than did those who drank themselves to death. The coroners in these cases added that alcohol contributed to the causes of death in each of these verdicts, which distinguishes them from verdicts of suicide, homicide, or accidental death. Some of these men and women had family members to testify before the coroner, but some did not. None of these men and women, however, had a good reputation, which explains why reporters and some witnesses did not sympathize with them. Their poor reputations also partially explains why no coroners determined that they were insane, along with the fact that no family members or friends testified that they suffered from insanity. Like the deaths in which alcohol was the direct cause of death, reporters were more likely to write accounts of the deaths of men than of women, but they seldom reported them at all.

74 Joseph A. Dacus, and James W. Buel, A Tour of St. Louis: or, The Inside Life of a Great City. St. Louis, Missouri: Western Publishing Co., 1878, 462-462, 478-481; The city also lacked a large temperance movement. In Her Place: a Guide to St. Louis Women's History (St. Louis: Missouri Historical Press, 1999), 106. Corbett notes that even though the WCTU held its national conference in St. Louis in 1882, the movement was not active in the city. Most WCTU members lived in small towns outside of the city or even the state. 
Coroners did not always note that individuals died while they were intoxicated, but Coroner John N. Frank added "while intoxicated" to his verdict of Joanna Hamilton's death from a concussion. The twenty-five-year-old suffered a head injury after she fell down the stairs while drunk late at night on April 27, 1882. Hamilton had recently separated from her husband because he learned that she was having at least one affair and had also been arrested for drunkenness several times. A police officer who knew Hamilton told the coroner that she worked as a prostitute as well, although it is unknown if his claims were true. At the time of her death, Hamilton was living with a friend and had just left an encounter with a man when she fell down the stairs while going to refill a pitcher of beer. ${ }^{75}$

Hamilton was not a respectable woman, regardless of whether she worked as a prostitute, because of her drunkenness and extramarital affairs. The coroner investigated her death until he learned its cause, but made sure to include her drunkenness in her verdict. Hamilton's case contrasts sharply with that of a woman who died by suicide while drunk: Catharina Lielich. Coroner Hugo Auler blamed Lielich's husband for her suicide in his lengthy verdict, but made no mention of her drinking all day. Unlike Hamilton, Lieich was a fifty-year-old wife and mother who was poor, a German immigrant, and a wife of an apparently abusive man. Hamilton, in contrast, was young Irish immigrant who was married to a man who had left her because she failed as a wife by drinking excessively and having affairs. Joseph Hamilton did not simply abandon his

75 Johanna Hamilton Inquest, April 29, 1882 Case No. 819, Folder 70, Box 29 (Missouri State Archives microfilm roll C31279), St. Louis City Office of the Coroner-Inquests 1845-1900, Missouri State Archives, Jefferson City, Missouri; An example of another St. Louis woman, "Mollie," or "Old Moll," known for her drinking and prostitution repeatedly served time in both the Work House and Jail can be found in this brief article: "Jokelets," St. Louis Post-Dispatch, July 11, 1895, 4. 
responsibilities as her protector and provider, he assured the coroner. He felt frustrated by his wife's choices. He concluded, "I blame nobody but herself for her death, which is caused by drink." St. Louis newspapers did not bother reporting her death, even though the details of her death may have made for a sensationalistic account. Because she was a presumed prostitute, her early death caused largely by drunkenness was likely unsurprising to local reporters. ${ }^{76}$

Alcohol also exacerbated illnesses, but in these cases, just as in other deaths caused by intoxication, the reputation of the deceased and testimony of their relatives about their heavy drinking contributed to their verdicts of alcoholism. Even when relatives told investigating coroners that their loved ones suffered from an addiction, however, their reputations often outweighed this testimony. Ellen Collins died about two weeks after she had married Charles Collins in January 1883 from pneumonia made worse by her heavy drinking. The twenty-eight-year-old's marriage would have been controversial because she was a native-born white woman who married an African American man. The fact that she was divorced before this interracial marriage certainly did not help her reputation. The St. Louis Globe-Democrat did not remark on her interracial marriage in its single sentence about her death, probably because they believed that she was "colored," an assumption they must have made when they interviewed her husband. The news account inaccurately reported that alcoholism alone caused Collins' death. Her husband made no mention of her drinking to the coroner, but only recounted her illness. Charles Collins likely wanted to spare his wife's reputation by omitting the

${ }^{76}$ Catherina Lielich Inquest, June 14, 1880, Case No. 2077, Folder 28, Box 22 (Missouri State Archives microfilm roll C31280), St. Louis City Office of the Coroner-Inquests 1845-1900, Missouri State Archives, Jefferson City, Missouri. See Chapter One for description of this death investigation; Hamilton Inquest. 
fact that she was drunk every day. Collins' sister, however, told Coroner S.L. Nidelet that her sister-in-law "was very much addicted to drink" and "craved it during her illness \& indulged freely." 77

Coroner Nidelet investigated more than most coroners in cases of alcohol-related deaths and sought a cause for her drinking — an abusive husband. Nidelet's concerns likely stemmed not from sympathy for a woman who suffered from alcoholism, but because of suspicion of Charles because he was a black man who married a white woman. Nidelet asked Ellen's sister-in-law if Charles abused or neglected Ellen, but she replied, "Her husband treated her well." White Americans had long perceived black men to be dangerous and coupling with a white woman not only raised fears of violence, but also challenged white supremacy. Coroner Nidelet, a former Confederate surgeon and son of a plantation owner, likely subscribed to these beliefs. Despite his investigation and apparent concern for Ellen Collins' well-being, Nidelet rendered a verdict of "pleuro pneumonia \& drink," perhaps not even considering that she suffered from dipsomania as he believed Ann Donahoe had. Despite the coroner's rejection of Collins as a woman who had a form of alcohol insanity, her sister-in-law believed that Ellen Collins was addicted to drinking. Almost no other witnesses referred to their friends, acquaintances, neighbors, or relatives as having an addiction, making Collins' case remarkable. Her testimony was not enough to convince the coroner of an addiction or insanity, however. ${ }^{78}$

${ }^{77}$ Ellen Collins Inquest, January 23, 1883, Case No. 1325, Folder 53, Box 32 (Missouri State Archives microfilm roll C31280), St. Louis City Office of the Coroner-Inquests 1845-1900, Missouri State Archives, Jefferson City, Missouri; “Local Brevities," St. Louis Daily Globe-Democrat, Tuesday Morning, January 23, 1883, 5.

${ }^{78}$ Collins Inquest; U.S. Census, 1850, 1860, 1870, 1880, 1910; Nidelet is listed as a Confederate in the following record: Civil War Prisoner of War Records, 1861-1865, ancestry.com [accessed July 1, 2011]; Prestwich, 329. For example, see: Maggie Tyler Inquest, May 18, 1883, Case No. 113, Folder 112, Box 33 (Missouri State Archives microfilm roll C31280), St. Louis City Office of the Coroner-Inquests 1845-1900, Missouri State Archives, Jefferson City, Missouri; Ellen Collins Inquest, January 23, 1883, 
Alcohol also contributed to heat stroke in several cases and despite being overwhelmed with inquests to conduct, coroners took the time and effort to distinguish between deaths caused by heat and those caused by heat as well as alcohol. There was a particularly extreme heat wave in July of 1881 that contributed to the deaths of three individuals in this chapter. The coroners' investigations into the deaths of men and women who died from heatstroke exacerbated by drinking vary markedly by gender. Coroners conducted more thorough investigations into the heat and alcohol-related deaths of men than they did women, in part because some were potential suicides. Press attention resembled these coroner's inquests: they reported the deaths of men more often than women. ${ }^{79}$

Deputy Coroner H. Praedicaw barely investigated the deaths of Ellen Maloney and Amanda McKinley on July 12, 1881, perhaps because their causes of death were clear, but also because they fit the stereotypes of chronic drinkers: an Irish woman and a prostitute, respectively. Praedicaw interviewed just one witness to determine the causes of death for Maloney, a thirty-five-year-old, Irish-born domestic servant, and McKinley, a twenty-six-year-old, native-born white married woman who worked as a prostitute. In both cases, he determined that the women died from "sunstroke and intemperance," also stated as "heat and liquor." Their drunkenness and poor reputations, combined with the heat wave, made it simple for Praedicaw to determine how they died. In both

Case No. 1325, Folder 53, Box 32 (Missouri State Archives microfilm roll C31280), St. Louis City Office of the Coroner-Inquests 1845-1900, Missouri State Archives, Jefferson City, Missouri.

${ }^{79}$ The St. Louis Post-Dispatch reported that on July 13, 1881, the morgue was so crowded that the bodies could not be contained in their two ice-boxes and even an additional private ice-box did not relieve the overcapacity of bodies. The article listed the names of all of the bodies in the morgue, but none of the individuals in this chapter are among them, although two died on July 12, indicating that they were buried quickly and/or not reported."Crowded Condition of City Morgue During the Hot Spell" in "Coroner's Cases," St. Louis Post-Dispatch, Wednesday, July 13, 1881, 4. Deaths caused only by heat are examined in Chapter Six, which examines natural deaths (those caused by disease/illness). 
McKinley's and Maloney's cases, the coroner left behind records with sparse details as to how these women came to their deaths. Newspapers did not report their deaths, not even when discussing the crowded morgue during the heat wave. The absence is notable because reporters listed almost every name of men and women who died during this period of excessive heat. ${ }^{80}$

In contrast to Maloney and McKinley, men who died from heatstroke and intoxication received more attention from investigating coroners and the press in part because two of their deaths were suspected suicides. Two of the men were also middleclass, which explains the greater attention paid to their deaths. J.C. Pinger died from alcohol and heatstroke in his rented hotel room on July 24, 1881, but investigators initially thought that the thirty-three-year-old widowed salesman poisoned himself, perhaps because he had just been fired for his heavy drinking. A friend who checked on Pinger found him "frothing at the mouth and his hands clutching convulsively," but the coroner found no suicide note, drugs, or chemicals in his room. Coroner John N. Frank was unsure of the cause of Pinger's death because he ordered Dr. C.V. Ludwig to conduct a postmortem examination, which included an autopsy. Pinger's lungs revealed his cause of death: "congestion of the lungs, superinduced by heat, and intemperance."

${ }^{80}$ Ellen Maloney Inquest, July 12, 1881, Case No. 241, Folder 42, Box 26 (Missouri State Archives microfilm roll C31278), St. Louis City Office of the Coroner-Inquests 1845-1900, Missouri State Archives, Jefferson City, Missouri; Amanda McKinley Inquest, July 12, 1881, Case No. 240, Folder 41, Box 26 (Missouri State Archives microfilm roll C31278), St. Louis City Office of the CoronerInquests 1845-1900, Missouri State Archives, Jefferson City, Missouri.

${ }^{81}$ J.C. Pinger Inquest, July 25, 1881, Case No. 94, Folder 243, Box 11 (Missouri State Archives microfilm roll C31278), St. Louis City Office of the Coroner-Inquests 1845-1900, Missouri State Archives, Jefferson City, Missouri. Reporters agreed with the coroner's initial belief. The initial account of his death reflects the assumption that he killed himself in its title: "Probable Suicide," St. Louis Daily Globe-Democrat, Monday Morning, July 25, 1881, 8. Pinger may have lost a previous job in Peoria, Illinois, for the same reason; One case was not initially suspected as a suicide and intemperance is not mentioned in the verdict, but is in the testimony. The deceased was probably middle class. See: Louis Luckel Inquest, July 21, 1885, Case No. 227, Folder 97, Box 43 (Missouri State Archives microfilm roll 
Particularly gruesome deaths in which alcohol played a role garnered more press attention than did other deaths caused by alcohol, especially if they were initially suspected to be suicides. The Globe-Democrat wrote a long account of the death of John Michael, who was run over by a train after lying on the tracks - twice-while he was drunk on July 10, 1877. Michael's death raises questions about whether someone who is drunk can intentionally take his or her own life. John Michael died on the train tracks after a night of heavy drinking with friends. Around midnight, a milkman saw him lying asleep on the railroad tracks. The milkman tried to load him onto his wagon, but Michael was too heavy. Instead, he dragged him to the side of the "railroad watchman's house." Michael evidently woke up and walked (or crawled) to the railroad tracks a second time, because it was there that a blacksmith found his remains around 5:00 a.m. He had been struck by the train and drug for about seventy-five feet which decapitated him and ripped some of his limbs and organs from his body. ${ }^{82}$

Whether a person can act with intent when intoxicated is, in general, a matter of debate and one that coroners did not discuss in their inquests. ${ }^{83}$ Perhaps his uncertainty is the reason why Auler did not conclude his verdict with the statement "accident" or "suicide." Instead, he rendered a long, ambiguous verdict, which was atypical for any

C31283), St. Louis City Office of the Coroner-Inquests 1845-1900, Missouri State Archives, Jefferson City, Missouri. Neither the Post-Dispatch nor the Globe-Democrat reported the death.

82 "Drink and Death," St. Louis Daily Globe-Democrat, Wednesday Morning, July 11, 1877, 8. Deaths caused by trains gained more attention from coroners than other causes of death during this time, largely because the coroner sought to determine if the train's engineer was in any way responsible for the deaths. The same is true of those who were run over by horses and buggies. See accident cases for examples. John Michael Inquest, July 11, 1877, Case No. 107-1, Folder 248, Box 11 (Missouri State Archives microfilm roll C31273), St. Louis City Office of the Coroner-Inquests 1845-1900, Missouri State Archives, Jefferson City, Missouri. The coroner interviewed six witnesses, but the testimony of only two of them remains in the record.

${ }^{83}$ Some physicians discuss intent, insanity, and alcoholism in medical journals, though. See, for instance: Surgeon-Major Robert Pringle, M.D., "Homicidal and Suicidal Inebriety," The Quarterly Journal of Inebriety 9 (1887): 156-164. 
coroner. Auler determined that Michael was "under the influence of Liquor before he was killed," and "he must have been either setting or lying down on the outside of the Railroad track at the time he was killed." Coroner Auler did not determine whether Michael's death was an accident or a suicide, but the fact that he may have returned to the tracks after being moved by the milkman suggests that he may have taken his own life. If someone lays across railroad tracks while he or she is sober, perhaps after threatening to commit suicide or even leaving a note, witnesses and coroners would almost certainly conclude that this person intended to take his or her own life. Sometimes coroners rendered verdicts of suicide with no mention of intoxication, while in other cases, they noted that the man or woman killed him or herself while drunk. The Globe-Democrat declared that it was "a frightful and fatal accident" but highlighted the role that alcohol played in the article and its title: "Drink and Death." Both the coroner and the newspaper reporter understood that alcohol contributed to John Michael's death, but at least the coroner was not exactly sure how alcohol helped cause Michael's death. ${ }^{84}$

In some cases, witnesses sought a root cause for the alcohol or drug use that led to the deaths of their loved ones, but even in cases of grief or other kinds of emotional distress, coroners did not believe that they were insane. The difference between the verdicts in deaths by suicide and those from alcoholism or alcohol use is striking. When men and women died by suicide whose relatives testified that they experienced melancholy, grief, or even obsessions, coroners subsequently rendered verdicts claiming that they died, in part, from "insanity" or "temporary insanity." Men and women who

${ }^{84}$ Michael inquest; "Drink and Death," St. Louis Daily Globe-Democrat, Wednesday Morning, July $11,1877,8$. 
died because of alcohol use differed not only because of their regular heavy drinking, but also because they had poor reputations, unlike the men and women who received qualified verdicts in their deaths by suicide.

Maggie Tyler's death is one example of the ways in which a poor reputation overshadowed potential evidence of insanity in cases of alcohol-related deaths. Tyler died from alcohol, laudanum, and opium use in a brothel on May 18, 1883. She was a native-born white, thirty-year-old widow, but resided in a brothel with primarily African American prostitutes during the last ten days of her death. When she arrived at Emma Baptiste's "house of ill fame" or "colored resort," she was in poor health. While each of the three witnesses told the coroner that "her death was undoubtedly due to her great dissipation," one of them, fellow prostitute Sarah Williams, sought a cause for her recent heavy use of opiates and alcohol. Williams, like the other witnesses, noticed that Tyler's use of liquor and drugs had increased shortly before her death, but she believed that this was because of her sister's recent death. After her sister died, she said, Tyler was "never sober." 85

Williams' testimony is more like that of witnesses in cases of suicide than in deaths from alcohol; she sought an event that triggered her friend's increased reliance on mind-altering substances. Ultimately, those substances killed her as she died suddenly on the afternoon of May 18, 1883, after refusing to go to a hospital. Coroner Nidelet determined that she died "from the effects of alcoholism," making no mention of either opium or laudanum. The brothel keeper took responsibility for burying her remains, as

${ }^{85}$ Maggie Tyler Inquest, May 18, 1883, Case No. 113, Folder 112, Box 33 (Missouri State Archives microfilm roll C31280), St. Louis City Office of the Coroner-Inquests 1845-1900, Missouri State Archives, Jefferson City, Missouri; “City News,” St. Louis Post-Dispatch Saturday, May 19, 1883, Supplement, 10 . 
Tyler apparently had no family in St. Louis. The St. Louis Post-Dispatch and Globe-

Democrat did not sympathize with Tyler at all and offered articles of a sentence or two recounting the bare facts of her death. The Post-Dispatch reporter called her an "unfortunate," perhaps referring to her death, occupation, or both. Widow or not, Tyler was a prostitute who freely associated with African Americans and used alcohol and drugs regularly. Like other disreputable women who died because of drunkenness, Tyler's death was not even seen by reporters to be worth a sensationalistic article warning others of the dangers of her "dissipated" and disreputable lifestyle. ${ }^{86}$

Coroners distinguished homicides in which alcohol contributed to a death from other homicides just as they did with accidents and illnesses. In one case, a coroner's jury even determined that a man died from a beating from other men because his brain had softened due to his excessive drinking. The jury called by Coroner Hugo Auler determined that forty-year-old Jacob Blumenthal, a rabbi and teacher who had immigrated from Poland, died from "blows on his head," but added that his "injuries [were] exacerbated by alcoholism." Late at night on November 23, 1877, Edgar Allen and Henry Smith attacked Blumenthal or got into a fight with him somehow, with their friend John Cooder nearby. Blumenthal later died from his injuries. Coroner Auler ordered an autopsy and Dr. Emil Sumaan concluded that Blumenthal died from a concussion combined with "chronic congestion of the brain" which "may have accelerated the hemorrhage of the brain.” After deliberating for a day and a half and

\footnotetext{
${ }^{86}$ Tyler Inquest; "City News," St. Louis Post-Dispatch Saturday, May 19, 1883, Supplement, 10; "Local Brevities," St. Louis Daily Globe-Democrat, Saturday morning, May 19, 1883, 8; The death of Julia Boyd is similar, but she was a black woman, not a white one. The testimony in her case is largely unreadable and the brief news piece does not shed light on her life and death, but like Tyler, she died from alcoholism and morphine. See Julia Boyd Inquest, February 19, 1880, Case No. 1872, Folder 103, Box 20 (Missouri State Archives microfilm roll C31276), St. Louis City Office of the Coroner-Inquests 18451900, Missouri State Archives, Jefferson City, Missouri.
} 
hearing the testimony of an astounding twenty witnesses, a coroner's jury of six men rendered a verdict that blamed "congestion of the brain" and "softening of the Cerebellum, caused by Alcoholism, and blows on his head," caused by Allen and Smith. Allen was convicted of manslaughter and served two years in prison, while Smith was eventually convicted of fourth-degree manslaughter. While Coroner Auler determined that Cooder was an accessory to the crime, he faced no charges. Only one local paper reported Blumenthal's death, The St. Louis Post-Dispatch, and referred to Blumenthal as a "peddler" who was found "in an insensible condition" just before his death—from intoxication or the beating, the reporter did not say. Although Blumenthal was beaten to death and his assailants arrested, neither the coroner's jury nor the press held them entirely responsible because of Blumenthal's drinking. They also claimed that he was a peddler when, in fact, he was a rabbi and teacher. ${ }^{87}$

Blumenthal's case is unique because he alone was not held accountable for his death, although a coroner's jury and physician agreed that his death did not occur only because of his head injuries. Blumenthal received a lengthy, thorough investigation and his attackers faced criminal indictments and jail time for killing him, but most of the men

${ }^{87}$ Jacob Blumenthal Inquest, November 25 and 26, 1877 Case No. 18, Folder 157, Box 12 (Missouri State Archives microfilm roll C31274), St. Louis City Office of the Coroner-Inquests 18451900, Missouri State Archives, Jefferson City, Missouri. The coroner called twenty witnesses in this death investigation, but the testimony is missing; St. Louis City Circuit Court, Criminal Court Record Book Volumes 19, 595-596; “The Cause of Blumenthal's Death,” St. Louis Post-Dispatch, November 26, 1877, 1.

In another case, a husband either accidentally or intentionally dropped an oil lamp on his wife while he was drunk, killing her. The coroner determined the death to be accidental, but some witnesses disagreed. Mary Morgan Inquest, January 23, 1879, Case No. 1201, Folder 75, Box 16 (Missouri State Archives microfilm roll C31274), St. Louis City Office of the Coroner-Inquests 1845-1900, Missouri State Archives, Jefferson City, Missouri; "Multiple News Items," St. Louis Globe-Democrat, Monday, January 20, 1879, 7; "Fruitless Researches," St. Louis Globe-Democrat, January 24, 1879, 7; “A Coal Oil Lamp," St. Louis Post-Dispatch, January 23, 1879, 4. 
and women most of the men and women who died from alcohol and/or drug use did not. Many received little or no sympathy from the press, investigating coroners, and even some of the witnesses who testified about their deaths. As with the other causes of death examined in this study the reputation of the deceased, testimony of relatives, and whether the coroner thought it was possible that someone else caused these deaths all shaped the death investigations and verdicts of men and women who died from alcohol use. Most of these men and women had bad reputations in their communities and, sometimes, among their relatives - if they were close to any relatives. Some had no close friends or relatives to explain why they drank so much that they died from alcoholism, an accident that occurred while they were drunk, or an illness made worse by drinking. But even in the cases in which relatives told coroners that their loved ones were "addicted" to drink, those coroners did not determine that they died from dipsomania or any other form of alcoholic insanity. Finally, newspaper reporters seldom printed sympathetic stories explaining these reasons, as they often did for people who died by suicide. Women and men who committed suicide by hanging, shooting, or drowning themselves gained sympathy and understanding, but those who died because of the bottle were often overlooked outside of their families and communities. 


\section{Chapter Three: "With the Intention of Producing an Abortion:" the Politics of Abortion}

Annie Roberts lay in bed suffering from "pains all over" on the night of

December 3, 1878, while her fiancé, Reuben Underwood, waited at her side. He had come to her room in a St. Louis boardinghouse perhaps still hoping that Annie, just twenty-five years old, would recover. But she no longer held out hope. Realizing the time remaining to them was short, she spoke her last words to Underwood, and then she died from the surgery she had wanted to keep hidden from him. ${ }^{88}$

Roberts had requested help from two physicians-Stephen Metcalf and William Stapp — but neither attended her that night as she grew increasingly ill. While both men had helped her earlier when she sought their care, they chose not to be present when she died. The reason was simple: they had helped her procure an illegal abortion. Roberts had asked Metcalf to perform the procedure days before her death, on November 26 and he referred her to Stapp, who frequently performed abortions. Roberts feared that her fiancé would leave her if he learned that she was pregnant with another man's child, prompting her to seek an abortion. While her reasons for having an abortion were unique to her life and circumstances, Roberts' decision was a common one in the late nineteenth century, particularly among married women who already had children. ${ }^{89}$

${ }^{88}$ Annie E. Roberts Inquest, December 6 and 7, 1878, Case No. 044, Folder 23, Box 13 (Missouri State Archives microfilm roll C31274), St. Louis City Office of the Coroner-Inquests 1845-1900, Missouri State Archives, Jefferson City, Missouri. Hereafter the case will be referred to as "Roberts Inquest." The testimony is missing from Roberts' inquest, but the St. Louis Globe-Democrat reprinted much of it verbatim. Newspapers often reported on the details of coroner's inquests and it was not uncommon for them to print the inquest testimony word-for-word, particularly in sensationalistic cases. "Sin and Death," St. Louis Globe-Democrat, Saturday, December 7, 1878, 2.

${ }^{89}$ Roberts Inquest; "Sin and Death," St. Louis Globe-Democrat, Saturday, December 7, 1878, 2; "At the Four C's," St. Louis Globe-Democrat, Tuesday, December 10, 1878, 8; "St. Louis in Splinters," St. Louis Globe-Democrat, Wednesday, January 15, 1879, 8; "An Unhappy Pair.," St. Louis Globe-Democrat, February 1, 1879, 3; "Four Courts Notes," St. Louis Globe-Democrat, Tuesday, July 15, 1879, 4; St. Louis City Circuit Court, Criminal Court Record Book Volume 20, 203, 205; Leslie J. Reagan, When Abortion 
A gap existed between abortion practice and policy in late nineteenth-century Missouri. Much earlier, in 1825, the state's lawmakers had criminalized the use of abortifacients. The law was supported, in fact advocated, by physicians concerned for the well-being of their patients. Missouri and other states subsequently expanded their laws to include more types of abortion, yet women continued to perform abortions upon themselves as well as to seek them from medical practitioners. Statutes intended to prevent malpractice targeted physicians and midwives who performed abortions, while treating the women who sought abortions as their victims. But the laws often went unenforced, and even in fatal cases such as Roberts's, criminal abortion was difficult to prosecute. Coroners, police officers, and prosecutors had to collect substantial evidence that a physician or midwife performed an abortion and that the abortion caused a woman's death. And although that evidence might clearly demonstrate that a practitioner was guilty of malpractice, it was still difficult to secure a conviction in a court of law. These circumstances surrounding the policies and legal processes regulating abortion both shaped and were shaped by the experiences and choices of women like Annie Roberts.

Although Missouri law in the 1870s made drug-induced, instrumental, and surgical abortions illegal at all stages of pregnancy, the general public, physicians, and law enforcement often tolerated the practice of abortion-except in cases of supposed malpractice. This was true not only in Missouri, but in most states. After all, most

was a Crime: Women, Medicine, and the Law in the United States, 1867-1973 (Berkeley: University of California Press, 1997): 21-23.

Portions of this chapter were published in The Missouri Historical Review. See: "The Untimely Death of Annie Roberts and the Politics of Abortion in Late-Nineteenth-Century St. Louis," The Missouri Historical Review 111. No. 3 (April 2017): 189-203. 
women remained healthy following abortions they had obtained or performed on themselves. Officials worked to prosecute physicians for abortions, however, if their patients were injured or died. Coroners investigated some of these deaths, leaving behind a record of a largely hidden practice that was nevertheless fairly commonplace. ${ }^{90}$

Physicians across the country joined the effort to criminalize abortion in the nineteenth century. Medical and legal experts held various views on why women sought abortions: some passionately argued that so-called evil women were to blame, while others advocated contraception or sex education to prevent unwanted pregnancies or, failing that, education about fetal development to dissuade women from seeking abortions. But they agreed on a few key points. First, criminal abortion was a social problem that must be solved. Second, despite stereotypes and sensationalistic stories about unmarried pregnant women, they believed, and used evidence to support their claim, that married women who already had children and did not want another accounted

90 James C. Mohr, Abortion in America: The Origins and Evolution of National Policy, 1800-1900 (New York: Oxford University Press, 1978), 230-233. The term “abortion" is used in this essay as Mohr and Leslie J. Reagan define it: "the purposeful ending of pregnancy at every stage." See Reagan, When Abortion Was a Crime, 24; she draws on Mohr's definition of abortion as "the intentional termination of gestation by any means and at any time during pregnancy from conception to full term" (Mohr, Abortion in America, viii). Reagan and Mohr's works are foundational for the historical study of abortion. Other key works about abortion policy, practice, rhetoric, and debates include: Kristin Luker, Abortion and the Politics of Motherhood (Berkeley: University of California Press, 1984); Rosalind Pollack Petchesky, Abortion and Woman's Choice: The State, Sexuality, and Reproductive Freedom (New York: Longman, 1984); Janet Farrell Brodie, Contraception and Abortion in Nineteenth-Century America (Ithaca, NY: Cornell University Press, 1994); Rickie Solinger, Pregnancy and Power: A Short History of Reproductive Politics in America (New York: New York University Press, 2005); Sara Dubow, Ourselves Unborn: A History of the Fetus in Modern America (New York: Oxford University Press, 2011); Nathan Stormer, Articulating Life's Memory: US Medical Rhetoric about Abortion in the Nineteenth Century (Lanham, MD: Lexington, Books, 2002); Stormer, Sign of Pathology: US Medical Rhetoric on Abortion, 1800s-1960s (University Park: Pennsylvania State University Press, 2015). Although many anti-abortion physicians claimed that abortionists specialized in the practice, many abortion providers were in fact practicing obstetricians and gynecologists who performed abortions along with other services. Reagan, When Abortion Was a Crime, 54. 
for the vast majority of abortions. In addition, most of the experts believed that abortions had become more prevalent in the late nineteenth century. ${ }^{91}$

As the historian James C. Mohr argues, physicians lobbied for state laws against abortion for a variety of reasons. Many of them wanted to protect women from dangerous procedures, but they also sought to avoid losing patients to other doctors who were willing to perform abortions. They worked to create a professional niche for themselves as obstetricians and gynecologists and to eliminate competition from so-called irregular physicians and midwives, particularly after the formation of the American Medical Association in 1847. As physicians began to create professional standards and organizations, they turned to the law to regulate each other. New research about pregnancy created a general belief among many physicians that life began at conception and the law should protect fetal life at all stages. These doctors dismissed the traditional “quickening doctrine," which held that abortion was moral as long as it was before "quickening" - the moment when a mother could feel the fetus move, around the fourth month of a pregnancy. In this way, the beliefs of many physicians overshadowed the experiences of women that had been respected for centuries. ${ }^{92}$

But the concerns of physicians who opposed abortion were not simply driven by professional motives and moral concerns. Some also worried about "race suicide" - that the birth rate was declining among married middle- and upper-class white, Protestant

${ }^{91}$ J. Berger, “A Fatal Fashion,” St. Louis Medical Journal 12, no. 7 (July 1885): 289-96; Mary A. Dixon-Jones, "Criminal Abortion: Its Evil and Sad Consequences," Medical Record 46 (July 7, 1894): 916; William B. Ely, "The Ethics of Criminal Abortion," Western Medical Review 10, no. 3 (March 1905): 97-102; Everett W. Burdett, "The Medical Jurisprudence of Criminal Abortion," New England Medical Gazette 18 (July 1883): 200-214; Raymond M. Spivy, "The Control and Treatment of Criminal Abortion," Journal of the Missouri State Medical Association 15, no. 1 (January 1918): 1-5; C. S. Bacon, "The Duty of the Medical Profession in Relation to Criminal Abortion," Illinois Medical Journal 7 (1905): 18-24.

${ }_{92}$ Mohr, Abortion in America, 21, 22, 25; Reagan, When Abortion Was a Crime, 8. 
women while it increased among African American and immigrant women, particularly Catholics. Many also feared the destabilization of gender conventions and believed that abortion made it possible for women to avoid motherhood. ${ }^{93}$

As the historian Leslie Reagan observes, however, while many physicians advocated for laws against abortion and joined the American Medical Association and other organizations that supported these efforts, doctors also were performing abortions in response to women's needs, their own consciences, and their fear of losing paying patients. In addition, physicians could legally perform therapeutic abortions - those to save the life of the mother-an exception added to Missouri abortion laws in the 1840s. Physicians had the sole discretion as to what constituted a therapeutic abortion. ${ }^{94}$ Yet when it came to malpractice, St. Louis coroners and district attorneys did not tolerate any motives for performing abortions, but sought to convict abortionists of violating Missouri law.

Missouri was a national leader in creating and strengthening laws against abortion. The 1825 law made it the second state to criminalize abortion, following Connecticut. This initial Missouri law targeted poisonous abortifacients because they harmed and even killed women. Lawmakers revised the statute in 1835, adding the criminalization of abortions performed with surgical instruments, but only after quickening. A decade later, lawmakers specified that physicians, midwives, or anyone else who performed an abortion was committing a crime, whether they used drugs or an

93 "Race Suicide (Criminal Abortion)," in "Correspondence," Journal of the American Medical Association 46, no. 13 (March 31, 1906): 972. Although women physicians were a rarity in the nineteenth century, at least one subscribed to the theory of her male counterparts that abortions undermined gender conventions for women. See Dixon-Jones, "Criminal Abortion: Its Evil and Sad Consequences."

${ }^{94}$ Reagan, When Abortion Was a Crime, 4-5. 
instrument. But legislators also relaxed the law by adding that physicians could perform therapeutic abortions to save a woman's life. Later revisions to the statute altered the prescribed punishments, making them harsher if a doctor or midwife performed an abortion after quickening. The Missouri statutes in 1872, 1879, and 1889 all declared that if an abortion provider harmed a woman after quickening, he or she would be charged with first-degree manslaughter; only misdemeanor charges were brought for harm caused by an abortion performed before quickening. The physician or midwife could face murder charges if the mother died as a result of the procedure, however. While these later laws established more specific punishments, their substance changed little. Missouri abortion laws always targeted physicians and midwives, not the women who sought abortions. $^{95}$

Although lawmakers sought to prevent such deaths, it was uncommon for women to die from abortions. Coroners in St. Louis investigated far fewer abortions than suicides, accidents, homicides, or other causes of death. In fact, of the tens of thousands of inquests into the deaths of men and women in St. Louis conducted by coroners

\footnotetext{
${ }^{95}$ Mohr, Abortion in America, 25; Laws of the State of Missouri (St. Louis: E. Charless, 1825), 283; Revised Statutes of the State of Missouri (St. Louis: Argus Office, 1835), 168; Revised Statutes of the State of Missouri (St. Louis: J. W. Dougherty, 1845), 351. The law specified such a punishment for either a drug- or instrument-induced abortion. Statutes of the State of Missouri, 3rd ed. (St. Louis: W.J. Gilbert, 1872), 1:445-47; General Statutes of the State of Missouri (Jefferson City: Emory S. Foster, 1866), 781; Revised Statutes of the State of Missouri (Jefferson City: Carter and Regan, 1879), 1:219-20; Revised Statutes of the State of Missouri (Jefferson City: Tribune Printing Co., 1889), 1:849-50. As was noted by physicians, Missouri continued to have some of the strongest laws in the nation in the early twentieth century. See "Criminal Abortion in Its Broadest Sense," Journal of the American Medical Association 51, no. 12 (September 19, 1908): 957-61. The house and senate journals for Missouri do not mention discussion of abortion statutes or their sponsors, and newspapers rarely discuss the sponsors of these laws. However, between 1822 and 1889 these records feature discussions of regulations regarding physicians at the Missouri State Penitentiary and Insane Asylum. See, for example, Journal of the Missouri House, Fourteenth General Assembly, First Session, 1846, p. 416, General Assembly, Record Group 550, Missouri State Archives, Jefferson City; Laws of Missouri, General Assembly Twenty-Eight, Regular Session, 1875 , p. 99, State Documents Collections, Missouri State Archives, Jefferson City; Missouri Session Laws, 1824-present.
} 
between 1845 and 1900, only 180 verdicts mention "abortion" in the cause of death.

Because abortion was a medical term, these numbers include "spontaneous" or

"accidental" abortions, which would today be called miscarriages. The verdicts are

inconsistent; some list the cause of death as "homicide, self-induced abortion" or

"criminal abortion," while others simply say "abortion." Because there are few records

for the illegal procedure, it is impossible to determine how many women terminated their

pregnancies or died as a result, but historians estimate that abortion was about as safe as

childbirth. Women were also more likely to die from self-induced abortions than from

those performed by a physician or midwife. ${ }^{96}$

The women in this chapter shared more in common than dying from abortions or,

in one case, a possible miscarriage: all were poor or working class, which made abortions

dangerous for them because it was difficult to access safe, professional medical care.

Poor and working-class women were also less likely than their middle and upper-class

counterparts to have family physicians to create false death certificates to avoid coroners'

inquests into their deaths, as was not uncommon in deaths from abortions. ${ }^{97}$ Besides their

class positions, these women also shared similar family dynamics. Every woman was

${ }^{96}$ Of these 180 inquests, coroners only investigated the deaths of 40 women; the other 140 were conducted on fetuses and infants, some of whose identities were unknown. The data was found by searching for "abortion" as the cause of death in the Coroner's Inquest Database. St. Louis City Office of the Coroner, Inquests, 1845 to 1900, accessed August 5, 2016,

https://s1.sos.mo.gov/records/archives/archivesdb/coroners/Results.aspx. Physicians in the nineteenth century, including coroners, referred to some miscarriages as abortions, particularly those that occurred later in pregnancies. Women did not use the term "abortion"; it was a medical term. Reagan, When Abortion Was a Crime, 8, 24. For an example of a miscarriage with a verdict of "accidental abortion," see Ellen Noonan Inquest, August 30, 1882, case no. 1046, folder 147, box 30 (Missouri State Archives microfilm roll C31279), St. Louis City Office of the Coroner-Inquests 1845-1900, Missouri State Archives, Jefferson City; Mohr, Abortion in America, 18-19; Reagan, When Abortion Was a Crime, 77.

97 The treating physician did just that in the case of Annie Roberts, as will be discussed later, but someone altered the coroner before she could be buried. For another example of a false death certificate created by Dr. Stapp, see: Many Such.: Sad Case of Abortion and Morphine Poisoning," St. Louis PostDispatch, September 5, $1882,7$. 
already a mother when she became pregnant for the last time, yet they were all also either separated from their husbands or unmarried. They were not adding to happy families with these pregnancies, which is why at least three were unwanted. One drank heavily, while another was married to a man who probably would have been considered to be an alcoholic. Two worked as prostitutes or at least in brothels-fitting the stereotype of the fallen woman who would seek an abortion, yet the press did not write sensationalistic accounts demonizing these women, instead writing brief, and even somewhat sympathetic accounts. Like women who died from alcoholism or suicide, the press often treated them as victims of "bad" men, particularly Annie Roberts, who died after a physician performed an abortion at her request. ${ }^{98}$

Ellen "Nettie" Noonan died suddenly from a miscarriage in 1882 and it is unknown whether or not she terminated her pregnancy, but it is possible that the criminal abortion law delayed her access to health care and resulted in her death. Because of antiabortion laws, the investigating coroner, John N. Frank, could have investigated her miscarriage to ensure that it was not caused by an abortion, but he did not. In part, Frank likely made his decision because there was no evidence that a doctor or midwife aided Noonan in terminating the pregnancy, but the coroner also because believed that she miscarried. Twenty-five-year-old Noonan was between six and seven months pregnant when she came to the City Hospital on the morning of August 27, 1882, stating that "she was about to miscarry," which she then did. Why she waited until the last moment to come to the hospital or what caused her miscarriage, the treating physician did not know.

${ }^{98}$ Leslie J. Reagan, When Abortion was a Crime: Women, Medicine, and the Law in the United States, 1867-1973 (Berkeley: University of California Press, 1997), 40-41, 73.

Three women in this chapter were native-born white women, while one was born in Ireland, only one was middle-class, and they ranged in age from 25 to 30. 
She suffered from pain, a high fever, heavy bleeding, and anemia, which caused her death that evening from septicemia "following an accidental abortion" or "accidental miscarriage," on the evening of August 27, 1882. ${ }^{99}$

Noonan may have concealed her pregnancy and miscarriage because her estranged husband was almost certainly not the father of her unborn baby. When she moved to a residence on Eighth Street four months earlier, she told her neighbor Clara Mason that she was widowed, but, in fact, her husband was alive, well, and working in St. Louis. Mason had no idea that Noonan was pregnant until she asked for help because she was losing the unborn baby. Noonan had been separated from her husband for two years, although they had never divorced, perhaps because she was Catholic. Noonan even asked the hospital to notify her sister-in-law, not her husband, of her death. ${ }^{100}$

Noonan had other secrets as well, but the press still sympathized with her, probably because she was a mother who had lost an infant the year before. Mothers who had lost young children often gained the sympathy of the press. Noonan had a rough history; she was often drunk and spent time in the Work House for prostitution shortly before her miscarriage. She struggled to support herself in any way possible. She worked as a laborer in a local foundry, but probably worked as a prostitute at least on occasion to support herself, as the newspapers referred to her "life of shame," but with a bit of sympathy. Noonan also had another child, whom someone must have cared for while she served time in the Work House. When she died, her brother could not afford to bury her and the city placed her remains in Potter's Field. Whether she avoided help

${ }^{99}$ Ellen Noonan Inquest, August 30, 1882, Case No. 1046, Folder 147, Box 30 (Missouri State Archives microfilm roll C31279), St. Louis City Office of the Coroner-Inquests 1845-1900, Missouri State Archives, Jefferson City, Missouri.

${ }^{100}$ Noonan Inquest. 
until the last minute because she had performed or received an abortion, simply wanted to avoid a possible investigation into her miscarriage, or for other reasons is unknown. What is known is that she concealed her pregnancy while trying to start a new life away from her estranged husband and was a poor woman with a questionable reputation at best. But Coroner Frank investigated her death as a miscarriage, not an abortion, and she also gained some sympathy from the local press. ${ }^{101}$

The death of Mary Baum is similar to that of Ellen Noonan in that she was also an unmarried mother with a questionable reputation, but her death was clearly caused by a self-inflicted abortion, unlike Noonan's. Still, the coroner did not file any criminal charges in her death, even though others knew about her abortion. Baum moved in to Mrs. Saurens' brothel one week before her death in November of 1881, but whether she worked as a prostitute or a cook is not clear. A fellow resident, Katie Rupert, said that she suspected that Baum was "in the family way" because she experienced a lot of pain and could keep little food down in the days before her death, but Baum never said anything about her pregnancy. Rupert, Baum's acquaintance of one week, was the closest person to her and told Coroner John N. Frank that the twenty-seven-year old had been widowed for eight months. She moved to St. Louis from St. Charles, but had left her two young children with adoptive families in St. Charles. No one speculated as to whom the father of Baum's unborn child might be, but it was clearly not her husband and could have been a lover or a client. Her pregnancy would have prevented her from

${ }^{101}$ Noonan Inquest; "The Noonan Inquest.," St. Louis Globe-Democrat, St. Louis, Missouri, Tuesday, August 29, 1882, 10; “A Very Distressing Case.,” St. Louis Globe-Democrat, August 31, 1882, 12; Death Record for Infant of Ellen Noonan, St. Louis Genealogical Society, comp.. St. Louis City Death Records, 1850-1902 [database on-line]. Provo, UT, USA: Ancestry.com Operations Inc, 2001 [accessed January 20, 2016]. 
working (much less participating in respectable society unless she fabricated a history for herself) and she performed a "violent abortion" on herself at some point. She soon developed a severe infection and rested in bed. The day before Baum died, Mrs. Saurens requested a physician to treat Baum, but told the other women that "small pox was coming on," revealing nothing about Baum's pregnancy or abortion. The doctors were not able to help Baum, however, and she died from peritonitis, or an abdominal infection, the evening of November 2, 1880. The other residents of the brothel then notified the coroner of her death. ${ }^{102}$

Although Mrs. Saurens initially concealed the abortion from the other brothel residents, she evidently did not fear any legal repercussions after Baum died. Or she may have worried that the treating physician would notify the coroner that Baum had died from complications from an abortion. The fact that the brothel keeper tried to hide Baum's illness after her abortion could have raised the suspicions of the coroner, but he had no evidence that anyone had assisted Baum with the procedure and, thus, no reason to implicate anyone else. No one faced criminal charges. Sadly, no one claimed Baum's remains, either, and the city buried her in Potter's Field. ${ }^{103}$

Baum's death is just one example that shows that abortions were not sensationalistic stories like suicides and homicides unless physicians performed them. Even though Baum's death could have been a sensational story, the St. Louis press barely mentioned it. Baum worked as a prostitute and the brothel owner had tried to conceal her

\footnotetext{
102 Mary Baum Inquest, November 3, 1881, Case No. 516, Folder 117, Box 27 (Missouri State Archives microfilm roll C31278), St. Louis City Office of the Coroner-Inquests 1845-1900, Missouri State Archives, Jefferson City, Missouri; "Locals in Brief," St. Louis Globe-Democrat, Thursday, November 3, 1881, 6. Her husband was evidently killed in his work as a railroad employee, perhaps in St. Charles

${ }^{103}$ Baum Inquest.
} 
abortion, at least at first, both of which could have been evidence that stereotypes about abortion were true. But the St. Louis Globe-Democrat mentioned her passing only in a sentence, noting that she lived in a "house of ill-fame."104

Although the brothel keeper reported Baum's abortion after initially concealing it from the other residents, in some cases, physicians, midwives, or others tried to hide abortions from investigating coroners to prevent being implicated in the procedures. Mrs. A.S. Miller, a midwife, tried to hide her involvement in the abortion of Mrs. Kate McClure, who died on July 24, 1881. Coroners almost never recorded the prefix "Mrs." Or "Mr." in front of the deceased's name and often did so only for men and women who were prominent, indicating that thirty-year-old McClure was a respectable woman. Her good reputation sets her apart from the other women in this chapter, but otherwise, the investigation into her death is quite similar. Unlike the other women in this study, McClure's husband was likely the father of her child, but her marriage was far from happy. McClure moved to the boardinghouse of Mrs. A.S. Miller, a midwife, with her two young children either several weeks before her death. Shortly after renting a furnished room, she received a letter about her husband, who worked as a butcher in Cincinnati. The letter upset McClure because it revealed that her husband had been drinking excessively recently and even risked dying. McClure then decided to terminate her pregnancy, but something went wrong and she died from complications from the procedure. Miller, the midwife and boardinghouse owner, insisted to Coroner John Frank that she did not help McClure obtain an abortion. ${ }^{105}$

104 "Locals in Brief," St. Louis Globe-Democrat, Thursday, November 3, 1881, 6.

${ }^{105}$ Mrs. Kate McClure Inquest, July 24, 1881, Case No. 277, Folder 78, Box 26 (Missouri State Archives microfilm roll C31278), St. Louis City Office of the Coroner-Inquests 1845-1900, Missouri 
Whether Miller did assist McClure is not known, but the coroner did not investigate Miller or the physicians who treated her, indicating that he either believed her or did not have enough evidence to investigate her. As a midwife who ran a boardinghouse, Miller could have been operating what historian James Mohr calls a "cooperative boardinghouse," in which the boardinghouse keeper provided pregnant women with a play to stay before and after they had abortions and even helped them acquire these abortions. ${ }^{106}$ But Coroner Frank had no concrete evidence that Miller assisted McClure with the abortion. Frank probably also believed the midwife because McClure had, in fact, performed four other abortions upon herself. She also already had two children. When she terminated the other four pregnancies is unknown, but she could very well have done so after having these two children to limit her family size, as was fairly common practice. ${ }^{107}$

Miller's testimony reveals that both midwives and physicians feared facing criminal charges from assisting with or performing abortions, evidenced by the difficulty in obtaining medical treatment to help McClure after her abortion. Miller told the coroner that she had done everything possible to save McClure and had no knowledge of her abortion until after she had already begun to miscarry. On the afternoon of her death, McClure asked for Miller's help when she realized that she was experiencing a miscarriage. Although the midwife testified that she asked McClure to send for a doctor, McClure refused. Miller told Coroner Frank that she ignored McClure's request and tried

State Archives, Jefferson City, Missouri. The words are hard to read here, but it is clear that he was drinking excessively and the word "deceased" is readable.

${ }^{106}$ Some of these boardinghouses were evidently nothing more than places where women could wait to have an abortion and recover after, with the boardinghouse keeper even referring women to physicians. Stemp's house does not seem to have had this sole purpose, but she did cooperate with Stapp and Metcalf on at least some occasions. Mohr, 96-97.

${ }^{107}$ Reagan, When Abortion was a Crime, 40. 
to call Dr. D.W. McCarthy, but he refused to treat her because she had had an abortion. Miller then apparently called Dr. Fischel, who came twice, but then refused because he claimed to be ill. In all likelihood, Fischel realized that McClure was beyond help and sought to avoid possible criminal charges from being implicated in her deadly abortion. Finally, Dr. Younkin came, but he could not save McClure from dying from metroperitonitis, meaning an inflammation of her uterus, caused by the abortion. She died in the early morning hours of July 22, 1881. Her brother-in-law, Mr. King, took charge of her remains and notified her husband. Her remains rest in the Catholic Calvary Cemetery in St. Louis. ${ }^{108}$

Because McClure was a respectable married woman and had performed an abortion upon herself, the St. Louis press did not write a sensationalistic account of her death. Instead, a local reporter showed respect for her by running a brief piece about her death, buried in the page. The reporter said that McClure died from "individual malpractice" from an "operation" that she had performed on herself four times beforecoded language to discuss abortion. ${ }^{109}$

Although McClure attempted to receive medical care from three physicians and also had the aid of a midwife, Coroner Frank did not investigate any of them, much less bring charges against them, probably because he had no evidence to do so. McClure was a married woman and one who had performed several abortions on herself before, evidently safely. She also had a husband who was an apparent alcoholic, which likely

\footnotetext{
${ }^{108}$ Whether or not King was a prominent St. Louisan is not yet known, but if so, it could explain why McClure was treated with more respect than other men and women; Amcestry.com, St. Louis, Missouri, Burial Index, Archdiocese of St. Louis, 1700-2010 [database on-line]. Provo, UT, USA: Ancestry.com Operations, Inc., 2011 [accessed January 20, 2016]; Ancestry.com, Missouri, Death Records, 1834-1910 [database on-line]. Provo, UT, USA: Ancestry.com Operations, Inc., 2008 [accessed January $20,2016]$.

109 “'Splinters,” St. Louis Globe-Democrat, Saturday, July 30, 1881, 3.
} 
garnered her some sympathy. Yet the physicians whom the boardinghouse keeper and midwife called were all reluctant to aid McClure, indicating that they feared that they would be investigated and possibly face criminal charges for malpractice.

These physicians' concern was justified, as the investigation into the death of Annie Roberts, discussed in the opening story, illustrates. Perhaps the odds for a safe outcome gave Annie Roberts confidence when she sought an abortion from Metcalf and Stapp. An unwanted pregnancy had interrupted the new life that Roberts had created for herself in St. Louis. She had come to the city two years earlier, in 1876, with her oneyear-old daughter, claiming to most people whom she met to be married to a husband who "was compelled to be away." But Roberts's story was a lie to protect her reputation, she confided to Carrie Stemp, the owner of the boardinghouse at 3310 North Eleventh Street in which she rented a room. Roberts revealed to Stemp that she was an unwed mother, having been “seduced” by Michael O'Brien, a man from her hometown of Little Rock, Arkansas. In moving to St. Louis, Roberts had not left O’Brien behind. In fact, he visited her at least once. Stemp later told the coroner that O'Brien "kept 'shady" when he visited, suggesting that he did not act as a respectable man should. O'Brien apparently expected to continue his relationship with Roberts and even gave her money to move to a new residence, ostensibly so that they could avoid the disapproval of the boardinghouse keeper and the other residents. Roberts, however, had different plans. O'Brien was not the only man in her life; she was engaged to Reuben Underwood. Roberts did not tell Underwood about O'Brien. It is unknown what Roberts told Underwood about the father of her daughter, but she may have told him that she was widowed. Roberts underwent an abortion to conceal her pregnancy from Underwood, she told Stemp, because she was 
afraid that he would lose his "high opinion of her." If he broke off their engagement, her options would be limited, as her tarnished reputation would make it difficult to find work or to marry. ${ }^{110}$

Roberts had been about four months pregnant when she went to Dr. Metcalf's downtown St. Louis office, two weeks before her death. Metcalf prescribed iron pills to induce a miscarriage, but they failed to work. ${ }^{111}$ Roberts then asked the physician to perform a surgical abortion. Metcalf claimed that he did not have the necessary surgical instruments and referred her to Dr. Stapp, an obstetrician and gynecologist who performed abortions. Roberts went to Stapp's office on the afternoon of November 27 and then returned to the boardinghouse, telling Stemp and a fellow resident and casual friend, Carrie Vanderbrugge, that she "expected to be ill that evening," meaning she would soon lose the fetus because she had had an abortion. Abortions were not immediate; physicians or women used instruments or drugs to cause a miscarriage, which could take several hours. ${ }^{112}$

Roberts expected to recover quickly from the abortion, but the outcome of the surgery did not go as planned. The next morning Stemp asked another resident of the boardinghouse to get Metcalf to help Roberts. She did not reveal the reason for Roberts's

${ }^{110}$ Roberts Inquest; "Sin and Death."

${ }^{111}$ Mohr points out that physicians often performed surgical abortions at no extra charge if the medications they prescribed to induce abortions failed. Mohr, Abortion in America, 97. Metcalf may have prescribed iron pills to build up blood in the uterus as a way to "unblock" menses. Many women sought treatment for "blocked" menses as opposed to an abortion.

112 "Sin and Death"; Directory of Physicians, Dentists and Druggists of Missouri, 1889 (St. Louis: G. Gonser \& Co., 1889), 105; Reagan gives several examples of this throughout her book. See also Roberts Inquest; Mary Baum Inquest, November 3, 1881, case no. 516, folder 117, box 27 (Missouri State Archives microfilm roll C31278), St. Louis City Office of the Coroner-Inquests 1845-1900, Missouri State Archives, Jefferson City; Mrs. Kate McClure Inquest, July 24, 1881, case no. 277, folder 78, box 26 (Missouri State Archives microfilm roll C31278), St. Louis City Office of the Coroner-Inquests 18451900, Missouri State Archives, Jefferson City. 
sickness. Metcalf came at Stemp's request and delivered Roberts's fetus at 2 a.m.

Although Roberts at first appeared to be recovering after Metcalf left, her health soon declined. Stemp sent for the physician again a few days later, but this time he refused to come, claiming that he was sick. Dr. Fischel had also claimed to be sick when McClure needed treatment, indicating that pleading an illness was a tactic that physicians sometimes used to avoid being implicated in women's deaths from abortions. While Metcalf would not treat Roberts, Stapp did. He looked in on her on December 3-almost a week after her abortion. Roberts's health was growing worse, and she suffered from intense pain. ${ }^{113}$

Certain that she was going to die, Annie Roberts then made a startling confession: neither Reuben Underwood, her fiancé, nor Michael O'Brien, the father of her now threeyear-old daughter, was the father of her unborn child. She told Stemp and Underwood that the father was a St. Louis police officer, J. W. O’Neill. Entangled in a messy love triangle, she had hoped that terminating her pregnancy would resolve at least part of her predicament by preserving her engagement. Having confessed, Roberts passed away at about ten o'clock that night from peritonitis, the result of a puncture wound to her uterus. Underwood never left her side; he later paid for her burial. ${ }^{114}$

Stemp and Stapp tried to conceal Roberts's death, but without success. Stapp created a false death certificate while Vanderbrugge and Stemp prepared the body for a quick burial, but a neighbor notified the coroner that they suspected foul play. Coroner Hugo Auler, MD, investigated Roberts's death as a potential homicide because she had

\footnotetext{
113 Roberts Inquest; "Sin and Death."

114 Ibid.
} 
died from an abortion performed by one physician and aided by another. As was typical in suspected homicides, Auler interviewed witnesses before a coroner's jury of six men. If the jury rendered a verdict of homicide, then they would also decide if Metcalf or Stapp should be charged with murder or manslaughter. Although it was possible that the coroner's jury could also hold Roberts or anyone else accountable for her death from abortion, it was highly unlikely. Missouri statutes indicated that physicians and "any other persons" would be guilty of manslaughter if they aided an abortion, or of murder if the mother died from the abortion, but "other person[s]" was understood to refer to midwives and druggists, not the patients themselves. ${ }^{115}$

Not only did Coroner Auler and his jury seek to determine how and why Roberts died, but they also sought to ascertain if Drs. Metcalf and Stapp should face criminal charges. The testimony of the boardinghouse keeper, Mrs. Stemp, and residents implicated both physicians in assisting with Roberts' abortion. Stemp told the coroner and his jury that she tried to dissuade Roberts from having the procedure because it could kill her. Stemp said that Roberts ignored her warning, though, and even said that "“she didn't care"” if she died because "she didn't want Mr. Underwood [her fiancé] to find out her condition, as he had a high opinion of her character." Stemp probably told the coroner's jury that she tried to prevent Roberts from having an abortion because she

115 Statutes of the State of Missouri (1872), 3:445-50; Revised Statutes of the State of Missouri (1879), 1:219-20; Revised Statutes of the State of Missouri (1889) 1:849-50. Even into the early twentieth century, women seldom faced convictions for abortion. The Missouri State Penitentiary Records show only one woman, Frances Spinner, an African American, who served a sentence for abortion (presumably for performing one upon herself, but perhaps on another woman). A judge commuted Spinner's three-year sentence because she was ill. Frances Spinner, page 228, Volume DD, Reel S230, Missouri State Penitentiary Database, Missouri State Archives, Jefferson City, Missouri. http://s1.sos.mo.gov/records/archives/archivesdb/msp/Detail.aspx?id=35156 [accessed December 20, 2016]. 
could have been charged with a crime as an accessory. Stemp helped Roberts recover from her abortion, acquire medical care for unexpected complications, and tried to conceal it when she died. Stemp tried to hide Roberts' abortion from other boardinghouse residents, except for one, Carrie Vanderbrugge, because she already knew about it. There is also no evidence that she helped Roberts procure an abortion. Stemp's testimony revealed that she knew about the procedure, however, and tried to avoid possible criminal charges for her involvement in it. ${ }^{116}$

While Mrs. Stemp told Coroner Auler and his jury that both Drs. Metcalf and Stapp treated Annie Roberts, when the two physicians took the stand, they denied having anything to do with her abortion. Dr. Metcalf claimed that he had seen Roberts two months before her death, but she was not pregnant, nor was there evidence that she had “'been intimate' with anyone." He prescribed her something at that time (probably iron pills to cause an abortion, based on other testimony), but he did not see her again until he was called to the boardinghouse, where he discovered that she was in labor. He gave her morphine to ease her pain, but told her to get the help of another physician. He treated her once more and delivered a deceased fetus and he then determined that she had had an abortion, he told the jury. In addition to trying to prove that Dr. Metcalf had assisted with the abortion, Coroner Auler also sought to determine his medical expertise—or lack thereof. Dr. Metcalf admitted before the coroner's jury that he had no medical degree, "but had attended lectures." Dr. Metcalf insisted that he had nothing to do with her acquiring an abortion, nor did he refer her to Dr. Stapp. He also claimed that he did not know that Dr. Stapp was a "noted abortionist," but considering that Dr. Stapp regularly

116 “Sin and Death;” Roberts Inquest. 
performed abortions, Dr. Metcalf was probably lying. He said that he told the women in the boardinghouse who knew about the abortion not to talk about procedure only because he did not want to be falsely accused of performing the procedure. His testimony showed that he knew about Roberts' abortion, treated her for it, tried to conceal it. ${ }^{117}$

Like Metcalf, Dr. Stapp testified that he had nothing to do with Roberts' surgery. He also claimed that he saw Roberts only after she had experienced a miscarriage. She was quite ill, especially because she had received no medical care for about a day, he told the jury. Stapp gave Roberts opium, quinine, and alcohol to ease her pain, he testified, but he never saw her before or after that date. According to Stapp, just like Metcalf, he had nothing to do with Roberts' abortion. If the testimony of both of these physicians were to be believed, another, unknown physician must have performed the abortion and Mrs. Stemp, the boardinghouse keeper, and Carrie Vanderbrugge, a resident of the boardinghouse, lied to the coroner and jury.

The coroner's jury rejected the testimony of Metcalf and Stapp. The jurors believed instead the statements of Stemp and Vanderbrugge, who testified that both physicians had treated Roberts and that Stapp had performed the abortion, and rendered a verdict of homicide. They determined that Annie Roberts had died from peritonitis, caused by a deadly injury "by the hand or hands of D. William Stapp, who ... inflicted the above mentioned fatal injury upon the deceased with an instrument, with the intention of producing an abortion." The jury named Metcalf as an accessory to the crime. Roberts was not blamed for the abortion, even though she had gone to Metcalf for a drug-induced abortion and to Stapp for a surgical one. The coroner's jury also made no mention of the

117 "Sin and Death." 
two women who knew about Roberts's abortion and tried to conceal it after she died. Metcalf and Stapp were arrested after the inquest concluded. ${ }^{118}$

The St. Louis press covered the inquest and vilified the physicians in a lengthy article, unlike in its accounts of women who died from abortions that they performed on themselves. Like coroners and their juries, journalists often ignored the fact that women like Roberts willingly sought abortions, treating them as victims of rogue doctors. In the case of Annie Roberts, a news reporter for the St. Louis Globe-Democrat sided with the coroner's jury and the grand jury in holding Stapp and Metcalf accountable for her death. Surprisingly, the reporter did not focus on Roberts's status as an unwed mother who was pregnant out of wedlock for a second time. Nor was she denigrated as a selfish woman who sought to avoid her responsibilities as a mother. The news accounts instead focused on William Stapp and Stephen Metcalf, while treating Roberts as a victim of doctors who preyed on women such as her for their own profit.

The Globe-Democrat attacked both physicians' professionalism, character, and even physical appearance. Their reporter claimed that Stapp's demeanor "lent an additional repulsiveness to a countenance of an exceedingly unattractive character." Even his dress and grooming reflected his immorality, as "his clothing and person were filthy in the extreme." If his supposed poor hygiene were not enough to assure readers of Stapp's guilt, the reporter added that he acted nervously when he took the stand to testify. Metcalf, like Stapp, was said to wear "shoddy and seedy" clothing. According to the

${ }^{118}$ Roberts Inquest; "Sin and Death." 
news account, Metcalf was a "quack" who lacked formal medical training, gave conflicting statements, and was "unprofessional" on the stand. ${ }^{119}$

The reporter displayed sympathy, however, for Annie Roberts. Although the title of the Globe-Democrat's article, "Sin and Death," suggests a harsh judgment of Roberts, the subtitle refers to her as an "Unhappy Woman" who "Sacrifices Herself to the Fear of Exposure." In contrast to the portrayal of the physicians, the reporter's coverage of Roberts spoke of the love that her fiancé had for her and recounted the testimony given at her inquest without remarks about her affairs, pregnancy, and abortion aside from the facts of the case. Compared to contemporary news accounts of the deaths of women who worked as prostitutes or of men and women who committed suicide, the reporter's restraint is unexpected. Reporters tended to be sympathetic toward women who had abortions, however, especially when they obtained them from midwives or physicians. ${ }^{120}$ The press attacks against Stapp and Metcalf were typical of news reports of deaths attributed to abortions performed by physicians. Although Stapp was a welltrained and experienced doctor, reporters treated him and his colleagues who performed abortions as professional pariahs. When the St. Louis Post-Dispatch and St. Louis GlobeDemocrat wrote about the perceived problem of abortion, they named the physicians

119 "Sin and Death."

${ }^{120}$ Ibid. A few months later when a woman named Mary Baum, who worked as a prostitute, died after a self-induced abortion, the Globe-Democrat mentioned her death only briefly, noting that she lived in a "house of ill-fame." Mary Baum Inquest, November 3, 1881, case no. 516, folder 117, box 27 (Missouri State Archives microfilm roll C31278), St. Louis City Office of the Coroner-Inquests 1845-1900, Missouri State Archives, Jefferson City; "Locals in Brief," St. Louis Globe-Democrat, November 3, 1881, 6. One can easily find accounts of suicides in St. Louis newspapers. For one example of a prostitute who committed suicide and received harsh judgment from the press, see Lucy Baird Inquest, July 10, 1898, case no. 302, folder 103, box 110 (Missouri State Archives microfilm roll C31304), St. Louis City Office of the Coroner-Inquests 1845-1900, Missouri State Archives, Jefferson City, hereafter referred to as Baird Inquest; "Veil Lifted at Death," St. Louis Post-Dispatch, July 10, 1898, 8; "Cora Kirk's Suicide," St. Louis Globe-Democrat, July 10, 1898, 24; Missouri Death Records, 1834-1910, Ancestry.com. Other examples are discussed later in this essay, but one already cited is the McClure Inquest; "Splinters," St. Louis GlobeDemocrat, July 30, 1881, 3. 
responsible and often sympathized with their patients. For example, in 1876 a Post-

Dispatch reporter wrote that W. W. Jilz seduced a young female employee and then gave her drugs to induce an abortion when she became pregnant. In court the prosecuting attorney, Charles P. Johnson, successfully made the case that Jilz was, in the words of the reporter, "an abortionist," “murderer," “social leper," and "destroyer of reputation.,"121

The jury convicted Jilz of criminal abortion. Other news accounts are similar, and some even note how difficult it was to get women to testify against doctors who performed abortions. Ellen Singer was one such reluctant woman. She became ill after an abortion and had to briefly stay in the Female Hospital. Shortly after the hospital released her, she was arrested and jailed to coerce her to testify against Charles A. Smith, the doctor who had performed her abortion. The Post-Dispatch reporter gleefully wrote that the "Doctor" was arrested and charged with manslaughter for performing an abortion on Singer, even though she did not wish to press charges and had fully recovered from the procedure. In virtually every case, the reporter focused on the misdeeds of physicians who performed abortions, not on the women who sought them. As the coverage of Smith illustrates, reporters even questioned the physicians' medical credentials, often putting the term "doctor" in quotes to indicate that they were not respectable members of the medical profession. $^{122}$

121 "Justice at Last: Jilz, the Abortionist, Behind the Bars of the County Jail," St. Louis PostDispatch, August 9, 1876, 2. Johnson was a prominent St. Louis attorney who had served as Missouri's lieutenant governor from 1873 to 1875 .

122 There were numerous examples of this kind of coverage. For a few examples, see: "Charged with Manslaughter: Doctor Charles A. Smith's Criminal Malpractice-Interview with the Prisoner," St. Louis Post-Dispatch, December 17, 1879, 4; "Obscene Literature: The Secret Circulation of Vile Books in St. Louis," St. Louis Evening Post, March 6, 1878, 2; "Justice at Last: Jilz, the Abortionist, Behind the Bars of the County Jail," St. Louis Post-Dispatch, August 9, 1876, 2; The Truant Witness: Ellen Singer, the Missing Witness in the Dr. Smith Case, Safely Caged," St. Louis Post-Dispatch, January 17, $1880,8$. 
Despite the scandalous newspaper coverage of Stapp and Metcalf's involvement in the death of Annie Roberts and a guilty verdict from the coroner's jury, neither physician served much prison time. St. Louis officials did not charge Metcalf with any crime, although Coroner Auler's jury deemed him an accessory to murder. Stapp was indicted for manslaughter, not murder, in 1879. He initially pled not guilty to the charge, but then changed his plea in order to receive a shorter sentence. Stapp served sixty days in the Work House for his conviction on the charge of criminal abortion rather than the four months in the city jail he would have served for manslaughter. ${ }^{123}$

This outcome for Metcalf and Stapp illustrated how difficult it was to prosecute abortion cases. To convince a jury that a physician had performed a criminal abortion, a prosecutor needed to obtain evidence, which was no simple task, particularly if a woman recovered with no health issues. When officials pressed charges, investigators needed testimony that someone had provided the abortion, with the strongest statement often coming from the patient. When women became ill after an abortion and had to stay in the Female Hospital, officials encouraged or even coerced them to testify against their treating physicians. When women died from abortions, coroners interviewed witnesses to learn the names of the physicians or midwives who had performed them, as Auler did in the death of Annie Roberts. ${ }^{124}$

${ }^{123}$ St. Louis City Circuit Court, Criminal Court Record Book 20:203, 205.

${ }^{124}$ Roberts Inquest. Officials often spent days, weeks, or months trying to locate physicians who performed abortions that caused the death or illness of their patients. For examples, see "Justice at Last: Jilz, the Abortionist, Behind the Bars of the County Jail," St. Louis Post-Dispatch, August 9, 1876, 2; "Charged with Manslaughter: Doctor Charles A. Smith's Criminal Malpractice-Interview with the Prisoner," St. Louis Post-Dispatch, December 17, 1879, 4; "Hard to See: How Dr. Fitzporter Manages to Evade the Law's Clutches," St. Louis Post-Dispatch, October 17, 1884, 2; “A Serious Charge: Coroner Nidelet Swears to the Warrant Against Dr. Rutledge," St. Louis Post-Dispatch, December 31, 1884, 5. One article discusses the difficulty of prosecuting even well-known abortionists: "The Secret Twelve: Subjects to Which Their Attention Will Be Called by Judge Laughlin," St. Louis Post-Dispatch, May 16, 1882, 4. Mohr, Abortion in America, 120-24, Reagan, When Abortion Was a Crime, 114-18. 
In some cases, coroners did not even investigate suspicious deaths because they simply did not have enough evidence. For example, Auler's successor as coroner, John N. Frank, sought to stop Stapp from performing abortions, but struggled to find enough evidence to give to the prosecutor. Four years after Annie Roberts died, Stapp faced another coroner's investigation and possible charges. In 1882 he performed an abortion for thirty-one-year-old Rosina Eichilz, a wife and mother of six. Instead of recovering quickly from the procedure, Eichilz suffered incredible pain, which Stapp treated with morphine. He assured her husband that many women in similar instances recovered, but Eichilz's symptoms did not improve. She died a few days after the operation. Her family physician, a Dr. Ehrhardt, learned of his patient's death and became suspicious. $\mathrm{He}$ looked at the death certificate, which stated that Eichilz died from "congestion of the lungs." Ehrhardt told Frank about the false death certificate and demanded that he conduct an inquest, but Frank lamented that while he knew Stapp was an abortionist and wanted to "catch him" for his crimes, he did not have enough evidence to warrant an inquest. A postmortem examination would show that Eichilz had had an abortion, Frank conceded, but he had no proof that Stapp had been the person to perform the procedure. Rosina Eichilz had made no statement that implicated Stapp, no one had seen her go to his office, and Stapp had not prescribed any suspicious medications such as abortifacients. Concealing abortions, even when patients died from them, was evidently a fairly common practice in late nineteenth-century St. Louis. ${ }^{125}$

Coroner Frank had reason to be cautious about sending abortion cases to prosecutors: a few months earlier he had faced a lawsuit for one zealous investigation. A

125 "Many Such: Sad Case of Abortion and Morphine Poisoning," St. Louis Post-Dispatch, September 5, 1882, 7. 
midwife sued him after he obtained a warrant for her arrest for performing an abortion. The patient became ill after the procedure, but recovered, and although she initially testified that the midwife performed an abortion, she later recanted and denied having been pregnant. Two years later, in 1884, Frank struggled to aid in the prosecution of another abortionist, a Dr. McWilliams. He interviewed a woman who became sick after receiving an abortion from McWilliams and gave the case to the prosecutor. McWilliams's defense attorney demanded a hearing and claimed that Frank had blackmailed his client because he wanted to bolster his reputation by bringing an abortionist to justice. The case ultimately went to trial, but only after a hard-fought battle. $^{126}$

While coroners such as Frank struggled to overcome the constraints against prosecuting abortions, physicians continued to perform the procedures regularly. William Stapp was just one of many physicians who served women seeking abortions. His medical practice was listed in the St. Louis city directory from the 1870 s until his death in 1892; he was not hidden. Women knew they could seek abortions from him, coroners investigated him when women died, and city officials indicted him, but he and other abortionists spent little time in jail. Like other abortion providers, Stapp hired skilled defense attorneys to defend him from criminal charges. Newspapers wrote stories about Stapp whenever he faced more charges for malpractice and performing abortions, but he continued to offer his female patients his services both in delivering their babies and

126 "Case Against the Coroner," St. Louis Post-Dispatch, January 3, 1882, 2; "The McWilliams Case: A Heated Discussion Between the Coroner and an Attorney," St. Louis Post-Dispatch, August 1, $1882,4$. 
terminating their unwanted pregnancies. He continued his practice well into old age, dying at eighty-one in $1892 .{ }^{127}$

There is no known biography of Stapp, and he and other abortion providers in St. Louis appear not to have offered any discussion in newspapers or professional journals of why they performed these procedures. Historians can only speculate as to why William Stapp felt compelled to perform abortions sought by young women. Perhaps he sympathized with women who wanted to limit their families because his own wife gave birth to nine children. As an obstetrician and gynecologist, Stapp saw women like Annie Roberts in distress and desperate to end their pregnancies. Some became so distraught about unwanted pregnancies that they committed suicide, as one young woman, Annie Sophie Wiegmann, did when the father of her unborn baby refused to marry her or even admit that he was the father. In Stapp's practice, he saw women with difficult pregnancies, women with more children than they could care for, and women for whom a pregnancy outside of wedlock would destroy their reputations and, accordingly, their opportunities for marriage, financial and emotional support from their families, or

${ }^{127}$ Gould \& Aldrich's Annual Directory of the City of St. Louis, for 1872 (St. Louis: Review Steam Press, 1872), 716; Gould's St. Louis Directory for 1874 (St. Louis: David B. Gould, 1874), 847; Gould's St. Louis Directory for 1880 (St. Louis: David B. Gould, 1880), 981; Gould's St. Louis Directory for 1889 (St. Louis: Gould's Directory Co., 1889), 1209; Gould's St. Louis Directory for 1892 (St. Louis: Gould's Directory Co., 1892), 1462; "The New Grand Jury: It Is Sworn In This Morning and Mr. Nathan Cole Made Foreman," St. Louis Post-Dispatch, July 7, 1890, 3; "Trials for Homicide: Fourteen of Them Docketed for the Coming Term," St. Louis Post-Dispatch, January 4, 1891, 11. Interestingly, Charles P. Johnson, who had prosecuted a known abortionist, W. W. Jilz, in 1876, defended Stapp in the 1890s. "Justice at Last: Jilz, the Abortionist, Behind the Bars of the County Jail," St. Louis Post-Dispatch, August 9, 1876, 2; "Four Courts Notes," St. Louis Globe-Democrat, Tuesday, July 15, 1879, 4. Stapp performed an abortion upon Jennie Sanders, a "young negress," which resulted in her death four months after Roberts's death. For Stapp's death, see Missouri, Death Records, 1834-1910, accessed January 23, 2016, Ancestry.com. He is buried in Bellefontaine Cemetery. Randal Nichoalds, "Dr William Stapp," accessed January 23, 2016,

http://www.findagrave.com/cgibin/fg.cgi?page=gr\&GSln=Stapp\&GSiman=1\&GSst=26\&GSob=c \&GRid= $151266260 \&$. 
employment. Abortions performed by physicians were far safer than those performed by women on themselves, so Stapp and physicians like him may have agreed to them knowing that the women might otherwise risk their lives by taking matters into their own hands. Most of these women were wives and mothers, and their families needed them. While Stapp's exact reasons for performing abortions are unknown and may have been dishonorable, it is also possible that he simply wanted to help his patients. Whatever the motivation, his son, Samuel Stapp, also became an obstetrician and gynecologist who performed abortions, for which he too faced public criticism and criminal charges. ${ }^{128}$

Most women survived and went on with their lives after they had abortions, particularly those performed by midwives or physicians, making the cases explored in this chapter unusual. Because it was illegal in the late nineteenth century, few records document the procedure, but it was fairly common. Most women who had abortions were married and already had children, much like Mrs. Kate McClure, and most quickly recovered from the procedure, as she had several times before. Ellen Noonan, Mary Baum, and Annie Roberts were women who could have proven stereotypes about women who had abortions: they selfishly avoided motherhood, they were often unmarried, they were prostitutes, or they were victims of men who seduced them and then refused to marry them. But they gained little press attention and even sympathy, particularly Roberts, because a known abortion-providing physician ended her pregnancy and she died as a result, the coroner's jury, prosecutor, and St. Louis press treated her as a

\footnotetext{
128 "Sin and Death." Stapp had twelve children with two women. His first wife, Mary, was the mother of nine of his children. US Federal Census, 1850, 1860, and 1880, accessed January 23, 2016, Ancestry.com; Annie Sophie Weigmann Inquest, July 23, 1884, case no. 1079, folder 79, box 39 (Missouri State Archives microfilm roll C31282), St. Louis City Office of the Coroner-Inquests 1845-1900, Missouri State Archives, Jefferson City; "News from Missouri," Potosi Journal, March 1-3, $1902,1$. Samuel Stapp was arrested in March 1902 for performing an abortion on seventeen-year-old Essie Howard.
} 
victim - a different stereotype of women perpetuated by members of the medical profession. While physicians created abortion laws in the mid-nineteenth century to regulate their profession and protect women's health, later generations of doctors would point to cases like Baum's, McClure's, and Roberts' as evidence that anti-abortion laws were not only ineffective, but harmful. Physicians like Dr. Stapp, who performed abortions and treated women who had them, listened to their women patients and helped lead a new movement in the mid-twentieth century to make abortion safe by making it legal. 


\section{Chapter Four \\ Desperate Deeds and Murderous Plots: Homicide Verdicts}

Gunshots startled the residents of St. Louis' Girard House around 1:00 on the afternoon of August 17, 1878. Residents heard four shots fired in in rapid succession and some also heard a body fall. A crowd rushed to the locked room belonging to Josiah and Lillie Colcord. When several men forced the door open, they saw the Colcords lying on the floor. Twenty-two-year-old Lillie Colcord had three gunshot wounds: one each in her chest, stomach, and thigh. Thirty-five-year-old Josiah had a single gunshot wound to his head. Dr. James C. Nidelet responded in hopes of treating the pair's injuries, but the couple died before he even arrived. Instead of a physician, a coroner needed to respond to the scene, and Coroner Hugo Auler did so. He concluded that Josiah Colcord shot and killed his wife before killing himself. ${ }^{129}$

In addition to the gunshot wounds, Coroner Auler found other injuries on Lillie that reveal evidence of domestic violence. He found suspicious bruises that were not caused by the shooting: one on her nose, above her left eyebrow, and on her right arm. Witness testimony indicated that Josiah had a history of beating Lillie, but domestic violence was not the focal point of the death investigation and was completely ignored by

${ }^{129}$ Josiah P. Colcord Inquest, August 14, 1878, Case No. 877, Folder 63, Box 15 (Missouri State Archives microfilm roll C31274), St. Louis City Office of the Coroner-Inquests 1845-1900, Missouri State Archives, Jefferson City, Missouri; Lillie Colcord Inquest, August 14, 1878, Case No. 17, Folder 156, Box 12 (Missouri State Archives microfilm roll C31274), St. Louis City Office of the Coroner-Inquests 1845-1900, Missouri State Archives, Jefferson City, Missouri. Hereafter both will be referred to as "Josiah Colcord Inquest" and "Lillie Colcord Inquest." The testimony is missing from these inquests, but was printed in its entirety in a newspaper: "Wine and Women," Daily Rocky Mountain News, Sunday, August 18, 1878, 1. J.C. Nidelet was the brother of Coroner Sylvester Nidelet. He often performed autopsies when his brother was coroner. 
the St. Louis press. Instead, the press blamed Lillie for her own murder because they understood the once-prominent lawyer to be a respectable man who had been seduced and fallen from grace because of Lillie, a former prostitute. Josiah Colcord is an example of the tendency for the public to sympathize with some perpetrators of homicides - when they were respectable men and women, white, and middle to upper-class. ${ }^{130}$

Josiah Colcord was just one perpetrator of a homicide who struggled with their victims over power, status, and, in some cases, lovers. Colcord was typical in that most perpetrators of murder-suicides were men as were most abusive spouses. Although men were more likely to commit murder-suicides and homicides in general than were women, as this chapter will show, men and women had similar motives for killing others and faced similar treatment in courts and from the press, particularly African American men and women, who faced stricter charges and harsher criticism than did their white counterparts. Despite the fact that more white men and women committed homicides than did black men and women, black men and women were judged more harshly for committing homicides and often faced longer prison sentences than did whites, particularly black men. ${ }^{131}$ Just as in other death investigations, witnesses, coroners, coroners' juries, and, especially, newspaper reporters were more likely to sympathize with both perpetrators and victims of homicides if they understood them to be respectable, particularly if they were white. The assumptions about the reputation of the deceased and the perpetrators of homicides shaped the investigations and interpretations

${ }^{130}$ Wine and Women," Daily Rocky Mountain News, Sunday, August 18, 1878, 1; "Ruined by Rum," St. Louis Globe-Democrat, Sunday, August 18, 1878, 1; "Post Office Corners," St. Louis GlobeDemocrat, Monday, August 19, 1878, 4.

${ }^{131}$ Four African American men and women in this study died by homicide, a smaller number than those who died by accidental or natural deaths (seven and five, respectively), but a larger number than those who died by suicide (one), alcoholism (two), or abortion (zero). 
of these deaths. Respectable St. Louisans garnered the sympathy of others even when they committed murder. In some cases, the press even blamed the victims for their murders when their killers had been respectable, prominent residents of the city. ${ }^{132}$

Most of the men and women who committed homicides were not understood to be respectable, however, and received little or no sympathy or explanations for why they committed these acts. Just as most of the other men and women in this study, most of the murderers tended to be working-class or poor and native-born white or recent immigrants. Several perpetrators of homicides were African American, however, and because homicides received more press coverage than other causes of death and because homicide verdicts led to criminal charges it is possible to contrast the treatment of blacks and whites. Racist language appears in press coverage of black killers and both black men and women tended to receive quicker criminal verdicts and harsher verdicts than did their white counterparts, especially evident in cases of domestic violence. In addition to race and class, the occupations and neighborhoods of many of these killers made them disreputable in the views of the white middle class. Several men were roustabouts on steamboats or worked in machine shops_-jobs that were associated with the "rough" working-class. Some of the women were serving time in the Work House. Other women had worked as prostitutes or had in the past and had prior marriages and divorces. Some of these white women also married black men and lived in black neighborhoods as well.

${ }^{132}$ Much has been written about the history of homicide, particularly with attention to race, class, and gender. For important monographs in the field, see: Roger Lane, Violent Death in the City: Suicide, Accident, and Murder in Nineteenth Century Philadelphia (Cambridge: Harvard University Press, 1979); Jeffrey Adler, First in Violence, Deepest in Dirt: Homicide in Chicago, 1875-1920 (Cambridge: Harvard University Press, 2002); Randolph Roth, American Homicide (Cambridge: Belknap press of Harvard University Press, 2009). 
Not only were these men and women perceived as having questionable reputations by white middle-class reporters, but they were also isolated from others, just as many men and women who died from suicides, alcohol and/or drugs, and abortions were. While these men and women had friends, relatives, and acquaintances to testify before the coroner, they were often not close with these people, meaning that they often had no one to try to understand and explain their motives for killing others. The few men and women who did have close friends, relatives, or coworkers received much more sympathy from witnesses and the press than did their isolated counterparts.

Homicide cases are unique because men are overwhelmingly represented in these cases as murderers. Few women killed others, but when they did, their motives were often the same as those of men - particularly conflicts over power. Of the fourteen cases in this chapter, only two perpetrators of homicide were women. In part, this could be because women were more likely to commit infanticide than to kill other adults. When women did kill others, they often killed their husbands, but as this chapter illustrates, despite these historical trends, women had a variety of motives and victims, just as men did. ${ }^{133}$

The cases in this chapter also demonstrate that the justice system in St. Louis in the late nineteenth century was complex. Because the coroners suspected homicides in these cases, they held formal jury inquests in every case. In these cases, coroners questioned witnesses before a jury of six white male state residents, who ultimately rendered a verdict regarding the cause of death, rather than the coroner. While the

${ }^{133}$ Jeffrey Adler, "I Loved Joe, but I Had to Shoot Him': Homicide by Women in Turn-of-theCentury Chicago," The Journal of Criminal Law and Criminology 92, no. 3/4 (Spring-Summer, 2002): 873. Women were more likely to commit infanticide than were men, but this study focuses on men and women who died between the ages of twenty and fifty, not children who died. 
coroner and his jury determined if a man or woman should be held legally responsible for taking the life of someone else, they did not have complete power. The coroner could only recommend charges and seek warrants for arrests and charges; a judge and jury had to decide the fate of these men and women who committed homicides. An investigating coroner and his jury could determine that a man or woman intended to kill someone only to have a judge believe that the person acted in self-defense or the heat of the moment. The coroner and his jury sought to determine the intent of men and women who killed someone. Verdicts ranged from "accident" to "justifiable homicide" to "homicide" with the names of the perpetrators and accomplices.

While coroners' juries worked to determine a killer's intentions, the charges that a killer received depended on the evidence presented in the case, the judge, and attorneys. The verdicts rendered by coroners' juries were not always maintained in courts of law and, in fact, were often lowered, sometimes by prosecutors who made plea deals with defense attorneys, just as they do today. While every defendant in this chapter was poor to working-class, race contributed to their charges and sentences. African American men and women were tried quickly and faced tougher charges and sentences than their white counterparts, including working-class and immigrant white men. ${ }^{134}$

Men who avoided a courtroom by committing suicide were still judged for their acts, but friends, relatives, coworkers and, especially the press interpreted these crimes differently based on class, race, and reputation. Three homicides in this chapter feature

${ }^{134}$ Oscar T. Schultz and E.M. Morgan, "The Coroner and the Medical Examiner," in Bulletin of the National Research Council Nos. 64-66 (Washington, D.C.: July, 1928): 24; Herbert S. Breyfogle, "The Laws of Missouri Relating to Inquests and Coroners," Missouri Law Review 10 (1945), 38-39, 43; McIlroy, Jr., 21; Jeffrey M. Jentzen, Death Investigation in America: Coroners, Medical Examiners, and the Pursuit of Medical Certainty (Cambridge, Mass.: Harvard University Press, 2009), 35. 
evidence of domestic violence. Wives were a common target for men, particularly in cases of domestic violence, as three cases illustrate. Two of the men killed themselves after murdering the women they supposedly loved while the third faced murder charges. All three deaths gained the attention of neighbors, relatives, and the press, but the reputation, race, and class of both the murderers and their victims shaped how these murder-suicides were investigated and interpreted.

The murder-suicide of Josiah and Lillie Colcord is remarkable because the St. Louis press blamed Lillie for her own murder and overlooked evidence that Josiah abused her. Local reporters because that Josiah was respectable while his wife, Lillie, was disreputable, having formerly worked as a prostitute. The press also sought to find an explanation for the tragic murder-suicide, even claiming that Josiah was drunk, although there was no evidence for this. In fact, Josiah had been declining personally and professionally for several years. His first wife, Mary, divorced him five years earlier, probably because he drank heavily. Josiah had also lost his job as an attorney and lived with his second wife, Lillie, in a boarding house at the time of his death. While the St. Louis press and some of his former colleagues believed Josiah to be a respectable man whose act must be explained, witnesses did not share the reporters' sympathy and believed the murder-suicide to be the act of a man who had fallen from grace some time before. ${ }^{135}$

135 Josiah P. Colcord Inquest, August 14, 1878, Case No. 877, Folder 63, Box 15 (Missouri State Archives microfilm roll C31274), St. Louis City Office of the Coroner-Inquests 1845-1900, Missouri State Archives, Jefferson City, Missouri. The testimony is missing from this inquest, but details of the murder-suicide, including some information from the inquest, were printed in newspapers: "Ruined by Rum," St. Louis Globe-Democrat, Sunday, August 18, 1878, 1; “Wine and Women," Daily Rocky Mountain News, Sunday, August 18, 1878, 1. 
The coroner's inquest into the murder-suicide discussed in the opening story reveals evidence of domestic violence. When Coroner Hugo Auler conducted his investigation, he found bruises that were not from the shooting and also talked to witnesses who told him that Josiah beat his wife. Lizzie Jeffries, a chambermaid at the Girard House, told the coroner that the couple fought often and Lillie had even told her that "Colcord treated her badly and she intended leaving him." Lizzie spotted an injury in Lillie's arm and asked Lillie, "“if that was the way she was treated?"” and Lillie replied, "'Yes, and worse than that sometimes." Other chambermaids did not know that the couple quarreled, but did mention that they kept to themselves, taking meals in their rooms and not leaving much shortly before their deaths. ${ }^{136}$

Reporters and the people they talked to blamed Lillie for the murder-suicide because he had a sterling reputation and she had a tarnished one. Lillie had been married three times, worked as a prostitute for a period, and, evidently, had recently traveled to Illinois where she may have had an affair. A Globe-Democrat reporter spoke to someone who blamed Lillie for the deaths not because of her character, but because of her infidelity. Mr. Nat. C. Claiborne, said, "'I think when he [Josiah] went to the room in the Girard House yesterday afternoon he saw evidences which persuaded him she had been unfaithful, and determined to end his troubles then and there, after he had sated his vengeance on her."'137 Lillie had, in fact, recently traveled to her hometown where she may have had an affair and, perhaps, been planning to leave Josiah, but that is speculation. Other reporters claimed that Josiah was drunk when he killed Lillie and then

136 Wine and Women," Daily Rocky Mountain News, Sunday, August 18, 1878, 1; Colcord Inquest; "Ruined by Rum," St. Louis Globe-Democrat, Sunday, August 18, 1878, 1.

137 "Post Office Corners," St. Louis Globe-Democrat, Monday, August 19, 1878, 4. 
himself, claiming that there was rum or wine in the room at the time of the murder-

suicide, but there is no corroborating evidence to support this. Reporters in St. Louis and elsewhere sought an explanation for the surprising tragedy that did not require them to blame Josiah. ${ }^{138}$

Residents of St. Louis did not share reporters' sympathy for Josiah. Few attended his funeral and a few also requested that newspapers correct previous statements that they were associated with him. Finally, his colleagues held a meeting to honor Josiah in some way, but only met briefly and left without creating a memorial for him. While reporters, particularly for the Globe-Democrat sympathized with Josiah, the people who knew him best did not. Josiah had been prominent in St. Louis ten years before, but not when he died, and the fact that he killed his wife and then himself was inexcusable to the people who knew him best. ${ }^{139}$

What few witnesses and reporters acknowledged was that Josiah abused Lillie and the murder-suicide resulted from domestic violence. The act itself suggests this, as do the bruises on Lillie and her statements to the chambermaid. Witnesses and reporters eagerly sought explanations that exonerated Josiah, or at least explained the violent act, namely alcohol and Lillie herself. They pointed to a diary found in the couple's room

\footnotetext{
138 Although several newspaper accounts claim that Josiah was drunk when he killed Lillie and himself, there is no evidence to support this. "All the Blue-Ribbon Movements...," St. Louis GlobeDemocrat, Sunday, August 18, 1878, 4; "Personal Intelligence," The North American, Monday, August 19, 1878, 1; "Ruined by Rum," St. Louis Globe-Democrat, Sunday, August 18, 1878, 1; "Wine and Women," Daily Rocky Mountain News, Sunday, August 18, 1878, 1; "Post Mortem Points," St. Louis GlobeDemocrat, Tuesday, August 20, 1878, 4; "Under the Sod," St. Louis Globe-Democrat, Monday, August 19, 1878, 8; "Post Office Corners," St. Louis Globe-Democrat, Monday, August 19, 1878, 4; "Funeral Notice," St. Louis Globe-Democrat, Wednesday, August 21, 1878, 5; "St. Louis in Splinters," St. Louis GlobeDemocrat, August 21, 1878, 8; "Funeral of Lillie Colcord," St. Louis Globe-Democrat, Thursday, August 22, 1878, 8. Local prostitutes created a fund to pay for Lillie's funeral and burial.

139 “A Card," St. Louis Globe-Democrat, Tuesday, August 20, 1878, 7; "The Dead Lawyer," St. Louis Globe-Democrat, August 21, 1878, 7; "The Dead Lawyer," St. Louis Globe-Democrat, August 21, $1878,7$.
} 
that did not mention any violence, but this alone is far from sufficient evidence that the couple was happy. The bruises on Lillie that did not come from the fatal shots, the couple's refusal to leave their room, and Lillie's statements to Lizzie, the chambermaid, all indicate that the murder-suicide was part of a history of Josiah's abuse of Lillie. The fact that she may have recently traveled and had an affair-perhaps part of plans for her to leave him — could have triggered jealousy and violence on Josiah's part. Because of his supposed sterling reputation and her tarnished one, however, no one explained their deaths in this way. ${ }^{140}$

Newspaper reporters did not seek to excuse the violent acts of Clarence Ward, who killed his common-law wife, Maria Sutton, and then himself. Unlike Josiah Colcord, Ward and his wife were both African American and working-class. The couple also had a common-law, rather than legal, marriage. Because they were African American, newspapers mentioned and focused on their race, unlike in their reports of the deaths of white men and women. On the night of September 14, 1875, around 9:30 p.m., Clarence Ward, a thirty-four-year-old painter, and twenty-four-year-old Maria Sutton, had an argument that turned violent. Sutton was allegedly having an affair with another man, John Finley, and Ward confronted her that night and ordered her to stop seeing him.

${ }^{140}$ Lillie and Josiah Colcord Inquests; Wine and Women,” Daily Rocky Mountain News, Sunday, August 18, 1878, 1.

For more on domestic violence, see: Jeffrey Adler, "We've Got a Right to Fight; We're Married': Domestic Homicide in Chicago, 1875-1920; Jeffrey Adler, "If We Can't Live in Peace, We Might as Well Die": Homicide-Suicide in Chicago, 1875-1910, Journal of Urban History 26, no. 3 (Nov. 1999): 3-21; Pamela Haag, “The 'Ill-Use of a Wife:' Patterns of Working-Class Violence in Domestic and Public New York City, 1860-1880." Journal of Social History 25, no. 3 (Spring, 1992): 447-477; Elizabeth Pleck, Domestic Tyranny: The Making of Social Policy Against Family Violence from Colonial Times to the Present (New York: Oxford University Press, 1987); Gordon, Linda. Heroes of Their Own Lives: The Politics and History of Family Violence: Boston, 1880-1960. New York: Viking, 19881 Kirsten S. Rambo, "Trivial Complaints:" The Role of Privacy in Domestic Violence Law and Activism in the U.S. (New York: Columbia University Press, 2009). 
Sutton refused to acquiesce to his demands and yelled, "'If you don't hold your tongue I'll leave." "141 Moments later, neighbors heard two shots fired quickly together. Soon after, a police officer forced his way in to the couple's apartment and found the couple dead on the floor. Ward shot Sutton in the head before shooting himself in the heart. Sutton's four-year-old-son slept nearby, evidently not awakening from the commotion. He was taken to Four Courts until a new home could be found for him. ${ }^{142}$

Newspaper reporters, friends, and neighbors did not have to guess why Clarence Ward killed his wife and himself because he left a letter explaining his acts. He sought revenge and to escape an execution for his crimes. He had written the letter nine days earlier, showing that he had planned the murder-suicide and had also planned to kill Sutton's alleged lover. He wrote: "“I hope you will all excuse and forgive me for this rash and violent act I have done to others and myself." ${ }^{143}$ Ward then detailed Sutton's alleged affair with John Finley. Clarence said, "'She is not fit to live. She shall not live to deceive another." While Ward claimed that Sutton's affair with Finley was the reason for his violence, Finley denied having a romantic relationship with Sutton. Finley even wrote to the local newspaper to claim that he and Sutton were mere acquaintances, in hopes of preserving his reputation. While it is unknown whether Sutton and Finley had an affair or if Clarence Ward simply believed that they did, Ward's motives were clear, as was his lack of remorse over the killings. Ward did not commit suicide because he regretted killing Sutton, according to his letter, but rather to avoid being hanged for

\footnotetext{
141 “Murder and Suicide," St. Louis Globe-Democrat, Wednesday, September 15, 1875, 4.

${ }^{142}$ It is unknown what happened to Suttons' son. Clarence Ward, September 15, 1875, Case No. 452, Folder 53, Box 7 (Missouri State Archives microfilm roll C31272), St. Louis City Office of the Coroner-Inquests 1845-1900, Missouri State Archives, Jefferson City, Missouri; "Murder and Suicide," St. Louis Globe-Democrat, Wednesday, September 15, 1875, 4. The testimony is missing from the inquest, so details about the murder-suicide come from newspaper accounts.

143 “Murder and Suicide," St. Louis Globe-Democrat, Wednesday, September 15, 1875, 4.
} 
killing her. He had also planned to kill Finley, but did not, perhaps because his rage prompted him to kill Sutton and himself after a fight, rather than find a way to kill both his wife and her alleged lover. Ward wrote that he expected to be caught and executed for murdering the pair. Ward did not apologize for the murder, nor did he mention the four-year-old-child whom he was raising. He wrote: "What I have done is in good faith, and if the same was to be done, I would do it ten times over. I tried to do all that a poor man could to make the woman and home happy, until it became a hell on earth to me. $" 144$

Unlike the Colcord murder-suicide, newspaper reporters did not excuse Ward's violent acts. Reporters across the Midwest blamed jealousy for Ward's double-shooting. Because the couple was black, every newspaper article mentioned their race, which they never did for white men and women. A Globe-Democrat reporter wrote of the visitors to the dead couple's apartment: "Hundreds of colored people, mostly women, of various hues, from the dark ebony to the light mulatto, congregated around the place, and thronged the stairs, the porch and the alley." The reporter added that the couple were both mixed-race, or, as they called them, "mulatto." Maria Sutton, the reporter claimed, had been married once and had also had several lovers, perhaps trying to explain Ward's jealousy and at least pointing out that she was no respectable woman. Her husband was the father of the four-year-old boy who was in the apartment during the shooting. The couple was buried in the Greenwood Cemetery with the expenses paid by the Masonic

144 "Murder and Suicide," St. Louis Globe-Democrat, Wednesday, September 15, 1875, 4; "Love's Madness," St. Louis Globe-Democrat, Thursday, September 16, 1875, 8; “John Finley's Story," St. Louis Globe-Democrat, Thursday, September 16, 1875, 4. 
Lodge, but the Masons refused to attend the services. While Ward was a member of the lodge, the Masons refused to even appear to sanction his acts. ${ }^{145}$

The largest, white-run St. Louis newspapers covered this murder-suicide far less than the Colcord case, likely because the couple was not white and were not prominent residents of St. Louis. ${ }^{146}$ Yet the two cases are similar. In each case, men presumably became jealous over presumed infidelities and shot and killed their wives. In addition, people who were mentioned in newspaper accounts of the deaths sought to distance themselves from the murderers by writing to newspapers to clear their names. In this case, John Finley wrote to the Globe-Democrat in hopes of clearing his name. Finally, some friends and acquaintances of the murderer refused to attend the funeral of Ward, just as many did for Josiah Colcord. There is no evidence of domestic violence in the Ward-Sutton case, but there is also no testimony from the coroner's inquest remaining in the record, which may have contained testimony from neighbors and relatives about the couple's relationship. Newspapers did not print the inquest testimony of the witnesses in this case, so the coroner's findings in his investigation are unknown. Given the fact that Ward murdered Sutton, however, it is likely that he also beat her. ${ }^{147}$

145 “Love's Madness," St. Louis Globe-Democrat, Thursday, September 16, 1875, 8; "St. Louis in Splinters," St. Louis Globe-Democrat, Friday, September 17, 1975, 4; "The Courts," St. Louis GlobeDemocrat, Friday, September, 17, 1875, 3; "Love's Madness," St. Louis Globe-Democrat, Thursday, September 16, 1875, 8; "Murder and Suicide," St. Louis Globe-Democrat, Wednesday, September 15, 1875, 4; "Clarence A. Ward," Ancestry.com, Missouri, Death Records, 1834-1910; "Clarence A. Ward," St. Louis County, Missouri, Probate Court, Probate Case Files, 1802-1876, ancestry.com [accessed September 25, 2016].

146 An online database of black newspapers shows no coverage of the murder-suicide. The State Historical Society of Missouri does not have any black newspapers from this time period on microfilm, so more research must be done to determine how such murders were covered by the black press and how their coverage differed from that of white reporters.

${ }^{147}$ John Finley died of natural causes in 1886 and is buried in the same cemetery as Ward and Sutton. “John Finley,” Ancestry.com, Missouri Death Records, 1834-1910 [accessed September 25, 2016]. 
John Cordry faced similar public condemnation for murdering his common-law wife, Nellie Lee, and faced quick criminal charges and a strict sentence because he was a black man who married, abused, and killed a white woman. John Cordry, a thirty-threeyear-old African American or mixed-race man had abused thirty-five-year-old Nellie Lee, a white woman, for some time. In the wee hours of the morning on April 28, 1878, Nellie Lee went to a friend's house, that of Millie Squires, possibly to hide from Cordry or perhaps to seek care for injuries she had just received from a fight with another woman, Pinkey Daniels. While Lee's motivations for going to Squires' home are unknown, Cordry went looking for her there. When Squires said that Lee was not there, Cordry "said, 'You g-d d-n liar, she is in there." He then ran into the house and Squires tried to run out of the back door. Once inside, Cordry asked Lee to go home with him, but she refused, saying, "No; I'm afraid you'll beat me,"” or possibly “"Because I am afraid that you will beat me to death.'” Refusing to go home with Cordry did not save Lee from an assault, though, because Cordry hit her in the face, knocking her down. He then kicked and stomped her to death. When the coroner investigated Lee's death, he found her body to be badly bruised and the coroner's jury determined that she died from a "brain hemorrhage and colon gangrene," the result of blows not only from John Cordry, but also from Pinkey Daniels. ${ }^{148}$

Lee's beatings from Cordry and Daniels were apparently two unrelated incidents, but the coroner's jury determined that both caused Lee's death. Pinkey Daniels, a black

${ }^{148}$ Kicked to Death," St. Louis Post and Dispatch, April 29, 1878, 4; “A Brutal Crime,” St. Louis Post-Dispatch, July 3, 1878, 1. Nellie Lee Inquest, April 29, 1878, Case No. 29, Folder 8, Box 13 (Missouri State Archives microfilm roll C31276), St. Louis City Office of the Coroner-Inquests 18451900, Missouri State Archives, Jefferson City, Missouri. Lee's inquest records her as married as do most newspaper accounts, but I could not find a marriage record for her and Cordry. They may have had a common-law marriage. 
woman with a history of violence, attacked Lee in the alley just minutes before Lee went to Squires' house. Lee was bleeding from her left ear as a result of Daniels' attack. What caused the attack is unknown, because inquest testimony is missing and the newspapers focused on Lee's murder by Cordry. But Daniels faced criminal charges for "assault to kill," for which she pled "not guilty" and was acquitted. John Cordry also faced charges for killing his wife and, unlike Daniels, was found guilty and sentenced to ten years in the state penitentiary for second-degree murder. ${ }^{149}$

Newspapers lauded Cordry's quick trial and conviction, a process which took only two days, in part because of his brutal acts, but primarily because he was a black man. One Globe-Democrat reporter described Cordry as "a brutal-looking mulatto, about 30 years of age, lips thick and sensual, and covered with a small black moustache." Another Globe-Democrat reporter wrote: "More of this judicial expedition would be a good thing for the criminal class." For this reporter, the "criminal class" referred to African Americans as well as those who often committed crimes because he depicted Cordry as animal-like. He claimed that Cordry killed Lee "with his heavy hoof," not his foot or his fists. The reporter considered Cordry to be essentially sub-human, this statement reveals, and no newspaper account (or inquest testimony) depicts any white person as having the physical features of an animal. ${ }^{150}$

149 “A Brutal Crime,” St. Louis Post-Dispatch, July 3, 1878, 1. Pinkey Daniels appeared in the newspaper for other crimes: "Charges of Crime," St. Louis Globe-Democrat, Wednesday, December 11, 1878, 7; "The Courts," St. Louis Globe-Democrat, Wednesday, January 22, 1879, 7; "Walked Away from Suicide," St. Louis Globe-Democrat Wednesday, January 28, 1880, 8; “City Criminalities," The Daily Inter Ocean (Chicago, Illinois), Monday, June 19, 1882, 8; St. Louis City Circuit Court, Criminal Court Record Book Volume 20, 112, 139, 179-180; St. Louis City Circuit Court, Criminal Court Record Book Volume 19, 642, 662; Missouri State Penitentiary Database, Reel S216, Volume G, Page 31, Register No. 928 , Jno Cordry.

150 “Kicked to Death," St. Louis Post and Dispatch, April 29, 1878, 4; "Sharp Work," St. Louis Globe-Democrat, Thursday, July 4, 1878, 5. 
No reporter sought to explain Cordry's acts, unlike Colcord and Ward, who also killed their wives. Cordry did not leave behind any letters, unlike Ward, explaining why he killed Lee. And unlike Colcord, Cordry was not a once-respectable white man who had fallen from grace. Perhaps the reporters believed it was Cordry's nature as a supposed black man of the "criminal class" to beat and kill his wife. Or perhaps they believed that Lee's fear of his beating her showed that he was an abusive man and that explained the murder. Finally, Cordry could speak for himself and explain why he killed his wife, unlike Colcord and Ward, who killed themselves. Cordry made no statement at his trial, though. Regardless, the coverage of this murder differed from the murdersuicides because no one sought to explain, and certainly did not try to justify, Cordry's acts. Yet like Lillie Colcord, and perhaps Maria Sutton, Nellie Lee feared Cordry because he beat her. The fact that a black man killed a white woman also defied period race conventions, but reporters were neither sympathetic nor critical of Lee. The press did point out that she lived in an African American neighborhood (what reporters called a "negro den") and claimed that she had been "abandoned" by her husband, Frank Lee. Some suggested that she worked as or had once been a prostitute as well. Reporters for the Globe-Democrat cared far more about reporting the gruesome details of Lee's murder and the condition of her body than in understanding what caused her death. ${ }^{151}$

Men not only killed women over struggles of power and to prove their manhood, but they killed other men for these reasons as well, particularly when they were confined

151 "Kicked to Death," St. Louis Post and Dispatch, April 29, 1878, 4. 
in close quarters, often the workplace. Charles Koebel stabbed and killed two of his coworkers after fighting over a wash bucket at Gustave Griesche's machine shop in the early evening of January 31,1884 . Most men in the shop were young and many spoke German, as these three men did, all of whom were in their mid-twenties. Another coworker had retired or resigned from the shop that day and gave two men, Charles Meyer and Albin Berger, a wash bucket as a gift when he left. Evidently, Charles Koebel resented this gift, as he believed that the bucket was promised to him. Koebel was also a worker with more seniority and a more prominent position than Meyer and Berger, as an engineer and fireman who had worked at the shop for a year. Meyer and Berger were both lathe-workers who had only been employed for a few weeks. Despite his better position and seniority, Koebel was apparently less well-liked by his coworkers than Meyer and Berger. Meyer and Berger were partners at work and also lived together and had both had previous disagreements with Koebel. The argument over the wash bucket was the last and most violent fight among the three men. ${ }^{152}$

Koebel possibly felt threatened by Berger and Meyer as the two men confronted him together at the end of the workday, when their deadly fight began. Meyer and Berger claimed that Koebel had broken their wash bucket. One or both men allegedly punched Koebel and he then responded by pulling his knife and stabbing both men. By the time other men in the shop rushed to help, Koebel had stabbed both men repeatedly. Koebel ran from the scene and Meyer and Berger were taken to the Dispensary. Koebel was found and arrested the next day. Charles Meyer died the next morning because the stab

152 “A Fatal Affray,” St. Louis Globe-Democrat, Thursday, January 31, 1884, 12. 
wounds caused him to bleed to death, while Albin Berger died several days later from peritonitis from the stabbing. ${ }^{153}$

Coroner Sylvester Nidelet investigated Meyer's and Berger's deaths in two inquests to determine if Koebel was responsible. Several men saw the stabbing and fight, with some claiming they "scuffled" before the stabbing, another claiming that Koebel hit Meyer first, and still others testifying that they only saw the three men fighting. Several heard someone say, "One man is enough," probably referring to the fact that both Meyer and Berger were fighting with Koebel. All saw that Meyer and Berger had been stabbed when the fight ended, however, and saw Koebel holding a knife. Koebel was gone by the time the police and physician arrived. Some witnesses tried to tell Coroner Nidelet and his jury about an argument between the three men earlier in the day, but he steered the conversation to the stabbing itself. Despite some differences in testimony, it was clear that the three men had a physical altercation after arguing over a wash bucket which resulted in Koebel stabbing Meyer and Berger. These three men were not equals. Koebel may have held a better position and had worked at the shop longer, but Meyer and Berger worked together, lived together, and teamed up to confront Koebel that evening. Whether or not Koebel was in danger or even felt the need to defend himself, the fight was a struggle over power and perhaps status in the machine shop. ${ }^{154}$

${ }^{153}$ Charles Meyers Inquest, February 2, 1884, Case No. 708, Folder 66, Box 37 (Missouri State Archives microfilm roll C31281), St. Louis City Office of the Coroner-Inquests 1845-1900, Missouri State Archives, Jefferson City, Missouri; Albin Berger Inquest, February 7, 1884, Case No. 718, Folder 76, Box 37 (Missouri State Archives microfilm roll C31281), St. Louis City Office of the Coroner-Inquests 1845-1900, Missouri State Archives, Jefferson City, Missouri. Sylvester's brother, James Nidelet, M.D., performed the autopsies in these inquests, as he often did.

${ }^{154}$ Meyers and Berger Inquests. Other men killed each other in workplaces, too. For two cases of men who murdered coworkers on steamboats, see: William Horan Inquest, March 22, 1885, Case No. 1571, Folder 156, Box 41 (Missouri State Archives microfilm roll C31282), St. Louis City Office of the Coroner-Inquests 1845-1900, Missouri State Archives, Jefferson City, Missouri; John Walton Inquest, 
All three men made statements regarding the events and Koebel maintained that he acted in self-defense, a common argument that perpetrators made in homicide inquests. Meyer and Berger made statements to Dr. M.J. Epstein before they died and Koebel spoke to Coroner Nidelet as well as reporters. Both Meyer and Berger identified Charles Koebel as the man who stabbed them and Berger maintained his statement to the physician until he died. Koebel told the coroner and his jury that Meyer and Berger started the fight and threw the first punch. He pulled his knife only after the three of them were fighting. Koebel also told the press that he acted in self-defense and claimed that the two men had also cut him during the fight. When he learned that Meyer died from his stab wounds, Koebel told a Post-Dispatch reporter, ““'I'm sorry, but I couldn't help it...if they had let me alone I would have let them alone..." Koebel maintained his argument that he acted in self-defense after Berger passed several days later, although reporters commented that he was "nervous and anxious" when he learned of the second death. Koebel's anxiety likely stemmed from fear of additional murder charges as well as remorse over the stabbing. ${ }^{155}$

The coroner's jury did not believe that Koebel acted in self-defense and held him responsible for the deaths of both Meyer and Berger. The jury heard testimony that Koebel had been arguing with these two men before the deadly incident. Some who knew him claimed that he sometimes had a quick temper. But perhaps most damning were Koebel's actions. First, he stabbed both men so deeply that he punctured their organs and even pulled Meyer's lung and Berger's intestines partially out of their bodies.

\footnotetext{
June 20, 1876 Case No. 790, Folder 169, Box 9 (Missouri State Archives microfilm roll C31273), St. Louis City Office of the Coroner-Inquests 1845-1900, Missouri State Archives, Jefferson City, Missouri.

155 “It Is a Murder," St. Louis Post-Dispatch, February 1, 1884, 3; “The Second Victim” St. Louis Globe-Democrat, Thursday, February 7, 1884, 12.
} 
Second, Koebel immediately fled the scene of the crime. He also disposed of the murder weapon by throwing it over a bridge. When police found him at a friend's home the next day, however, he did not resist arrest. He told police about the stabbings and claimed that he only defended himself. Neither the coroner nor his jury believed him, however, and Coroner Nidelet obtained a warrant to charge Koebel with first-degree murder. ${ }^{156}$

As was fairly common in homicides, the presiding judge disagreed with the coroner and his jury, believing that Koebel did not intend to kill Meyer and Berger that day. Judge Noonan reduced the charges to third-degree manslaughter before convening a hearing in front of the Grand Jury. Noonan believed that Koebel's claim that he had acted in self-defense. The judge claimed that Koebel was provoked by Meyer and Berger, who approached him with the intent "to beat him up" and Koebel had good reason to believe that they would. If convicted, Koebel would have spent up to three years in the state penitentiary. ${ }^{157}$

Because he appeared to be a respectable family man, Koebel gained the sympathy of the St. Louis press. The fact that he died of bronchitis while awaiting his trial also garnered him sympathy. The Globe-Democrat wrote a brief story about his death and noted the crimes for which he was supposed to stand trial, but the Post-Dispatch wrote a sympathetic account. The reporter claimed that Koebel "was a young man of quiet manner and steady habits." After working hard at the machine shop, the reporter wrote, he then "trudged home to a widowed mother," for whom he provided the sole financial

156 “A Fatal Affray,” St. Louis Globe-Democrat, Thursday, January 31, 1884, 12; "Stabbed to Death," The Milwaukee Sentinel, Thursday, January 31, 1884, 2; "The Twelfth Street Tragedy," St. Louis Globe-Democrat, Friday, February 1, 1884, 10; "The Criminal Courts," St. Louis Globe-Democrat, Friday, February 8, 1884, 9.

157 “The Criminal Courts," St. Louis Globe-Democrat, Saturday, March 8, 1884, 12. 
support. After recounting the crime, the reporter concluded that he acted in self-defense and fled the scene because he was "seized with fear" and "unconsciously" disposed of the weapon. The reporter concluded that the cause of Koebel's death was not bronchitis, but, as his "more sympathetic neighbors" claimed, "a broken heart."158

One of the biggest perceived threats to manhood was having an affair with one's wife or lover and this prompted John Long to stab and kill John Fields. Unlike in cases in which men killed their wives and then themselves, however, there is no evidence of domestic violence in these cases, perhaps because the coroner did not look for any because men, not women, were the victims. Race, class, and reputation mattered, too, as evidenced by the murder of John Fields by John Long. Both men were about thirty years old, black, and worked as roustabouts on a steamboat. They had been friends and coworkers for about thirteen years, but had had conflicts before the stabbing, dating back a few months. The pair fought over one, and perhaps two, women. On the day that Long killed Fields, Long apparently became angry because Fields came to his house and spoke to his wife when he was not home. Evidently, Fields spent a lot of time with Milly Long when John Long was not home. ${ }^{159}$

The deadly fight began for two possible reasons - either because Long confirmed Fields' affair with his wife or because he learned that Fields was having an affair with the same woman that Long was also sleeping with, Barbara Fields. Regardless of what

158 “Criminal Court," St. Louis Post-Dispatch, May 4, 1885, 7 (first three quotes); "Multiple News Items," St. Louis Globe-Democrat, Tuesday, March 31, 1885, 8; "Criminal Court," St. Louis Post-Dispatch, May 4, 1885, 7; Meyers and Berger Inquests. A translator was present for the inquest because so many witnesses spoke German. Koebel was raised in a working-class household, apparent in the fact that many of his siblings and he worked in factories as teenagers. Some of his siblings did attend school, though. US Bureau of the Census, 1880, ancestry.com [accessed October 3, 2016].

159 John Fields Inquest, February 23, 1884 Case No. 741, Folder 99, Box 37 (Missouri State Archives microfilm roll C31281), St. Louis City Office of the Coroner-Inquests 1845-1900, Missouri State Archives, Jefferson City, Missouri. 
initiated the fight, it quickly turned violent and Long stabbed Fields, tossing the knife in a stove afterward. He did not flee, however, but turned himself in to police. John Long told the coroner the first version and that he stabbed Fields only after he hit him "so hard I seen stars. So I thought I had better look out for myself, because I know how all Steam boat men is." The police officer who responded to the scene told a different story, that Long had told him, "I am a square man, I give myself up. I don't allow no man monkeying with my wife." Regardless of what exactly prompted the fight, Coroner Nidelet's jury found that John Long was responsible for John Fields' death, rejecting his claim of self-defense. ${ }^{160}$

While the witnesses at the inquest had different opinions as to what caused the stabbing, St. Louis newspaper reporters agreed; it was because Fields had an affair with Long's wife. It was not uncommon for reporters to not take a side in accounts such as this, but the fact that reporters did not believe Fields' claim of self-defense is revealing. Fields was an African American roustabout on a steamboat-race and class positions that many in the white middle class associated with a propensity for violence. Unlike Josiah Colcord, whose murder-suicide was excused by the press and some of his former colleagues, or Charles Koebel, who supposedly died "of a broken heart," the press did not excuse John Long. Reporters did, however, claim that Long had been drinking gin before stabbing Fields, as they had with Josiah Colcord, but witness testimony did not

${ }^{160}$ Fields Inquest. James Nidelet performed the autopsy in this case as well. Coroner Nidelet believed that Long abused his wife, but she denied it (which is not surprising considering her husband was in the room). No other testimony indicates that he beat her, but considering he stabbed another man, it is certainly possible.

For another case of one man killing another over a fight over a woman, see: Stephen Hinchey Inquest, May 22, 1883 Case No. 125, Folder 124, Box 33 (Missouri State Archives microfilm roll C31280), St. Louis City Office of the Coroner-Inquests 1845-1900, Missouri State Archives, Jefferson City, Missouri. 
corroborate that claim (as it did not in the Colcord case). Perhaps alcohol use was a common explanation to help reporters and readers understand why someone would commit murder. Long spoke to a reporter for the Globe-Democrat and offered contradictory statements: that he acted in self-defense, but also that he did not know what he was doing. Reporters were neither critical of nor sympathetic to Long, but recounted the details of his quarrels with Fields and his statement. It is interesting that the press did not condemn him, either, though and perhaps indicates that his behavior wasn't entirely inexcusable. ${ }^{161}$

Regardless of Long's (contradictory) claims that he was defending himself, as in most homicide cases, Coroner Nidelet did not believe that Long acted in self-defense and issued a warrant for first-degree murder. As was fairly typical in homicides of all degrees, Long's case was continued several times before he was tried. He pled guilty to a lesser charge, that of second-degree manslaughter, and served five years in the state penitentiary. Fields and his family were not the only victims of Long's crime. Long could not support his own wife while he was in prison and she became destitute. A brief, sympathetic news article mentioned that she was requesting help, but the reporter also pointed out that her husband was serving time for manslaughter. ${ }^{162}$

161 "Criminal Matters," The Milwaukee Sentinel, Saturday, February 23, 1884, 2; "Concerning a Woman," St. Louis Globe-Democrat, Saturday, February 23, 1884, 12; "Criminal Courts," St. Louis GlobeDemocrat, Sunday, February 24, 1884, 13.

162 “The Criminal Courts," St. Louis Globe-Democrat, Tuesday, February 26, 1884, 9; "The Criminal Courts," St. Louis Globe-Democrat, March 8, 1884, 12; “The Criminal Courts," St. Louis GlobeDemocrat, April 12, 1884, 12; "Criminal Courts," St. Louis Globe-Democrat, Tuesday, November 18, 1884, 12; "Criminal Courts," St. Louis Globe-Democrat, Tuesday, November 25, 1884, 10; "Criminal Courts," St. Louis Globe-Democrat, Wednesday, November 26, 1884, 9; "Criminal Courts,” St. Louis Globe-Democrat, Tuesday, Friday, February 27, 1885, 12; St. Louis City Circuit Court, Criminal Court Record Book Volume, 25, 74; "Roll of the Destitute," St. Louis Globe-Democrat, Saturday, January 10, $1885,8$. 
Although men committed most homicides, women killed others, too, and often for the same reasons as men, including struggles over power, after longstanding conflicts, because of jealousy, and during the commission of other crimes. Only two women in this study committed homicides and both were African American women with criminal histories and bad reputations. Their crimes and punishments were similar to their male counterparts. Neither faced a sympathetic jury or press and, like black men, faced quick trials, strict punishments, and racist newspaper accounts of their crimes. Of thirteen inquests into homicides, only two women appear as perpetrators, with one of those cases being ruled as an accident. ${ }^{163}$ Searches of local newspapers revealed more so-called "murderesses," but only one additional inquest could be found. The low numbers of female murderers is not surprising because other historians have found similar trends. Jeffrey Adler points out that women (particularly native-born white women) were most likely to kill their children, particularly babies, in cases of infanticide. Their next mostlikely targets were their husbands and often received sympathy and light or no sentences in the late nineteenth century if they claimed that they were defending themselves against an abusive husband. Neither of the two women who committed homicides in this study fits these descriptions, and, in fact, had similar motives to the men in this study. Because they were not killing abusive husbands or lovers, or perhaps suffering from a madness that prompted them to kill their children, coroners, their juries, and the press showed no sympathy for these women. ${ }^{164}$

${ }^{163}$ Daniel Bergen Inquest, date, Case No. 1856, Folder 87, Box 20 (Missouri State Archives microfilm roll C31276), St. Louis City Office of the Coroner-Inquests 1845-1900, Missouri State Archives, Jefferson City, Missouri.

${ }^{164}$ Adler, Deepest in Dirt, 201, 204. Some inquests appear in the Coroner's Inquest database, but they are indexed incorrectly because I could not find them on the reels. Some murders appeared in the newspaper, but were not in the database. 
The deadly fight between Katie Quick and Amelia Keyes on February 25, 1895 was similar to that of Charles Koebel, Charles Meyer, and Albin Berger because the women had longstanding conflicts and were confined in close quarters at the Work House, where both served sentences for minor crimes. The immediate trigger for their last and deadly conflict was a hair ribbon, much like the wash bucket was for Koebel, Meyer, and Berger. The two African American women argued often during their time at the Work House. On the day that Quick assaulted Keyes, the two fought because Quick accused Keyes of stealing a ribbon for her hair. Not only was Keyes offended by the accusation, but Quick said she wanted to know "who the damn bitch was" who stole the ribbon. Keyes warned Quick not to call her names, and Quick replied, "I'm not calling you that, Mrs. Keyes; I don't want to have any trouble with you, but if the cap fits you you can wear it." Keyes then struck Quick and even clawed her face. Work House officials separated the women once they learned of the incident, but their fight did not end. The next morning Keyes threatened Quick through her cell door. Once out of her cell, Quick followed Keyes, grabbing a piece of brick that she saw in a corner. Quick then hit Keyes with the brick. Quick immediately reported herself to the Work House foreman and told him that she was "sorry" that she had struck Quick and hoped that she did not die from her injuries. She must have struck her hard, because Keyes struggled to speak after the assault and died of "congestion of the brain" about a week later. The forty-four-year-old left behind twenty-three children. ${ }^{165}$

165 Amelia Keys Inquest, March 7, 1885 Case No. 1540, Folder 125, Box 41 (Missouri State Archives microfilm roll C31282), St. Louis City Office of the Coroner-Inquests 1845-1900, Missouri State Archives, Jefferson City, Missouri. Quick was younger than Keyes: age 27, according to a news account: “A Fatal Blow," St. Louis Globe-Democrat, Sunday, March 8, 1885, 20. 
As many men did, Quick claimed that she acted in self-defense because Keyes had not only assaulted her, but threatened to kill her. Quick never denied throwing the brick, however, and witnesses confirmed Keyes' story of the attack. Witnesses agreed that the two women argued before the attack, that Quick called Keyes a bitch, and that the two women fought over a ribbon. The coroner's jury concluded that Quick did not act in self-defense and held and held her responsible for Keyes' death, which they ruled a homicide. $^{166}$

Because of their race and criminal records, newspaper reporters described both women as "hard character[s]," but they had been in the Work House for minor crimesQuick to work off a fine and Keyes for receiving stolen goods. Reporters wrote only a couple of brief articles about the murder, pointing out that both women were African American and residents of the segregated Work House. The reporters were not entirely without sympathy, however. A Globe-Democrat reporter tried to understand why the two women fought over a "bright colored ribbon" and explained that such an item was "always dear to the heart of the female African." The reporter did not mention the pair's frequent fights, however. Both reporters for the Post-Dispatch and the Globe-Democrat suggested that a tendency to kill ran in Quick's family, however, as both pointed out that her mother was in jail as an accessory to murder. While reporters sought some explanation for Quick's act, they did not excuse them, as they did in for some homicides

${ }^{166}$ A news account claims she acted in self-defense. Quick did not say this in the coroner's inquest, though. "A Fatal Blow," St. Louis Globe-Democrat, Sunday, March 8, 1885, 20. 
committed by white men. Still, they were more sympathetic to Quick than they were to black men who committed homicides. ${ }^{167}$

While Katie Quick was not demonized by the press or the witnesses in her case, another black woman, Sadie Hayes, was vilified because she had a reputation as a prostitute who had attempted murder in the past. Hayes also shot a respected police officer while brandishing a gun on the streets of St. Louis, unlike Quick, who killed another inmate of the Work House. On October 8, 1883, the twenty-seven-year-old was walking with a friend when she was harassed by a black man. She pulled her revolver, preparing to defend herself, she claimed. Others in the neighborhood saw Hayes brandishing the weapon and called to Sergeant Peletiah M. Jenks, who approached Hayes to arrest her. She turned around and fired her gun at him, hitting him in the head. He died that night from his injuries, leaving behind a wife and five children. ${ }^{168}$

The testimony in Hayes' case reveals that many people who knew her or saw the shooting believed that she was determined to shoot someone that day, perhaps because she was drunk. All eighteen witnesses told Coroner Nidelet and his jury that Jenks did nothing to provoke the shooting. One witness claimed that Hayes' friend encouraged her to shoot the officer. Hayes insisted that she acted in self-defense, thinking she was going to shoot the man who had threatened her, if the shot that she fired hit anyone. She also

167 “A Fatal Blow,” St. Louis Globe-Democrat, Sunday, March 8, 1885, 20; “Killed With a Brick: A Quarrel Between Women at the Work House Results Fatally," St. Louis Post-Dispatch, March 7, 1885, 4. Quick's stepfather committed the murder for which her mother was an alleged accessory.

168 Peletiah Jenks Inquest, October 9, 1883, Case No. 462, Folder 113, Box 35 (Missouri State Archives microfilm roll C31281), St. Louis City Office of the Coroner-Inquests 1845-1900, Missouri State Archives, Jefferson City, Missouri. She had attempted murder before when a woman had an affair with her husband. The judge in that case gave her a lenient sentence, probably because she was a woman, if she promised never to be violent again, a promise she did not keep. "Cases Before Cady," St. Louis Globe-Democrat, Friday, July 14, 1882, 10. 
claimed that she had been drinking quite a bit of beer that day, suggesting that she was inebriated and was not thinking rationally. The jury did not believe that Hayes was drunk or that the shooting was an accident. They rendered a verdict of homicide with no mention that she had been drinking. ${ }^{169}$

Although local newspapers devoted far more attention to Hayes than to her victim, they did not seek an explanation for the shooting. Several news accounts mentioned her alleged occupation as a prostitute and all mentioned her race, as if shooting a police officer was to be expected of a black woman. Reporters claimed that she had a "thirst for blood" that day. A Globe-Democrat reporter contrasted her with her victim, writing that, "Sergeant P.M. Jenks, one of the oldest and best known members of the police force, was shot down like a dog by a worthless colored Cyprian." She was so hated by residents of St. Louis that officials feared that she might be lynched. Someone even threw a rock at a police officer, injuring him, in an effort to strike Hayes when she left the inquest. ${ }^{170}$

Because Hayes had been openly brandishing her revolver the day of the shooting and because some witnesses claimed they heard her say she was determined to shoot someone, St. Louis officials charged her with first-degree murder. At the inquest, she said that she did not intend to shoot anyone and added that she had been drinking, but witnesses did not corroborate either claim. Her defense attorney chose a different strategy: a defense of insanity. He brought in relatives who testified that she suffered from epilepsy, evident by "fits" throughout her life. Medical experts testified that Hayes

169 Jenks Inquest.

${ }^{170}$ A Devilish Deed," St. Louis Globe-Democrat, Tuesday, October 9, 1883, n.p; Local Brevities," St. Louis Globe-Democrat, Thursday, October 11, 1883, 4. 
had both epilepsy and hysterical mania, both of which could cause sufferers to become "irresponsible" and harm themselves or others. Even without having any other disorders, epilepsy alone could have made Hayes "permanently insane," the physicians argued. The jury did not believe that Hayes was insane, however. After deliberating for only forty minutes, they convicted her of first-degree murder and sentenced her to death. She was not executed, however, because of her attorney's appeals, a stay of execution, and a new trial in which she was sentenced to ninety-nine years in the penitentiary. ${ }^{171}$

Hayes may have escaped the death penalty because she was a woman. She had previously faced charges for attempting to kill another woman who was having an affair with her husband, but a lenient judge did not sentence her as long as she promised not to assault or try to kill anyone again. Obviously, Hayes did not keep her promise and the next judge and jury were not lenient at all. While Judge Cady may have been sympathetic to her because she was a woman, by the time she was tried for killing Sergeant Jenks, her reputation as a rough woman seemed to be well-known. Newspaper reporters claimed that she had several husbands and beat them, evidenced by "the shape of lumps on their heads and razor slashes on their bodies." Yet she managed to continue to attract men, such as William Lacey, with whom she fell in love before and during her prison stay. The two corresponded while they both served time in the penitentiary, and she so beguiled him that he cut off his finger and sent it to her in her jail cell, according to the Globe-Democrat. While it is unknown how much truth there is to these accounts,

171 "The Criminal Courts," St. Louis Globe-Democrat, Wednesday, April 2, 1884, 11; "Criminal Courts," St. Louis Globe-Democrat, Thursday, April 3, 1884, 9; "The Criminal Courts," St. Louis GlobeDemocrat, Friday, April 4, 1884, 12; "Crimes and Casualties," The Galveston Daily News (Houston, Texas), Sunday, April 6, 1884, n.p; "Multiple News Items," The Cleveland Herald (Cleveland, Ohio), Thursday, June 5, 1884, 4; “Civil Courts," St. Louis Globe-Democrat, Thursday, November 27, 1884, 9; "Sadie Hays Relieved," St. Louis Globe-Democrat, Friday, January 8, 1886, 5. 
it is clear that Hayes would have been considered to be a violent woman, not only for openly carrying a revolver around town, but for arguing with others, cursing, and, of course, for killing and attempting to kill others. ${ }^{172}$

Hayes and Quick differed from many, mostly white, women who killed their husbands and/or children, according to the St. Louis press. St. Louis newspapers printed stories from across the country of women who poisoned their husbands, children, and other relatives. Some women killed multiple people and, like men, killed men and women alike out of jealousy_-lovers, former lovers, and women who had affairs with their lovers and husbands. The press gave some of them clever names, such as "The Veiled Murderess," which they did for some men who killed as well. Some women housekeepers killed their employers and their children. One woman committed suicide after killing another woman, but men were more likely to commit murder-suicides than were women. Unlike their coverage of men who killed, newspapers seldom discussed women who beat their husbands and then killed them, or women who killed each other at work. Women who received clever nicknames like "The Veiled Murderess" were white, middle-class or more affluent women, making them more respectable, and fascinating, killers than working-class black women like Katie Quick and Sadie Hayes. ${ }^{173}$

172 "Love in the Jail," St. Louis Globe-Democrat, Thursday, March 11, 1886, 12. Lacey said she asked for his ring and his finger, so he sent them to her. She reportedly fainted when opening the letter containing his bloody finger.

${ }^{173}$ Here are just a few newspaper accounts of women murderers: "Mrs. Robinson, the "Veiled Murderess,"” The Liberator (Boston, Massachusetts), Friday, July 6, 1855, n.p; "The Veiled Murderess," St. Louis Globe-Democrat, Sunday, June 6, 1875, 2; "Mrs. Stiepel was a Strange Woman," St. Louis PostDispatch, January 28, 1896, 7; “The Story of Maud Lewis' Life," St. Louis Post-Dispatch, July 26, 1895, 3; “A Child-Murderess," St. Louis Post-Dispatch, July 22, 1879, 2; "Murderess Murdered," St. Louis PostDispatch, March 29, 1895, 1; "Murderess, Mad Woman or Innocent?," St. Louis Post-Dispatch, March 4, 1882. 7; "The Devil's Day Book," St. Louis Post-Dispatch, October 25, 1878, 1; "A Woman Charged with Murder," St. Louis Globe-Democrat, Tuesday, August 23, 1887, 2; "Bereft of Reason," St. Louis GlobeDemocrat, Wednesday, November 10, 1886, 12; "Killed by Poisoned Soup," The Milwaukee Sentinel, Monday, August 2, 1886, 2; "The Belleville Tragedy," St. Louis Globe-Democrat, Tuesday, June 9, 1885 , 12; “"The O'Fallon Horror,” St. Louis Globe-Democrat, Saturday, August 30, 1884, 8. 
Although women murderers were unusual and garnered press attention, it was Frank Rande's murder of Officer John White that gained the most press attention out of all of the homicides explored in this chapter because he fit the stereotype of a desperado who fascinated the public. Rande's shooting of White was also an atypical homicide, though because both men and women tended to kill people they knew, not strangers. Frank Rande, also called "Desperado Rande," shot police officer John White on the morning of November 16, 1877, when White attempted to arrest him in Robert Wright's Pawn Shop in St. Louis because he was wanted for murder. Police had been expecting Rande to arrive in St. Louis to collect some belongings at the pawn shop for about ten days. When he arrived at the pawn shop, a staff member immediately went to notify a police officer. Rande was talking to Wright, the shop owner, about the receipt for his bag of belongings when Officer John White arrived. Violence ensued when White put a hand on Rande's shoulder and told him, "My friend, we want you." Rande refused to be arrested and pulled a gun on the officer. Officer White, Wright, and Wright's staff pulled guns, too. Several of these men fired shots during a ten-minute fight in the shop. Both Rande and Officer White were shot-Rande above the heart and White in the thigh. Although Rande suffered the more serious wound, he ultimately recovered. White did not, however, and developed gangrene in his leg. An amputation did not save him from 
dying from septicemia. White left behind a wife and daughter. Newspaper reporters wrote about White's bravery and the funds that St. Louis residents raised for his family, but like the other cases in this chapter, most focused on Desperado Rande and his violent activities rather than his victim. ${ }^{174}$

Because of Rande's notoriety and the fact that John White was a respected police officer, newspapers wrote about both of them long after the investigation into White's death had ended. Frank Rande represented the kind of outlaw manhood similar to that of Jesse James and while the press condemned him for his crimes, they simultaneously fueled his fame by writing numerous stories about him. Rande came to the attention of the residents of St. Louis when he shot Officer White, but by then he was on the run from officials in both Iowa and Illinois. Rande escaped from prison in Iowa where he was serving time for burglary and was then sent to a Michigan City prison. Sometime after he was released, he went to the small town of St. Elmo, Illinois, where he robbed a local farmer while he and his family were at church. The man and neighbors confronted Rande in a field, where he was attempting to hide, and he shot several of them, including a young boy. He fled to St. Louis, traveling with another man, and the two stole rides on freight trains and lived "as tramps." Rande had hoped to retrieve a bag with his belongings at the pawn shop and continue to flee authorities, but instead he began a shoot-out with police. ${ }^{175}$

${ }^{174}$ John White Inquest, November 19, 1877, Case No. 17, Folder 156, Box 12 (Missouri State Archives microfilm roll C31274), St. Louis City Office of the Coroner-Inquests 1845-1900, Missouri State Archives, Jefferson City, Missouri.

175 John White Inquest, November 19, 1877, Case No. 17, Folder 156, Box 12 (Missouri State Archives microfilm roll C31274), St. Louis City Office of the Coroner-Inquests 1845-1900, Missouri State Archives, Jefferson City, Missouri; "Frank Rande Suicides," Rocky Mountain News (Denver, Colorado), Saturday, March 8, 1884, n.p.; White Inquest; "The St. Elmo Murderer," Inter Ocean (Chicago, Illinois), November 19, 1877, 5. 
Rande claimed that he acted in self-defense, but neither witnesses nor the coroner believed him. Rande insisted to Coroner Hugo Auler that he was not sure that he had shot White at all, and, indeed, Auler had to interview several witnesses to determine who shot whom. Rande told the coroner that he shot himself in the leg (although he only had a wound in his chest) and that a staff member at the pawn shop must have shot Officer White. The coroner's jury did not believe him and held him accountable for John White's homicide. Rande tried to depict himself as a Robin Hood-type criminal, telling the press that he acted in self-defense whenever he killed anyone and he also claimed that he "'robbed the rich and gave to the poor." Another reporter claimed that Rande was expected to plead insanity for his defense, particularly because insanity ran in his family. This reporter did not believe that Rande was insane, evidently. Despite his numerous attempts to defend himself, Rande faced charges for the murders he committed in Illinois and was sentenced to life in prison in Joliet. ${ }^{176}$

Unlike Katie Quick, who killed another woman in the Work House, newspaper reporters believed that Frank Rande's upbringing could not possibly have been responsible for his life of crime because he came from a respected family in a good neighborhood. Newspapers reported on Rande's crimes once more seven years after he killed White because he died suddenly. After attacking a deputy warden at Joliet prison and being sent to solitary confinement, "Desperado Rande" hanged himself with his underwear. He was a sensationalist press topic once more. A Denver reporter claimed

\footnotetext{
176 "Rande-His Opinion of Himself," Inter Ocean (Chicago, Illinois), Monday, December 10, 1877, 3; "The Criminal Calendar," St. Louis Globe-Democrat, Monday, February 4, 1878, n.p; "The Bandit Tramp," St. Louis Globe-Democrat, Sunday, February 10, 1878, 10; "Rande's Sentence," Milwaukee Daily Sentinel, Monday, February 25, 1878, 2; "Desperate Deeds," Inter Ocean (Chicago, Illinois), Wednesday, December 12, 1877, n.p; "Frank Rande's Brain," Rocky Mountain News (Denver, Colorado), Sunday, March 23, 1884, 14. There are numerous news accounts of Rande, his numerous aliases, and his life before he committed these murders. He once worked as a schoolteacher.
} 
that scientists should study his brain to learn whether he was "a freak of nature in her most diabolical mood, or a lunatic," with the latter being the kinder option. The reporter claimed that Rande's monstrous nature could not be caused by his upbringing, since "he belonged to a respectable family, remote from those centers of population which breed habitual criminals." This reporter believed that Rande must have been insane or had some other genetic disorder that made him a killer because he understood his family and home to be good ones. Reporters did not consider most murderers to be insane and while this reporter's tone was not sympathetic, his insistence on an explanation for Rande's crimes was unusual. Only a few men received such explanations and all were white and respectable (or had respectable families), regardless of class. For other perpetrators of homicides, particularly African Americans, reporters seemed to believe that it was in their nature to kill—whether or not they came from "bad" families or neighborhoods. ${ }^{177}$

In contrast to Rande, local newspapers wrote sympathetic stories about his victim, John White, but nonetheless included updates about his killer in most articles. White struggled to survive the bullet wound to his thigh, but he developed gangrene and an amputation did not save him. The Globe-Democrat and White's fellow police officers raised funds to support his widow and daughter. The Post-Dispatch noted that Officer White was a valuable officer and good man, evidenced by the fact that people from “every grade of society” attended his funeral. ${ }^{178}$

177 “Frank Rande's Brain,” Rocky Mountain News (Denver, Colorado), Sunday, March 23, 1884, 14; "For Life or Death," The Cleveland Herald, Sunday, March 2, 1884, n.p;

"Frank Rande Suicides," Rocky Mountain News (Denver, Colorado), Saturday, March 8, 1884, n.p; "Frank Rande's Brain," Rocky Mountain News (Denver, Colorado), Sunday, March 23, 1884, 14; "Thirteen Lucky for Once," The Milwaukee Sentinel (Milwaukee, Wisconsin), Monday, March 24, 1884, 7.

178 "Laid to Rest," St. Louis Post Dispatch, November 20, 1877, 1. 
Despite more newspaper articles about Officer White than for most men and women who died from homicides, he was still overshadowed by his killer. ${ }^{179}$ Even more than a decade later, newspaper reporters wrote of Rande. In 1889, White's widow began to suffer from a mental illness of some kind. She struggled emotionally after White passed away. She used the money that the residents of St. Louis raised for to open her own grocery store to support herself, but the business venture failed. She remarried and had a son with her second husband, Patrick Rogan, but by 1889, the couple was so poor that they could not afford their rent and were evicted from their apartment. Financial struggles may have exacerbated already-existing mental health issues because in January of 1889 she was seen carrying a gun. She even fired a shot "during one of her bad spells" and was arrested, being placed in the very cell that once held Frank Rande. She also had some delusions, believing that her second and first husband were the same person. While reporting these details and White's expected stay in a St. Louis asylum, reporters added to the headline: "the Victim of Desperado Rande." Unlike Sadie Hayes, who also brandished a revolver around town and had relatives claim she was insane, people believed that White was suffering from mental illness, took pity on her, and sought treatment for her. ${ }^{180}$

179 White Inquest; "Last Edition...," St. Louis Post Dispatch, November 16, 1877, 1; "Police Officer John White...," St. Louis Globe-Democrat, Monday, November 19, 1877, 4; "Duty and Death," St. Louis Globe-Democrat, Monday, November 19, 1877, 8; "Rande's Phiz," St. Louis Post Dispatch, November 19, 1877, 1; "Laid to Rest," St. Louis Post Dispatch, November 20, 1877, 1; "Noble Charity," St. Louis Globe-Democrat, Tuesday, November 20, 1877, 4; "Asleep in Calvary,” St. Louis GlobeDemocrat, Wednesday, November 21, 1877, 4; "The Widow and Orphan," St. Louis Globe-Democrat, Thursday, November 22, 1877, 8.

180 "Sent to the Asylum," St. Louis Post-Dispatch, January 31, 1889, 5. 
The sensationalistic coverage of Frank Rande was typical in cases of homicides because the press and even friends, relatives, and literal witnesses to these homicides discussed the motives of the perpetrators of homicides than they did the lives of their victims. In part, this was because officials sought to determine the intentions of these men and women to determine what, if any charges they should face. But murder also fascinates the public and sensationalistic stories of these killers sold newspapers. Although witnesses, coroners, and reporters sought to understand why these men and women killed others, they sometimes missed crucial aspects of these cases, particularly in instances of domestic violence. Their assumptions about the ways in which respectable and disreputable men and women behaved made it difficult to recognize that an affluent man beat his wife or that African American men and women might suffer from insanity. Witness, coroners and their juries, and, especially, the press also, at times, tried to simplify these cases in terms of villains and victims, but in some cases, such as those of Quick and Keyes and Koebel, Berger, and Meyer, longstanding fights and threats blurred the lines between perpetrators and victims of homicides. One person became a killer, but after fights that could have made one of the victims perpetrators had events developed differently. Finally, there was a crucial difference between the ways in which black and white murderers were treated. White career criminals were "desperadoes" whose acts were simultaneously celebrated and depicted as evil, while black men and women were often treated as part of a dangerous "criminal class." Black men and women often faced harsher sentences and were tried more quickly than their white counterparts. And although some planned their murders, each committed their final, deadly acts in moments of passion or desperation. 


\section{Chapter Five}

"No one is to blame:" Accidental Deaths

Thirty-nine-year-old John Brennan died from burns and scalds after a boiler exploded at the Collier White Lead and Oil Company while working his shift as a foreman around 2:00 a.m. on the morning of June 5, 1876. The boiler pressure suddenly fell during the overnight shift and steam began to come from an unusual spot in the boiler about fifteen minutes before it exploded. Its pump also stopped working. John Brennan was in the boiler room when it exploded. The blast shook much of the neighborhood, ruined a large part of the building, and scattered debris for blocks. The explosion caused a fire in the building and several employees, including Brennan, were unable to escape. Even the company's fireman and acting engineer that night, Nicholas Degendorf, suffered internal injuries, burns, and bruises. City firemen rushed to the scene to extinguish the flames and rescue the men who worked there. ${ }^{181}$

Soon after the firefighters doused the flames, Coroner George G. Dudley, M.D., conducted a lengthy inquest to determine the cause of the explosion - the source of the company's sixth fire. Dudley interviewed fifteen witnesses, many of whom were engineers, to determine if any individual caused the explosion or if the Collier White Lead and Oil Company was to blame. A coroner's jury found that the company was not to blame, but an individual was: Nicholas Degendorf, the acting engineer during that shift. Witnesses who were coworkers of Brennan's told the coroner and his jury that Degendorf had been drinking before he showed up for work, and while Brennan and the

${ }^{181}$ John Brennan Inquest, June 6 and 7, 1876, Case No. 113, Folder 117, Box 8 (Missouri State Archives microfilm roll C31273), St. Louis City Office of the Coroner-Inquests 1845-1900, Missouri State Archives, Jefferson City, Missouri. Hereafter it will be referred to as "Brennan Inquest." 
engineer from the previous shift, John Kauffman, believed he was "able to attend his duties," other coworkers disagreed. The jury also disagreed because of Degendorf's intoxication. He also allegedly made a damning statement about the boiler when warned that it was malfunctioning: "Let her blow to hell." The coroner's jury held Degendorf responsible for the explosion and claimed he was guilty of "negligence"—but not criminal negligence, and certainly not homicide. St. Louis officials never charged Degendorf with any crime. Neither the jury nor the press held Collier White Lead and Oil Company responsible for Brennan's death, even though they hired Degendorf and their company had had five previous fires. As was typical in instances of accidental deaths in the workplace, the jury did not blame the company for negligence, but they did make an uncommon decision by blaming on a single person-a supervisor. ${ }^{182}$

John Brennan's death is just one of thirty-four accidental deaths examined in this study and the only one in which a jury held someone else accountable. More often, no one was held responsible at all, although in some cases employers, the deceased, or others (such as neighbors who started fires accidentally) took actions that caused these accidents. Accidental deaths occurred when men and women died in unexpected circumstances: falls, drownings, vehicle accidents, and accidents when equipment at work malfunctioned. No one intentionally killed these men and women, nor did they

182 Special thanks to Mike Everman at the Missouri State Archives for searching criminal and other record books to determine that Degendorf never faced any charges.

Brennan Inquest; "Terrific Explosion," St. Louis Globe-Democrat, Monday, June 5, 1876, 5; “Casualties," Milwaukee Daily Sentinel, Tuesday, June 6, 1876, 5; Burst Boilers," St. Louis GlobeDemocrat, Wednesday, June 7, 1876, 8; "Want of Water," St. Louis Globe-Democrat, Thursday, June 8, 1876, 3; "The Recent Explosion-Progress of the Inquest," St. Louis Post-Dispatch, June 7, 1876, 4; "Blown Up.: Terrible Explosion at the Collier White Lead Works," St. Louis Post-Dispatch, June 5, 1876, 4. 
mean to take their own lives. ${ }^{183}$ Most often, coroners, their juries, and witnesses

concluded that no one, particularly not company owners, were to blame for accidents that took the lives of between one and several people. Coroners, usually alone, but sometimes with juries, called witnesses and sought to recount every detail of the events that led to the accidents to determine what happened and if anyone caused the accident, meaning, if it was potentially a homicide, or, in some cases, a suicide. Coroners were particularly thorough in cases of accidents that took place when the deceased was at work or was struck by a vehicle because they had to determine if the deceased, an employer, or another person was negligent and caused the accident. Despite Missouri laws that made it necessary for coroners to potentially assign blame in accidental deaths, there were few laws that held individuals or companies responsible for deadly negligence or dangerous workplaces. In late-nineteenth-century St. Louis, no workers' compensation laws existed, life insurance was rare, and few laws regulated workplaces, making it nearly impossible for coroners to hold others accountable for the accidental deaths that they investigated, even if others contributed to or caused those deaths. ${ }^{184}$

While the coroner sought to determine if an employer was responsible for deaths caused by accidents, their verdicts almost never held employers accountable and neither did their coroners' juries or newspapers. Most people believed that no one was

\footnotetext{
${ }^{183}$ Historian Judith Green defines accidents as an "unmotivated event" in which a "victim or other 'agency" was not to blame. Accidents should also be "unpredictable as a unique event" and could not have been "foreseen." In practice, Green argues, accidents were not classified so narrowly and someone was at least partially to blame for these events. Judith Green, "Accidents: The Remnants of a Modern Classificatory System," in Accidents in History: Injuries Fatalities and Social Relations, edited by Roger Cooter and Bill Luckin (Amsterdam: Editions Rodopi B.V., 1997): 35-58. Quotes from page 36.

${ }^{184}$ Roger Lane also found this in his study of suicides, homicides, and accidents in Philadelphia. Coroners' inquests were particularly important when workers and pedestrians died in railroad accidents, he claims. Roger Lane, Roger Lane, Violent Death in the City: Suicide, Accident \& Murder in 19 ${ }^{\text {th }}$ Century Philadelphia. Cambridge, Massachusetts: Harvard University Press, 1979, 37-39.
} 
responsible for these tragic events, even in cases when they could have been prevented. In some cases, residents of St. Louis believed that the victims brought their deaths upon themselves. Witnesses, including people who saw these men and women die, recounted the facts in as much detail as possible and sometimes speculated as to the cause of the accident. In some cases, they had different accounts of what happened — such as the speed of a striking vehicle. Their perspectives could vary by their interests in a case, such as train engineers who testified that trains were moving more slowly than bystanders claimed. Newspapers provided more coverage for large accidents in public places than for accidents at home and/or those that killed one person. Newspaper reporters recounted the gruesome details of the accidents, but seemed to be more concerned with the insurance of damaged buildings and the estimated cost of the damages than aiding the victims and their families. Newspapers seldom mentioned the liability of building owners in cases of explosions and fires, although some laws existed that held them liable. Witnesses and the press often blamed the victims of accidents for their deaths, especially at work.

Victims of accidents differ from those who died from suicide, homicide, alcoholrelated deaths, or those who died from abortions in several ways. First, they tended to be older — many between ages forty and fifty—and German immigrants are overrepresented. Many worked as laborers and, like the other men and women in this study, were workingclass. Unlike many of the other men and women in this study, however, most were integrated into, rather than isolated from, their families and communities. In a few cases, this closeness to family members may have prompted the coroners to issue verdicts of accidental death rather than death by suicide because of the testimony of these relatives. 
Another difference is that most of these men and women were respected members of their communities, regardless of race and class. Many of these men and women also died in public, rather than at home, although men and women with disabilities were more likely to die at home than those who were able-bodied. Gender differences are notable with regard to location of death: men often died at work, while women had accidents while running errands in public, but more often died at home. A final difference is that although several accidents may have been caused, in part, by alcohol use, the coroner did not add references to alcohol in his verdict, distinguishing these cases from those discussed in Chapter Two.

The kinds of accidents that are considered vary widely. Thirty-four men and women died from falls, drownings, burns, elevator malfunctions, and train and other vehicular accidents. Of these thirty-four deaths, only two cases featured evidence of relationship conflicts, including domestic violence - a key difference from other causes of death explored in earlier chapters. Four cases went to juries and of those four, they only rendered a verdict of criminal negligence in one of them. Because the coroners investigated these cases to determine if anyone was accountable for causing these accidents, the chapter is organized by the degrees of responsibility on the part of others. First, suspicious cases (potential suicides and one homicide) are examined. Next, cases in which other people were potentially responsible are explored. Finally, cases in which the deceased or no one at all was responsible are discussed, including those that overlap with natural deaths and illnesses.

The fact that these men and women often lived with their family members is important not only because they shaped the coroner's investigations, but also because 
newspapers depicted their deaths as more tragic because they left relatives behind.

Coroners interviewed relatives even when they were not present when their loved ones died and coroners placed their testimony first in the inquest record, whether or not they were first interviewed, indicating that coroners considered the statements of relatives to be most important. Newspapers noted when victims had spouses and children whom they left behind, even in short articles. Reporters also mentioned if the victims were particularly well-respected. If a family struggled after a loved one died in an accident, reporters sometimes mentioned that too, and suggested that they needed charity. In contrast to the wives of murdered police officers discussed in Chapter Four, no newspapers or coworkers appeared to have raised money for the families of men and women who died from accidents, even when they occurred in their workplaces. Although civil lawsuits for damages were possible, families of accident victims seldom went this route, probably because they did not expect to be successful and perhaps because few could afford attorneys to do so. ${ }^{185}$

Coroners did not find all deaths easy to rule as accidents and, in some cases, they believed the deaths of men and women to have resulted from suicide, but had the testimony of friends, relatives, or other witnesses that prompted them to render verdicts of accidental death. For instance, Coroner Hugo Auler and Deputy Coroner Frank R. O’Neil could not determine whether twenty-two-year-old Mary Harris died from accidentally or intentionally setting herself on fire with a coal lamp on the night of June

${ }^{185}$ Donald W. Rogers argues that before some statewide reforms in the 1910s, employees were understood to engage in contracts with their employers and knowingly took on workplace risks. While employers were expected to exercise "due care" and provide safe environments, few laws and policies forced them to and courts seldom favored employees over employers. Donald W. Rogers, Making Capitalism Safe: Work Safety and Health Regulation in America, 1880-1940 (Urbana: University of Illinois Press, 2009, 12-14. 
17, 1880. Mary, a young African American woman who evidently had an abusive husband, spilled burning coal oil lamp onto her dress, setting herself on fire. She quickly extinguished the flames by rolling in blankets and was hospitalized soon after. At the City Hospital, she told a doctor and a nurse that she burned herself accidentally while using the coal lamp to light a fire in the stove to prepare her husband's supper. Her dress hit the lamp, causing her clothing to catch fire, she said. Although the doctors and nurses were treating her for the burns, Harris knew that she was going to die because she asked her mother to care for her daughter, Ida Jeffrides, and left instructions to give some of her jewelry to friends and family members. ${ }^{186}$

Although Mary Harris told the doctor and nurse that the fire was accidental, the investigating coroners had reason to doubt her story, yet they did not investigate as thoroughly as they could have. When interviewing witnesses, a neighbor, Harriet Valley, who shared a yard with Harris, told the investigators that Harris had set herself on fire to commit suicide. Harris worried that her husband would beat her "to death" because she had an affair with another man. To avoid the beating, Harris decided to take her own life before he could do so. She apparently changed her mind, though, and put out the flames soon after setting herself alight. Valley also testified that Harris asked her to care for her young daughter, which is perhaps part of the reason why the coroners were not sure about the truth of her testimony. Harris asked her mother, not her neighbor nor her husband, to care for her daughter after she died. She made these instructions while she was

${ }^{186}$ Mary Harris Inquest, June 18, 1880, Case No. 2087, Folder 38, Box 22 (Missouri State Archives microfilm roll C31276), St. Louis City Office of the Coroner-Inquests 1845-1900, Missouri State Archives, Jefferson City, Missouri; "Was it Suicide?," St Louis Globe-Democrat, Saturday, June 19, 1880, 8; "The Coroner," St. Louis Globe-Democrat, Sunday, June 20, 1880, 4. 
hospitalized, not before, giving no clues as to whether she intended to kill herself. A reporter for the Globe-Democrat seemed fairly certain that Mary took her own life in the article, "Was it Suicide?." The reporter recounted the inquest material, much of it verbatim, and seemed to believe that the coroners would render a verdict of suicide. Instead, Auler and O'Neil rendered an ambiguous verdict, being unable to determine if Mary Harris told the truth on her deathbed or if her neighbor's account was the accurate one. They did not interview Mary's mother or husband to determine her state of mind before the fire, which could have created a more solid verdict. Coroners almost always interviewed relatives in cases of suicides and accidents, so it would have made sense for them to do so in a case in which they were unsure of the verdict. Perhaps they did not because she was a poor black woman. ${ }^{187}$

Coroners did not only render an uncertain verdict in Mary Harris' case, but in other instances of suspected suicides as well. Deputy Coroner William Renick put the verdict of accident in quotes in the death of Mary Scott. His ruling indicated that he did not believe the testimony of the witness whom he interviewed, but had no other evidence to render a different verdict. Renick ruled that twenty-three-year-old Mary Scott died from "the effects of being burned by fire, the result of an 'accident"" after the African American housemaid died on January 26, 1883. Like Mary Harris, Mary Scott was young, black, and had a friend or relative to testify before the coroner. Unlike in the Harris investigation, however, Renick only interviewed one witness: Mary Scott's

\footnotetext{
${ }^{187}$ Mary Harris Inquest, June 18, 1880, Case No. 2087, Folder 38, Box 22 (Missouri State Archives microfilm roll C31276), St. Louis City Office of the Coroner-Inquests 1845-1900, Missouri State Archives, Jefferson City, Missouri; "Was it Suicide?," St Louis Globe-Democrat, Saturday, June 19, 1880, 8; “The Coroner,” St. Louis Globe-Democrat, Sunday, June 20, 1880, 4.
} 
mother, Hannah Smithers. Smithers testified that her daughter had had her back to a grate when her clothing accidentally caught fire. Although Drs. McPhelen and Chopin arrived soon after and treated her burns, Scott died the next day with her mother at her side. Her mother said "I blame no one for her death" and "I simply regard it as an accident." Deputy Coroner Renick's verdict in quotes suggests that he believed otherwise, but he did not interview any other witnesses, such as her employer or friends, so why he rendered the verdict is unknown. Other witnesses could have testified to Scott's recent behavior and moods - whether she had been despondent recently, perhaps, or had threatened to commit suicide. Perhaps Renick doubted Smither's testimony because she was the deceased's mother and he believed she was trying to cover up a suicide. Newspaper articles do not offer any additional evidence in the case because they did not report on Scott's death at all, as was common with when men and women died alone at home. Regardless of the reason, Renick had no evidence that Mary Scott's death was anything other than an accident and rendered the verdict as such, albeit in quotes. ${ }^{188}$

It was not only young, black women who received verdicts in which coroners were suspicious that the deceased may have died by suicide. Coroner Sylvester Nidelet rendered a verdict of a "supposed accident" in the death of twenty-four-year-old Timothy O-Keefe, an Irish immigrant. In this case, the coroner may have been suspicious that hospital staff were trying to protect themselves from potential liability for a patient who died in their care. O'Keefe had been in the Mullanphy Hospital for nearly two weeks when he either fell or, more likely, jumped from a third-story window on October 28,

${ }^{188}$ Mary Scott Inquest, January 27, 1883, Case No. 1331, Folder 59, Box 32 (Missouri State Archives microfilm roll C31280), St. Louis City Office of the Coroner-Inquests 1845-1900, Missouri State Archives, Jefferson City, Missouri. 
1884. The hospital admitted him for typho-malarial fever almost two weeks earlier, but O'Keefe believed that he would not recover from his illness. Although he was ill, the hospital staff and his visitors, including a priest, testified that he was never irrational or delirious, and that is why he was not restricted to a floor with barred windows. He was, however, despondent, according to his regular visitors, although the hospital staff disagreed. ${ }^{189}$

On the day of his death, a couple of young boys were on the floor and saw O'Keefe hanging out of a window when he let go of the sill and fell about forty feet, killing him. He had evidently climbed out of a window in the water closet and fallen to his death. Considering he was not delirious and he fell from a window in an area which was not visible from the nurse who walked the floor regularly, he likely committed suicide. Doctors responded immediately, but could not save him. O'Keefe had several people who knew him well and regular visitors - including a brother who came to see him daily and a priest who visited him three times a day. Coroner Nidelet interviewed four witnesses, all of whom worked at the hospital to determine what happened and O'Keefe's state of mind before he died. Hospital staff assured the coroner that they believed that O'Keefe was safe and that they would have restricted him to a floor with barred windows if he had been delirious at all. He did not interview his brother, though, which may have helped him decide whether the death was an accident or suicide, although two witnesses stated he was "despondent." Coroner Nidelet rendered a verdict that O'Keefe died "from compression of the brain" from a "supposed accident."

189 Timothy O'Keefe Inquest, October 28, 1884, Case No. 1293, Folder 94, Box 40 (Missouri State Archives microfilm roll C31282 and C31308), St. Louis City Office of the Coroner-Inquests 18451900, Missouri State Archives, Jefferson City, Missouri. 
Newspapers did not report on his death at all, likely because he died alone, even though he died in a public place. ${ }^{190}$

In contrast to men and women who died alone, perhaps by suicide, those who died in accidents in their workplaces garnered a lot of press attention and lengthy coroner's inquests. Despite this increased attention and the fact that they died at work, coroners, their juries, and the press almost never blamed potentially negligent employers and coworkers for these deaths. In the late nineteenth century, the law and most Americans believed that workers took on certain risks when they chose to work in a given profession. While employers were expected to provide safe equipment and competent management, laws seldom mandated this specifically. Workers were supposed to monitor their own behavior as well as that of their coworkers to maintain safety in the workplace. Many states did not have any workplace safety laws until the 1910s. As discussed in the opening story, the verdict in the death of John Brennan that found a coworker (and supervisor) to be negligent, is a notable exception to this trend. Although the coroner's jury held a supervisor responsible for Brennan's death, but they still did not hold the Collier White Lead and Oil Company accountable, which was typical in workplace accidents. The supervisor also faced no criminal or civil charges or suits for his negligence. ${ }^{191}$

The coroner's jury found Nicholas Degendorf, fireman and acting engineer, negligent and responsible for the boiler explosion at the Collier White Lead and Oil Company on the night of June 5, 1876, but mentioned nothing about his employer, despite some evidence that indicated that the company was to blame. Coroner George

\footnotetext{
${ }^{190}$ O'Keefe Inquest.

${ }^{191}$ O’Keefe Inquest; Rogers, Making Capitalism Safe, 11-13.
} 
Dudley interviewed fifteen witnesses in his investigation into Brennan's death—a large number. Dudley interviewed seven engineers to determine what, exactly, caused the boiler explosion, and each gave their expert opinions. The engineers disagreed as to the cause, however. Three engineers testified that the boiler did not have enough water in it at the time of the explosion and this is what caused the deadly accident. Four engineers claimed that a recent hydrostatic test strained the boiler and led to the explosion, many arguing that thin material in some areas contributed to the blast. Of course, if the acting engineer had been more attentive - and sober - the accident may not have occurred, regardless of the condition of the boiler, and the coroner's jury took this into account. The jury concluded that it was Nicholas Degendorf's negligence as well as too little water in the boiler that caused the accident. Although four engineers claimed it was the hydrostatic test and three claimed it was too little water that caused the explosion, the jury believed that the lack of water was to blame. ${ }^{192}$

The jury's verdict placed blame on individuals rather than the company. First, the jury believed witnesses who testified that Degendorf had been drinking before he came to work and that he remarked about the boiler, "let her go to hell" or "blow to hell." Second, although Degendorf relieved John Kauffman as foreman and Kauffman determined that Degendorf was not too inebriated to perform his duties, the jury held only Degendorf, not Kauffman, accountable for the explosion. The jury also believed that too little water, not a recent test or thin material, caused the explosion, another factor

192 Brennan Inquest. According to Missouri statutes in the late nineteenth century, an engineer had to manage boilers, which is probably why the coroner interviewed so many of them to determine the cause of the explosion. John A. Hockaday, Thomas H. Parrish, et. al, eds. Revised Statutes of the State of Missouri, Volume I. Jefferson City: Carter and Regan, State Printers and Binders, 1879, 1298; David R. Francis, Stephen H. Claycomb, Joseph J. Russell, eds. Revised Statutes of the State of Missouri, Volume I. Jefferson City: Tribune Printing Company, State Printers and Binders, 1889, 1714. 
that was the responsibility of a careless employee and not the company. Finally, the jury did not hear testimony about the previous five fires that occurred at the Collier White Lead and Oil Company and may not have known about them, another reason they did not hold the company responsible. ${ }^{193}$

Reporters for the Globe-Democrat and Post-Dispatch agreed with the coroner's jury. The newspapers wrote several accounts about the explosion, fire, and inquest. The Globe-Democrat noted that the "immense establishment has burned down half a dozen times," named the people who were injured (including Brennan), explained the details of the blast, and concluded by estimating the financial amount of damages as well as the company's insurance. Despite the company's multiple fires, the reporter did not place blame on the company, perhaps because they did not believe blame rested with the company. ${ }^{194}$ The Globe-Democrat, Milwaukee Daily Sentinel, and Post-Dispatch wrote about the injured men, Brennan's death, and the coroner's inquest, but none blamed the company. The Post-Dispatch concluded its last article by noting that photographs were taken of the ruins so that other companies could insure their own businesses and equipment appropriately. No reporters wrote about whether John Brennan had life

${ }^{193}$ Brennan Inquest; “Terrific Explosion,” St. Louis Globe-Democrat, Monday, June 5, 1876, 5.

194 “Terrific Explosion,” St. Louis Globe-Democrat, Monday, June 5, 1876, 5. Some companies intentionally set fires to collect insurance money, as the owners of the Triangle Shirtwaist Factory in New York did, but there is no evidence to suggest that this was the case with Collier White Lead and Oil Company. There was a controversy in 1881 regarding the Fire Department, however, but concluded that they were not to blame for not putting out a fire at the company quickly enough. Despite the company's numerous fires, there were few newspaper articles about them and, evidently, no suspicion of negligence or malice. "Investigating.: The Fire Department and the Management of the Collier Fire," St. Louis PostDispatch, October 17, 1881, 4.

"Not Guilty Enough." The Mayor's Qualified Decision in Regard to the Collier Fire," St. Louis Post-Dispatch, October 22, 1881, 4; David Von Drehle, Triangle: The Fire that Changed America (New York: Grove Press, 2003): 160-164. 
insurance, even though he was fairly young at age thirty-nine and had a wife to provide for. ${ }^{195}$

Unlike in the death investigation of John Brennan, in most cases of accidental deaths that occurred in the workplace, the coroner or his jury held no individual or company responsible. Both John Leich and Henry Wiese died from burns that occurred while tarring a filter at the Belcher Sugar Refinery on the morning of December 3, 1878, but Coroner Hugo Auler held no one responsible for the accident. The two men, ages thirty-one and forty-nine, respectively, and both German immigrants, tarred the filter by lamp light, as they had done nineteen times before. A coworker, James Asbury, heard someone shout and rushed to the filter where he saw "that the whole interior...was in a blaze." He and his coworkers quickly shut off the vent, but not before Leich and Wiese suffered deadly burns. Asbury had never heard of a similar accident occurring before, he testified, nor could he imagine anyone smoking in that area, not only because it was prohibited, but also because it was dangerous. Neither of the men smoked anyway, he said. Asbury also stated that workers filled their lamps with lard, not coal, oil, evidently because it was less dangerous if spilled. Asbury offered his own belief about how the accident occurred: "that the lamp broke; how or under what conditions I could not state." Herman Munsberg concurred with Asbury and added that the men who worked at the refinery always tarred the filter in the same manner. Leich and Wiese had tarred similar filters before the day they died, so a lack of experience or a different filter or technique

195 Brennan Inquest; “Terrific Explosion,” St. Louis Globe-Democrat, Monday, June 5, 1876, 5; “Casualties," Milwaukee Daily Sentinel, Tuesday, June 6, 1876, 5; "Burst Boilers," St. Louis GlobeDemocrat, Wednesday, June 7, 1876, 8; "Want of Water," St. Louis Globe-Democrat, Thursday, June 8, 1876, 3; "The Recent Explosion-Progress of the Inquest," St. Louis Post-Dispatch, June 7, 1876, 4; "Blown Up.: Terrible Explosion at the Collier White Lead Works," St. Louis Post-Dispatch, June 5, 1876, 4. 
was not to blame. After interviewing these men, Coroner Auler rendered a verdict of an accident, "from the effect of Burns."196

Newspaper reporters focused on the fact that both Leich and Wiese had families as well as the gruesome nature of their deaths in their lengthy and sympathetic articles. A Globe-Democrat reporter wrote that the two men were "literally roasted alive" in an "accident." The reporter explained to readers where the men were working, how the tar was positioned, and how witnesses believed a broken lamp set the tar — and the menablaze. The reporter also pointed out that both men had good characters and left behind families, particularly Wiese. Leich left behind a wife, while Wiese, an "industrious, sober citizen," left behind four children as well as a wife. The Milwaukee Daily Sentinel even mentioned that Leich and Wiese were "both men of family" in its brief account. Despite their sympathy for the men, no newspaper suggested raising funds for the families of these men, whether they had life insurance, or if the company would provide for them somehow, but they also did not mention the company's financial loss, either. ${ }^{197}$

Coroners and their juries did not hold companies accountable when elevator malfunctions killed men at work, either. In fact, some of the witnesses and the investigating coroners blamed the passengers for elevator accidents. Thirty-eight-year-

196 John Leich Inquest, December 3, 1878, Case No. 1101, Folder 247, Box 15 (Missouri State Archives microfilm roll C31274), St. Louis City Office of the Coroner-Inquests 1845-1900, Missouri State Archives, Jefferson City, Missouri; Henry Wiese Inquest, December 3, 1878, Case No. 1100, Folder 246, Box 15 (Missouri State Archives microfilm roll C31274), St. Louis City Office of the CoronerInquests 1845-1900, Missouri State Archives, Jefferson City, Missouri.

A similar inquest is that of Hugh Hogan. An old break in a cog wheel may have caused molten steel to spill onto Hogan, killing him, but neither another employee nor the company were held responsible. Hugh Hogan Inquest, November 4, 1881, Case No. 519, Folder 120, Box 27 (Missouri State Archives microfilm roll C31278), St. Louis City Office of the Coroner-Inquests 1845-1900, Missouri State Archives, Jefferson City, Missouri.

197 "Tar and Flames," St. Louis Globe-Democrat, Wednesday, December 4, 1878, 4; "Roasted and Ground," Milwaukee Daily Sentinel, Wednesday, December 4, 1878, n.p. 
old James Murphy was one such victim who was killed when an elevator fell from the fourth floor to the cellar of the wholesale firm of Gregory \& Stag. Murphy and four other people used the elevator in the early afternoon of May 18, 1875, not knowing that a crucial piece was missing: a stop-motion slide. The men boarded the elevator knowing that it had recently been repaired and that the slide had been replaced, but did not realize that Edward Jones, the repairman, was not finished with his work. Jones had been working on the elevator and had left to get a tool when Murphy and the other men used the elevator. Edward Larkin and Henry Eberle, also passengers, discussed whether or not the elevator was safe with the new guides and concluded that the elevator would, indeed, be able to stop. The men were wrong, however, because of the missing slide. They could stop the elevator manually, but did not think of this until it was too late. Edward Larkin survived the crash because he jumped, grabbed a rope, and slid down the rope to the first floor, where he called for help. James Murphy was not as fortunate. He fell with the elevator to the cellar and died from a skull fracture. Coroner George F. Dudley primarily blamed the passengers in his verdict: noting that the elevator was "incomplete in not having a Stop-motion-slide... and the neglect of the persons on the Elevator to take hold of the water-valve-rope and raise it." The coroner did not name the repairman, nor did he blame the company for failing to warn potential passengers of the danger. ${ }^{198}$

Newspaper reporters shared the details of the accident as well as the names, conditions, age, ethnicities, and families of each of the injured or deceased men. The Post-Dispatch did not blame anyone for the accident, but pointed out that the missing

\footnotetext{
${ }^{198}$ Missouri statutes existed for hotel and apartment building safety, but not for elevators in 1875 . James Murphy Inquest, May 19, 1875, Case No. 253, Folder 153, Box 6 (Missouri State Archives microfilm roll C31272), St. Louis City Office of the Coroner-Inquests 1845-1900, Missouri State Archives, Jefferson City, Missouri.
} 
slide caused it. The reporter listed each of the injured men, who were all taken to their homes and treated by physicians, except for Murphy, who died immediately. The reporter also praised Edward Larkin in two articles for thinking to grab the rope and save himself. Two of the other men received serious, perhaps life-threatening injuries. The reporter did not mention previous accidents at this or other firms, nor place any blame for the elevator crash, unlike the coroner, who claimed that the other passengers should have thought to use the emergency method to stop the elevator. ${ }^{199}$

Blaming the victims of accidents was not uncommon. Coroner John N. Frank and Deputy Coroner H. Praedicaw blamed Henry Diekhoener for his deadly elevator accident at work, as did his supervisor and newspaper reporters. Diekhoener was pulling up lead pigs at the St. Louis Shot Tower Company where he worked on the afternoon of July 21, 1881 when he died. The pigs would go into the tower where they would be melted and made into bullets. The elevator made three stops, as usual, but suddenly came crashing down. The sudden fall crushed Diekhoener's head, killing him. His supervisor, Orville Rule, testified that Diekhoener had failed to follow instructions by overloading the elevator with more weight than he should have. A coworker, Julius Gastrow, pointed out that the elevator did not work properly, however, telling the investigators that "What's the matter, she runs hard." He also observed that the elevator had been working the previous night and morning, though. The testimony of these witnesses suggests that it was both employee carelessness and faulty equipment that caused the deadly crash. ${ }^{200}$

${ }^{199}$ Murphy Inquest; "By the Fall of an Elevator...," Boston Daily Advertiser, Wednesday, May 19, 1875, n.p; "Very Latest.: 4 P.M. Shocking Calamity," St. Louis Post Dispatch, May 18, 1875, 1; "The Elevator Accident," St. Louis Post Dispatch, May 19, 1875, 1.

${ }^{200}$ Henry Diekhoener Inquest, July 21, 1881, Case No. 272, Folder 73, Box 26 (Missouri State Archives microfilm roll C31278), St. Louis City Office of the Coroner-Inquests 1845-1900, Missouri State Archives, Jefferson City, Missouri. 
Unlike in other cases, newspaper accounts did not focus on Diekhoener's position as a family man, but the coroners' inquest did. Coroners Frank and Praedicaw interviewed Diekhoener's wife and put her testimony first in their record. Maria Diekhoener stated that her husband "left a wife and 5 children" and was "in good health" when he left for work that morning. Post-Dispatch and Globe-Democrat reporters did not mention Diekhoener's family in their articles, but did mention that he carried two more lead pigs than he should have on the elevator. While the Globe-Democrat concluded that Coroner Frank would "inquire into the construction of the elevator with a view to properly locating the blame for this horror," the coroners concluded that the tragedy was an accident. They ruled that Diekhoener died "by the accidental fall of an overloaded elevator," not mentioning the fact that sometimes the elevator did not work properly, nor blaming the operator who tried to stop the fall. ${ }^{201}$

Sometimes, both employees and guests died in accidents that occurred in workplaces, such as the Planter House hotel fire on January 14, 1883. Carlos Rebori and Dennis Reponti were two employees of the nationally-renowned hotel who died in the fire that occurred between 3:30 and 4:00 that morning. Coroner Sylvester Nidelet investigated their deaths and concluded that both died "from the effects of being burned by fire (accident)." Nidelet sought to determine how the fire started, but despite interviewing seven witnesses, he never learned where the fire began, much less how. Rebori and Reponti both worked in the hotel's kitchen and also lived at the Planters House, but their deaths differed. Rebori, a thirty-eight-to-forty-year-old Italian immigrant, nearly escaped with others that night. Dotta Jissue and another person met

201 "Broken Bones," St. Louis Globe-Democrat, July 22, 1881, 3; Diekhoener Inquest; “Local Brevities," St. Louis Post-Dispatch, July 22, 1881, 3. 
Rebori when they were trying to escape the fire, but when they turned back from the smoky kitchen, Rebori kept going. They discovered his remains once the fire was put out. Rebori also had a brother in St. Louis who testified before the coroner and buried his remains. In contrast, Reponti evidently died alone in his room and had no relatives to claim him. He was not alone, however, and a friend of the thirty-four-year-old native of France buried Reponti’s remains. ${ }^{202}$

Fires grabbed the attention of newspapers, particularly the one at the Planters' House because of its national fame. Evidently, over 300 people_-guests and employees - escaped the fire and between three and six people died. The GlobeDemocrat reported that the fire began in the kitchen that was adjacent to the hotel, but did not know how the fire started. The reporter listed the employees who escaped from the blaze by name. Just as in the boiler explosion at the Collier White Lead and Oil Works, the Globe-Democrat wrote about the estimated damages to the hotel as well as the insurance. Unlike in other accidents, however, another Globe-Democrat article examined the legal responsibility that the hotel owners had. While hotel guests had successfully sued other hotel owners for failing to provide means of escape from a fire, local attorneys reported that Missouri had no such laws. In this case, even if the hotel owners had been negligent, they could not have been charged with a crime or even subject to a lawsuit. ${ }^{203}$

${ }^{202}$ Carlos Rebori Inquest, January 15, 1883, Case No. 1306, Folder 34, Box 32 (Missouri State Archives microfilm roll C31280), St. Louis City Office of the Coroner-Inquests 1845-1900, Missouri State Archives, Jefferson City, Missouri; Dennis Reponti Inquest, January 15, 1883, Case No. 1307, Folder 35, Box 32 (Missouri State Archives microfilm roll C31280), St. Louis City Office of the CoronerInquests 1845-1900, Missouri State Archives, Jefferson City, Missouri. According to newspaper accounts, Henry Blaney, a man in his 70s and did chores at the hotel, also died in the fire.

${ }^{203}$ Rebori and Reponti Inquests; "Planters' House Burned," St. Louis Globe-Democrat, Sunday, January 14, 1883, 8; “Another Hotel Fire,” Daily Evening Bulletin (San Francisco, California), Monday, January 15, 1883, n.p.; "Death's Messengers," Rocky Mountain News (Denver, Colorado), Monday, January 15, 1883, n.p.; "Multiple News Items," St. Louis Globe-Democrat, Monday, January 15, 1883, 4; 
Fires killed people at home as well as at work and while the press seldom reported on men and women who died at home, fires were a notable exception. A twenty-fouryear-old black woman, Maude Johnson, and her thirteen-year-old daughter, Virginia, perished in a fire that started in a neighbor's home. Some clothing caught fire in one of their neighbors', Annie Williams', kitchen and the fire quickly spread across the apartment building. The blaze destroyed the staircase and the Johnsons' porch, the only way that they could escape, since their tenement had no windows. Annie Williams told Coroner John Frank that she had no idea how the fire began in her kitchen, since she had not used a lamp, matches, or other flammable objects in the room that evening. The coroner also interviewed Johnson's estranged husband, but gained no insight into how the fire began. He rendered a verdict that the Johnsons died from "the result of an accidental burning of the house."204

Only one newspaper wrote an article about the fire, but it was sympathetic, which was unusual in the deaths of poor African Americans. The patronizing tone that the reporter sometimes used, however, was quite common. Like other news articles

\footnotetext{
"Died," St. Louis Globe-Democrat, Monday, January 15, 1883, 5; "Died," St. Louis Globe-Democrat, Tuesday, January 16, 1883, 5; "The Planters' House Dead," St. Louis Globe-Democrat, Tuesday, January 16, 1883, 8; "Coroner's Inquest.: The Verdict in the Cases of the Victims of the Planter's House fire," St. Louis Post-Dispatch, January 15, 1883, 3; "Charred Corpses: The Planters' House Fire Results in the Loss of Three Lives," St. Louis Post-Dispatch, January 15, 1883, 5. Missouri laws held that hotels over two stories had to have a rope or ladder for escape during a fire or other emergency. If a hotel was over three stories tall, it had to have iron balconies. John A. Hockaday, Thomas H. Parrish, et. al, eds. Revised Statutes of the State of Missouri, Volume I. Jefferson City: Carter and Regan, State Printers and Binders, 1879, 1297; David R. Francis, Stephen H. Claycomb, Joseph J. Russell, eds. Revised Statutes of the State of Missouri, Volume I. Jefferson City: Tribune Printing Company, State Printers and Binders, 1889, 1713.

${ }^{204}$ Virginia Johnson Inquest, April 15, 1882, Case No. 791, Folder 42, Box 29 (Missouri State Archives microfilm roll C31279), St. Louis City Office of the Coroner-Inquests 1845-1900, Missouri State Archives, Jefferson City, Missouri. Missouri laws by 1889 required apartment and tenement building owners to provide stairways for residents to escape from fires. David R. Francis, Stephen H. Claycomb, Joseph J. Russell, eds. Revised Statutes of the State of Missouri, Volume I. Jefferson City: Tribune Printing Company, State Printers and Binders, 1889, 1713.
} 
regarding the deaths of men and women who died in accidents, the Globe Democrat focused on the family of the deceased. The Globe Democrat wrote that the Fire Department quickly put out the blaze and prevented "a terrible holocaust." Nonetheless, a mother and her child died — a tragedy emphasized throughout the piece. The article noted details missing from the inquest: that Maude had several other children and had saved them all, in fact. When she returned to get Virginia, the flames were too severe for her to do so and she received her deadly burns trying to rescue her oldest child. The remainder of the article focused on the "miraculous escape[s]" of other residents, as well as how much property they could save. The account concluded with an estimate of the damage to the business owner as well as the amount of insurance he owned and its provider. The last line offered condescending sympathy toward the residents: "Most of the colored families lost their little all in the shape of furniture and clothing." The reporter did not know or speculate as to how the fire began, nor did it mention raising any sort of funds for the men and women who lost everything. ${ }^{205}$

The press and relatives of the deceased were most likely to place blame on others in instances of deaths caused by train and buggy accidents. Vehicular accidents were fairly common in St. Louis the late nineteenth century, and in each inquest, coroners and, in some cases, their juries, sought to determine if the driver was to blame, if the deceased was careless, or if the accident was simply a tragedy with no one at fault. Police usually arrested the drivers of trains and buggies and sometimes held them in jail until the inquests were over and the coroner determined whether they were at fault. Train and buggy accidents featured lengthy inquests with detailed witness testimony, but in most

${ }^{205}$ Johnson Inquest; “A Tenement Horror,” St. Louis Globe-Democrat, Friday, April 14, 1882, 6. 
cases, the coroner determined that the vehicle driver and the company he worked for were not to blame, although at least one family of the deceased planned to sue.

Coroner John Frank and his jury determined that one individual, a train engineer, caused a deadly accident, but they did not blame the train company for whom he worked or believe that the death was anything but an accident, as was typical in deaths caused by vehicles. Friedrich Brueckner died while crossing the railroad tracks on his way home from a day of work at a local brickyard on August 12, 1883. The forty-eight-year-old German immigrant he saw and heard the whistle of an engine that was, by all accounts, speeding along the track. Brueckner tried to run across the tracks to escape the oncoming engine, but the train hit and killed him nonetheless. The train engineer, John Leahy, admitted to speeding because a freight train was behind him and he was also running a few minutes late. His wife, Ottilia, saw a crowd running to the train tracks and joined them, where she saw "that my husband had been run over." Witnesses told the coroner that no watchman was posted on this private railroad crossing at the time of Brueckner's death and, other cases reveal that watchmen were not consistently posted at any railroad crossings in St. Louis. Watchmen would warn pedestrians and drivers of oncoming trains before they crossed the tracks - the only protection in an era long before railroad crossing barriers. $^{206}$

Local newspapers wrote sympathetic, but brief, accounts of Brueckner's death and, unlike in most cases, the Globe-Democrat and Post-Dispatch even called for charity

${ }^{206}$ Friedrich Brueckner Inquest, August 13 and 14, 1882, Case No. 1024, Folder 125, Box 30 (Missouri State Archives microfilm roll C31279), St. Louis City Office of the Coroner-Inquests 18451900, Missouri State Archives, Jefferson City, Missouri; According to Carl Gersuny, workplace regulations were often contradictory. They maintained that employees should use caution, but simultaneously sent memos directing employees to work faster-particularly with railroad workers. Carl Gersuny, Work Hazards and Industrial Conflict (Hanover, N.H.: University Press of New England, 1981): 27. 
for Brueckner's family. He left behind a wife and four children who were, according to the Post-Dispatch, "absolutely starving." Both newspapers spent as much space discussing Brueckner's family as they did the details of the accident, which they kept brief. The call for charity reveals that Brueckner's family did not expect to receive any aid from the railroad company or from life insurance. ${ }^{207}$

Although in most cases, no one was held liable for deadly vehicular accidents, in some cases, family members of the deceased threatened to sue for negligence, indicating that at least some people expected the civil courts to hold individuals or companies accountable for deaths. George M. Grasser's family told local newspaper reporters that they would sue because he died after being run over by a mule and wagon on April 26, 1882. Grasser differed from many men and women who died from accidental deaths because he was a prominent attorney and judge from Ohio. His class position and reputation are likely the reasons why his death was the basis for the only incident of a possible civil suit for an accident in this study. ${ }^{208}$ Grasser was walking with Charles B. Shaffer around 8:30 p.m. on the night of April 24, 1882, when Shaffer noticed a wagon and mules approaching and jumped out of the way. Grasser did not see or hear the vehicle, however, and was run over. The driver, Michael Higgins, had been doing two jobs: driving and making change for customers and giving them tickets—-something a conductor should have been doing. While he did not testify that he was distracted, he likely was, and was certainly unable to stop the mules when he saw Grasser. The dark night made it impossible for Higgins to see Grasser and Shaffer until he was very close to

207 "Brueckner's Death," St. Louis Post-Dispatch, August 14, 1882, 5; "The Brueckner Inquest," St. Louis Globe-Democrat, Tuesday, August 15, 1882, 10; "Brueckner's Death," St. Louis Post-Dispatch, August 14, 1882, 5.

${ }^{208}$ Mike Everman found no record of a lawsuit, despite the family's plans to do so. 
them. After the accident, he immediately left his vehicle, tried to help Grasser, and asked an officer to arrest him (as was standard in vehicular accidents). Coroner Frank did not blame the driver and ruled the death to be "the result of an accident."

Grasser's family did not blame the driver, either, but they did blame his employer, the streetcar company, and they also believed that the coroner was biased, but there is no evidence to substantiate this claim. Grasser's wife and three children sought to sue the company for two reasons. First, they believed that the company was negligent because its driver was performing the duties of both a conductor and a driver, which distracted him. Second, they believed that Coroner Frank "favored the railroad company at the inquest," which is why he did not hold the driver or his employer responsible for Grasser's death. The family's attorney also argued that the inquest should have been held before a jury. Although there is evidence that the driver was, in fact, distracted, there is no evidence that the coroner favored the railroad. Indeed, advocates for Grasser may have tried to influence Coroner Frank because the local Masonic lodge offered to pay the inquest fees. Frank accepted their payment, but immediately deposited the money into the city's Treasury account, perhaps to avoid any claims of impropriety. While Frank did not hold a jury inquest, it is unlikely that a jury would have rendered a different verdict, despite what the Grasser family believed. As the cases in this chapter demonstrate, coroners and juries almost never held employers accountable for accidental deaths. Perhaps this realization is why the proposed lawsuit came to fruition. ${ }^{210}$

\footnotetext{
${ }^{209}$ George Grasser Inquest, April 26 and 27, 1882, Case No. 814, Folder 65, Box 29 (Missouri State Archives microfilm roll C31279), St. Louis City Office of the Coroner-Inquests 1845-1900, Missouri State Archives, Jefferson City, Missouri.

${ }^{210}$ Grasser Inquest; "A Sad Accident,” St. Louis Globe-Democrat, Tuesday, April 25, 1882, 8; "Casualties," The Daily Inter Ocean (Chicago, Illinois), Thursday, April 27, 1882, 5; "Relief in Death," St. Louis Globe-Democrat, Thursday, April 27, 1882, 6; "The Late Judge Grasser," St. Louis Globe-Democrat, Friday, April 28, 1882, 8; "The Grasser Inquest," St. Louis Globe-Democrat Sunday, April 30, 1882, 2;
} 
In some cases, particularly in accidents that killed women, investigating coroners and witnesses wondered if the victims were not responsible for their deaths because of insanity. While the inquest into the death of forty-eight-year-old German immigrant Agnes Redman was similar to those conducted into the deaths of men, one difference stands out: the coroner asked the witnesses if she was insane. While witnesses often testified to whether the deceased was under the influence of alcohol at the time of their deaths caused by vehicles, only in the Redman case did anyone mention her state of mind - perhaps as a cause for her distraction or maybe to determine if she committed suicide.

Like Grasser and Brueckner, Agnes Redman was out walking when a train struck and killed her on the morning of November 4, 1885. Unlike those men, however, Redman was not just walking near the railroad tracks or a buggy, but on the tracks. She had just moved to a new home six weeks earlier, which could explain why she used that route; perhaps it was the only way she knew to get home. Redman was on her way home from buying milk when a train approached, blowing its whistle to warn her. She tried to get off the track, but did not make it in time. The engineer told Deputy Coroner Thomas Hennessy that as the train approached, Redman "appeared to have lost her presence of

“Judge Grasser," St. Louis Post Dispatch, April 26, 1882, 7; “Judge Grasser’s Death," St. Louis Post Dispatch, April 27, 1882, 4. 
mind and was slipping from one side of the track to the other." W.A. Vanclike, the engineer, blew the whistle and tried to reverse the train. Redman did not try to get off the track even as he rang the bell and blew the whistle until the engine was quite close. Margaret Meyer, the woman who sold Redman the milk she was bringing home, told the coroner that she never heard the engine's bell ringing, however, only the whistle, and added that Redman was both sober and "in her right mind." Lewis Johnson, who saw part of the accident, testified that the engine tried to reverse itself or stop and blew its whistle. Redman had ample time to get off of the track, he claimed, but she did not. Agnes Redman left behind a husband and ten children. Unlike in the death of Friedrich Brueckner, newspapers did not call for charity for Redman's family and, in fact, did not report on her death at all. ${ }^{211}$

While witnesses and investigators debated whether men and women who were struck by vehicles were to blame at all, some cases were more complicated because the deceased may have been at fault, particularly by drinking. Men and women who fell to their deaths were often drinking before they died. Thomas Hayes, a thirty-nine-year-old Irish immigrant who worked as a tailor, died from a skull fracture after falling down a staircase, possibly while drunk between midnight and 1:00 am on February 16, 1876. Coroner George Dudley interviewed three witnesses and held a jury inquest to determine

${ }^{211}$ Agnes Redman Inquest, November 4, 1885, Case No. 479, Folder 168, Box 44 (Missouri State Archives microfilm roll C31283), St. Louis City Office of the Coroner-Inquests 1845-1900, Missouri State Archives, Jefferson City, Missouri.

These are just three of several vehicular accidents. See also: Franz Geiger Inquest, June 5, 1876, Case No. 109, Folder 113, Box 8 (Missouri State Archives microfilm roll C31273), St. Louis City Office of the Coroner-Inquests 1845-1900, Missouri State Archives, Jefferson City, Missouri; Jacob Johnson Inquest, December 8, 1882 Case No. 1221, Folder 121, Box 31 (Missouri State Archives microfilm roll C31279), St. Louis City Office of the Coroner-Inquests 1845-1900, Missouri State Archives, Jefferson City, Missouri; John Nolan Inquest, January 1, 1883, Case No. 1273, Folder 1, Box 32 (Missouri State Archives microfilm roll C31280), St. Louis City Office of the Coroner-Inquests 1845-1900, Missouri State Archives, Jefferson City, Missouri. 
how Hayes died. His wife, Mrs. Ellen Hayes, told the coroner and his jury that her husband was sober on the day of his death. The prefix "Mrs." is noteworthy because coroners almost never used the prefix "Mr." or "Mrs." for deceased men and women or the witnesses whom they interviewed and they indicate a sign of respect. Thomas Hayes and his wife had recently reunited after seven years apart, when Thomas lived in Chicago. His wife said that Thomas had been "home" with her and their children for about a month. Ellen said that her husband would sometimes go on drinking sprees and had been drinking a few days before his death, but she believed he was sober on the day of his accident. Fannie Hartley and Officer Patrick Weldon testified to finding Hayes' body, but no one saw Hayes fall down the stairs, although Hartley heard it. A jury determined that Hayes had died from "accidentally falling down the Stairway" and made no mention of his drinking, probably because they had no evidence to believe he was, despite his history. No one saw him drinking before his death, either. As with many accidents of men and women who died alone from accidents, newspapers did not write any accounts of Hayes' death. ${ }^{212}$

The inquest into the death of thirty-four-year-old Wesley Morrell differed from that of Thomas Hayes because Deputy Coroner George M. Peck only interviewed two witnesses and did not hold a jury inquest. Race may have played a role in Peck's decision because Morell was black, but Peck may have conducted a shorter inquest because the circumstances of Morrell's accident were different from Hayes'. Like Hayes, Morrell was alone when he fell, but, unlike Hayes, he lived for nearly two weeks after his

${ }^{212}$ Thomas Hayes Inquest, February 16, 1876, Case No. 58, Folder 62, Box 8 (Missouri State Archives microfilm roll C31272), St. Louis City Office of the Coroner-Inquests 1845-1900, Missouri State Archives, Jefferson City, Missouri. 
accident. Morell may have been drinking before he fell from a third-story window of the Marine Hospital where he worked. Morrell was married and his wife, Fanny, told Deputy Coroner George M. Peck that her husband was sitting in the window and drinking a beer to cool off on the night of May 3,1883. When he went to climb back into the room, she said, he fell out of the window. Dr. D.V. Dean, who treated Morrell, told the coroner that Morrell "did not know how he had fallen"- a statement that differed from his wife's testimony because of its lack of detail. Peck did not appear to consider Morrell's death to be a suicide because he did not ask about his state of mind before his death. His family held services at a Catholic church and buried him in Calvary Cemetery, a Catholic cemetery, so it is possible that Morrell or his wife tried to conceal a suicide. Peck rendered a verdict of "injuries received...by falling from a window," not explicitly calling it an accident, but implying it with the verdict and testimony. Newspaper reports give no additional insight into the case, as they offered articles of only a sentence describing Morrell's death, but, as was typical, being sure to note that he was “colored." 213

Sometimes, men and women who had physical disabilities died from accidents resulting from those disabilities and, as in the cases of falls, sometimes alcohol may have contributed to their deaths. As in other cases in which men and women died alone, newspapers did not report on many of these deaths. In one case, the coroner and

${ }^{213}$ Wesley Morrell Inquest, May 16, 1883 Case No. 102, Folder 101, Box 33 (Missouri State Archives microfilm roll C31280), St. Louis City Office of the Coroner-Inquests 1845-1900, Missouri State Archives, Jefferson City, Missouri; "Local Brevities," St. Louis Globe-Democrat, Tuesday, May 15, 1883, 8; "Yesterday's Burial Permits," St. Louis Globe-Democrat, Thursday, May 17, 1883, 12;

"Died," St. Louis Globe-Democrat, Thursday, May 31, 1883, 7. For a similar case, but of a man who died after falling off a horse, see: Henry Payne Inquest, July 3, 1881, Case No. 190, Folder 85, Box 25 (Missouri State Archives microfilm roll C31277), St. Louis City Office of the Coroner-Inquests 1845-1900, Missouri State Archives, Jefferson City, Missouri. 
reporters blamed the disability for a woman's deadly accident, although another person's actions contributed to her death. Of four men and women who died from accidents caused by physical disabilities, three had epilepsy, an illness that also contributed to the deaths of men and women in Chapter Two, but was overlooked because these men and women died while intoxicated. ${ }^{214}$ One of the men and women who died from epilepsy was Matilda Pate Warner, alias Flo. Brady, a high-class prostitute who suffered a brain injury after falling during an epileptic seizure. Deputy Coroner Thomas Hennessy interviewed six witnesses - a fairly high number for a woman of ill-repute - to determine how Warner died during the early morning hours of March 8, 1885. Her next-doorneighbor, Cora Rapp, had known the twenty-eight-year-old for four years, since she had lived in St. Louis. She was divorced and earned her living as a prostitute. Rapp told the coroner that Warner "was subject to fits" when "under the influence of liquor," which she often was. She often fell during these seizures. Rapp knew something was wrong on March 8 when Warner's servant knocked on her door and received no answer. Warner had been drinking the night before, so Rapp was worried that she had suffered a seizure and called the police to force his way into Warner's apartment. She was unconscious, on the floor, with an injury on her face. Dr. Williams treated her, but the medicine he gave her for the concussion did not help. She died at the hospital. Rapp told the coroner that Warner was not fighting with anyone - to rule out a homicide. Other witnesses

${ }^{214}$ For two cases of men who died from accidents that occurred during epileptic seizures, see: Louis Hohenschild Inquest, October 29, 1880, Case No. 2362, Folder 43, Box 24 (Missouri State Archives microfilm roll C31277), St. Louis City Office of the Coroner-Inquests 1845-1900, Missouri State Archives, Jefferson City, Missouri; “Died," St. Louis Globe-Democrat, Sunday, October 31, 1880, 5; "Sad Death.: An Epileptic's Means of Safety Causes His Death at Night and Alone," St. Louis Post-Dispatch, October 29, 1880, 4; "Died," St. Louis Globe-Democrat, Sunday, October 31, 1880, 5; For a similar case, see: Ferdinand Bruner Inquest, October 7 and 8, 1880, Case No. 2313, Folder 144, Box 23 (Missouri State Archives microfilm roll C31277), St. Louis City Office of the Coroner-Inquests 1845-1900, Missouri State Archives, Jefferson City, Missouri. 
corroborated Rapp's, with an interesting addition from the treating physician, Dr. Dean, at the City Hospital: she had several burns "along the lower limbs and upon back" which were "apparently produced at some previous time by hot irons." Perhaps she had been abused by her former husband, lover, or client. ${ }^{215}$

Despite evidence that the use of alcohol contributed to Warner's death, Hennessy rendered a verdict of an accidental death, "compression of the brain the result of a fall," with no mention of her drinking. Her autopsy, performed by Dr. James C. Nidelet, determined that she died from a concussion, but had "evidence of use of alcoholic stimulants." Hennessy's verdict differs dramatically from that of Bridget Tracy, who died after half-falling out of bed after a night of drinking. Like Warner, Tracy often suffered epileptic seizures after she drank alcohol, but unlike Warner, Tracy had fewer witnesses to testify before the coroner and he did not order an autopsy. Unlike the coroner, the only newspaper to report her death mentioned that she was intoxicated when she fell and also mentioned that she lived in a brothel. While Warner worked as a highclass prostitute, she was still a prostitute and newspapers almost never wrote sympathetic accounts for such women. ${ }^{216}$

In contrast to Warner, the coroner and reporters highlighted Margaret Loeb's disability as the cause of her death, even though there were other factors that contributed

${ }^{215}$ Matilda Warner Inquest, March 8, 1885, Case No. 1544, Folder 129, Box 41 (Missouri State Archives microfilm roll C31282), St. Louis City Office of the Coroner-Inquests 1845-1900, Missouri State Archives, Jefferson City, Missouri.

216 Warner Inquest; “Local Brevities," St. Louis Globe-Democrat, Monday, March 9, 1885, 6; Hennessy also conducted the brief inquest into the death of Bridget Tracy, discussed in Chapter Two, who also often suffered from epileptic seizures after drinking, but whose death Hennessy determine was caused by alcoholism. Bridget Tracy Inquest, July 6, 1885, Case No. 180, Folder 50, Box 43 (Missouri State Archives microfilm roll C31283), St. Louis City Office of the Coroner-Inquests 1845-1900, Missouri State Archives, Jefferson City, Missouri. Although her name is recorded as "Tracy," in the inquest title, witnesses and other sources spelled her name "Tracey." 
to her death. Loeb was a fifty-year-old German housewife, respected in her community, and died not from epilepsy, but because she was blind. Loeb was hanging laundry to dry in her yard on September 7, 1883, when she fell into a large cistern whose cover was not attached, probably because someone moved it to the side and did not replace it after using the well. Loeb did not let her blindness top her from performing her daily chores and her stepdaughter and neighbors told Deputy Coroner George Peck that she was careful, even though she knew her home and yard well. Neighbors heard her fall into the unprotected well and tried to save her, but she died a few minutes after they pulled her from the well. Both the coroner and a reporter attributed her death to her blindness, not the fact that someone did not replace the well cover. Peck determined that "Loeb, being blind" fell "into an open cistern... and being drowned in the water therein." A Globe-Democrat reporter came to a similar conclusion in his two-sentence article, highlighting Loeb's disability, particularly by calling her "the blind woman." Like the coroner, he made no mention of the fact that a neighbor neglected to cover the cistern after using it. While Loeb's disability contributed to her death, she had also lived a long, healthy life with it and may have continued to do so if someone had left the well covered. ${ }^{217}$

Finally, in some cases people suffered accidents that stemmed from illnesses and these are the few cases in which no one truly was to blame. Twenty-eight-year-old Flora Deismer technically died from an accident because she fell out of bed on July 15, 1885. But she was bedridden because she was suffering from typho-malarial fever. Her grandmother adjusted the pillows for her and left the room to get some ice. Her ten-year-

${ }^{217}$ Margaret Loeb Inquest, September 8, 1883, Case No. 395, Folder 46, Box 35 (Missouri State Archives microfilm roll C31280), St. Louis City Office of the Coroner-Inquests 1845-1900, Missouri State Archives, Jefferson City, Missouri; “Local Brevities," St. Louis Globe-Democrat, Sunday, September $9,1883,7$. 
old sister was present when Deismer became dizzy and fell from her bed, sideways. It was a concussion from her fall from bed, not her illness, that killed Deismer. Corner Sylvester Nidelet rendered a verdict of an "accident" from a concussion, but noted that she had been "confined to the bed for three weeks from the effects of Typho Malarial fever." The Globe-Democrat wrote two accounts about her, probably because she suffered from an illness, and also because she was a "beloved wife." Her death did not warrant a sensationalistic account, but because she was a respected member of the community, reporters did write about her death, which they often did not., particularly for men and women who died at home alone. ${ }^{218}$

Flora Deismer differed from most of the men and women who died from accidents: she suffered an illness that contributed to her accident and no one's actions caused her death. But she was similar to the other men and women in this chapter because she had a close relationship with her family and her relatives testified on her behalf to the coroner-something less common when people died by homicide, alcoholrelated deaths, suicide, or complications from abortions. Although the men and women who died because of accidents generally had families — and newspapers and coroners highlighted that fact - few provisions existed for those who were left behind after an accident. Coroners and their juries seldom held employers or train or buggy drivers accountable for deaths they may have contributed to, albeit unintentionally, and families had few resources to help them cope financially outside of charities. While companies

${ }^{218}$ Flora Deismer Inquest, July 16, 1885, Case No. 211, Folder 81, Box 43 (Missouri State Archives microfilm roll C31283), St. Louis City Office of the Coroner-Inquests 1845-1900, Missouri State Archives, Jefferson City, Missouri; “Died," St. Louis Globe-Democrat, Friday, July 17, 1885, 5; “Coroner's Cases,” St. Louis Globe-Democrat, Friday, July 17, 1885, 10. 
had insurance to protect their financial losses from fires and explosions, they did not have to provide for a worker's family after an employee died from those same fires or explosions. Newspapers lamented the deaths of men who were breadwinners or women who were mothers, but at the same time, they did not believe that a system which allowed dangerous workplaces and roads to exist that caused some of these deaths were at fault. People took risks when they drank, crossed railroad or trolley tracks, or went to work and, although it was tragic if they died doing those things, most men and women did not believe that it was a failure of the system. It was not until the early twentieth century that popular opinion changed to believe that employers, the city, and others should protect people's safety and progressive reformers worked to change laws to do so. But in St. Louis between 1875 and 1885, most men and women believed that no one was to blame in these tragedies- preventable or not. 


\section{Chapter Six \\ Not as Simple as Disease: Coroners' Verdicts of Natural Deaths}

On the morning of September 15, 1883, Mary Smith knocked on her neighbor's door but her neighbor, Kate Williamson, did not respond. Smith called on Williamson around 8:00 that morning to ask her about a fight that she had overheard the night before between Williamson and her lover, Billy McCue. After hearing no response from Williamson, Smith used her key to unlock Williamson's door to check on her friend. Smith found Williamson lying on her floor, dead. She called the coroner to investigate because the thirty-eight-year-old washerwoman had died unexpectedly and under suspicious circumstances. Police arrested McCue until Deputy Coroner George Peck completed his inquest, complete with an autopsy performed by Dr. James C. Nidelet. Despite testimony from neighbors and relatives that McCue had punched, shoved, and kicked Williamson the night before, Peck found that the beating did not kill Williamson. Instead, he rendered a verdict of a natural cause of death: congestion of the heart and lungs. ${ }^{219}$

The lengthy investigation into the death of Kate Williamson was unusual in investigations into natural deaths, that is, deaths caused by illnesses or disease. Of the fifteen deaths examined in this chapter, Williamson's is one of only two in which another person was suspected of causing or contributing to these deaths. In most cases,

\footnotetext{
${ }^{219}$ Kate Williamson Inquest, September 15, 1880, Case No. 408, Folder 59, Box 35 (Missouri State Archives microfilm roll C31280), St. Louis City Office of the Coroner-Inquests 1845-1900, Missouri State Archives, Jefferson City, Missouri. Peck was the Deputy Coroner under Coroner Sylvester L. Nidelet. Dr. James Nidelet was Sylvester's brother and routinely performed autopsies for the coroner's office.
} 
investigating coroners quickly determined that neither the deceased nor any other person was responsible for deaths caused by illness or disease. Despite these natural causes, however, a close examination of the deaths of these men and women reveals that even natural deaths are more complicated than they initially appear. Some of these men and women experienced exacerbating contributors or causes for their deaths, such as sunstrokes. Others may have died in part because of the acts of other people, including medical malpractice, or, in the death of Kate Williamson, an assault from her lover.

Coroners investigated most of these deaths fairly quickly, but while brief inquests and verdicts of disease or other natural causes of death make these cases appear to be simple, most were not. Some cases feature verdicts that were not entirely accurate, or they have times of death and other details that do not match witness testimony. In some cases, the verdicts of natural causes of death reflect a lack of thorough investigation rather than a truly easy-to-solve case, evidenced in part by the fact that deputy coroners investigated over half of these deaths with no oversight from the supervising coroners. ${ }^{220}$ Deputy coroners had less training than did their supervisors. Coroners were more likely to investigate suspicious deaths than were deputies—such as potential homicides. Coroners and their deputies also seemed less concerned about rendering an accurate cause of death than in other cases. The reason for this difference is likely because no one else was responsible for these deaths in most cases. Unlike suicides, homicides, and some deaths caused by abortions and accidents, in most of these cases, there was no evidence that anyone else caused these deaths and, as such, a verdict would not implicate anyone else in a crime.

${ }^{220}$ Deputy coroners investigated at least eight of the fifteen cases. At least one deputy was acting coroner, though, so this partially explains the disparity. 
As with deaths caused by accidents, the men and women who died from disease and illnesses tended to be older than those who died by suicide, abortion, alcoholism, and homicides, and most had close relationships with their families and communities. They ranged in age from thirty to forty-seven and were primarily working-class. Few were native-born white men and women; most were immigrants or African Americans. As with the other men and women in this study, however, their reputations mattered. While newspaper articles seldom honored or condemned the dead, they wrote especially long and sympathetic accounts of those who were respected members of the community. They also commented on the poor reputation of some of these men and women. Newspaper reporters wrote articles about most of the deaths of these men and women, even if they only briefly noted that they died, unlike the sensationalistic accounts of suicides, homicides, and some deaths caused by abortions. Families and communities mourned these deaths and generally saw them as tragic, but not all were unexpected, perhaps explaining these brief newspaper accounts.

In some cases, relatives, friends, and physicians told investigating coroners that the deceased had been suffering from illnesses, such as cancer, jaundice, or consumption, but in others, witness testimony contradicted the coroner's verdict. Such was the case for George Vanderheide, a thirty-six-year old German blacksmith who died suddenly on October 17, 1880. Coroner Hugo Auler investigated his death because of his young age and because no physician was present when he died, not because Vanderheide had died under suspicious circumstances. Auler interviewed two witnesses-Vanderheide's wife and a physician who had treated him a few times. Both told Auler that Vanderheide suffered from digestive issues — stomach pain, vomiting, diarrhea, and, Dr. Heidemann 
said, constipation. In fact, Vanderheide died while kneeling in the water closet--where his wife found him. Kate Vanderheide told Auler that he had complained of stomach ailments since the summer and had lately not been eating. Evidently, Auler did not know what killed Vanderheide, because he ruled his death to be the "result of cerebral apoplexy," apparently a catchall term for sudden deaths. Auler did not order an autopsy or conduct any other tests, probably because he knew that Vanderheide had died from some sort of illness or disease and no one else was accountable for his death. Despite evidence of some sort of stomach ailment, Auler rendered a quick verdict and probably only investigated the death because no medical doctor was present when he died because he noted in his verdict that he died with "no medical attendant." Newspaper accounts do not offer any additional insight into Vanderheide's life or death, as a lone report simply recounted the facts of his death in a short article. ${ }^{221}$

Other deaths caused by illnesses differ from Vanderheide's because the verdict was in line with the evidence provided by witnesses and treating physicians. The press either wrote brief accounts of their deaths, or, in the case of a black woman who worked as a prostitute, no articles at all. ${ }^{222}$ But the death of Dr. Peter V. Schenck differed because he was a respected gynecologist in the city. Coroner S.L. Nidelet investigated

${ }^{221}$ George Vanderheide Inquest, October 17, 1880 Case No. 2332, Folder 13, Box 24 (Missouri State Archives microfilm roll C31277), St. Louis City Office of the Coroner-Inquests 1845-1900, Missouri State Archives, Jefferson City, Missouri; “Coroner's Cases," St. Louis Globe-Democrat, Monday, October 18, 1880. 8.

${ }^{222}$ Lucinda Adams died from consumption (tuberculosis) and is perhaps the only prostitute in my study who did not allegedly commit suicide. Lucinda Adams Inquest, January 3, 1883, Case No. 1280, Folder 8, Box 32 (Missouri State Archives microfilm roll C31280), St. Louis City Office of the CoronerInquests 1845-1900, Missouri State Archives, Jefferson City, Missouri. For other deaths caused by disease, see: Josephine Laddy Inquest, December 22, 1882, Case No. 1250 Folder 150, Box 31 (Missouri State Archives microfilm roll C31279), St. Louis City Office of the Coroner-Inquests 1845-1900, Missouri State Archives, Jefferson City, Missouri; Emilien Palmer Inquest, August 18, 1878, Case No. 880, Folder 66, Box 15 (Missouri State Archives microfilm roll C31274), St. Louis City Office of the CoronerInquests 1845-1900, Missouri State Archives, Jefferson City, Missouri. 
the forty-seven-year-old's sudden death on March 11, 1885 and concluded that the physician died from "convulsions due to granular kidney" disease after interviewing two witnesses and ordering an autopsy. His wife was too distraught to testify, so her sister told the coroner that Schenck had been suffering from stomach pains all day. He felt better before going to bed, but died some time that night, with his wife at his side. ${ }^{223}$

Because of his prominence, several newspapers wrote accounts of his death, detailing his career and education. In most cases, the press wrote short accounts simply recounting the facts of the deaths of these men and women and, in some cases, giving information about their funerals. But reporters for the Post-Dispatch and GlobeDemocrat wrote a combined seven articles about Schenck, the former Superintendent of the Female Hospital and Health Commissioner. The press coverage of Schenck differed dramatically from the physicians who performed abortions discussed in Chapter Two, although he, too, worked as a gynecologist. A local medical society even met to create a memorial for Schenck and numerous colleagues, relatives, and friends attended his services at the Second Presbyterian Church. As with the other men and women in this study, mourners remembered Schenck for the way he lived and did not focus on the way he died. ${ }^{224}$

Men were not the only ones whose causes of death were more complicated than their verdicts suggest. Deputy Coroner Thomas Hennessy believed that Mrs. S.A. Wood,

${ }^{223}$ Peter Scheck Inquest, March 11, 1885, Case No. 1553, Folder 138, Box 41 (Missouri State Archives microfilm roll C31282), St. Louis City Office of the Coroner-Inquests 1845-1900, Missouri State Archives, Jefferson City, Missouri.

224 “Died," St. Louis Globe Democrat, Thursday, March 12, 1885, 7; “The Death Roll," in "Multiple News Items," St. Louis Globe-Democrat, Thursday, March 12, 1885, 8; "City News," St. Louis Post-Dispatch, March 12, 1885, 8; “City News," St. Louis Post-Dispatch, March 13, 1885, 8; ““"The Death Roll," St. Louis Globe-Democrat, Saturday, March 14, 1885, 8; "The Schenck Obsequies," St. Louis Globe Democrat, Sunday, March 15, 1885, 8; “The Medical Society," St. Louis Globe Democrat, Sunday, March $15,1885,11$. 
a thirty-four-year-old housewife, died from hysterical convulsions, even though her son and neighbor told him that she suffered from epilepsy. Mary Parker, Wood's neighbor and landlady, found Wood dead on the floor on the afternoon of July 24, 1885. Parker told the coroner that Wood had been "subject to fits...they looked like epileptic fits" during the entire seven years that she had known Wood. Wood saw Dr. Pitzer, who called the "fits" "convulsions of a hysterical nature," and he did not believe that she suffered from epilepsy. Wood evidently experienced these convulsions more often when she was pregnant, both Parker and Wood's son told the coroner, and she had been two months pregnant when she died. Dr. Pitzer and Parker also told the coroner that Wood treated herself for frequent constipation with a syringe, which she may have done on the day she died, as a syringe was inside a near-empty bowl near her body. Deputy Coroner Hennessy trusted the judgment of Dr. Pitzer when he rendered his verdict, even though he could not determine how Wood died. Hennessy did not order an autopsy, but determined that Wood died from hysterical convulsions-seizures that resulted from hysteria. ${ }^{225}$

Some men and women died not because of an illness or disease, but because of an unbearable heat wave during July of 1881. Unlike with most natural deaths, the St. Louis press wrote numerous accounts of these sunstroke deaths and even listed the names of nearly everyone who died. Some of these men and women were discussed in Chapter Two because investigating coroners determined that they died not only because of the heat, but also because of their drinking. In four cases in this study, however, investigating coroners decided that heat alone killed some men and women. The

${ }^{225}$ Mrs. S. A. Wood Inquest, July 25, 1885, Case No. 250, Folder 120, Box 43 (Missouri State Archives microfilm roll C31283), St. Louis City Office of the Coroner-Inquests 1845-1900, Missouri State Archives, Jefferson City, Missouri. 
coroner's office was overwhelmed with heatstroke deaths and this is likely why they investigated these four cases fairly briefly. Despite being overloaded with cases, however, coroners determined that some men and women died from heatstroke alone, while others died from sunstroke and alcohol consumption. ${ }^{226}$ Of the four men and women who allegedly died from "heat and liquor," three were working-class or poor and were estranged from their families. The fourth was a respectable widower who lived with his in-laws. In each case, witnesses told the investigating coroners about the deceased's drinking, leading them to render verdicts of sunstroke and "intemperance."227

The different verdicts among men and women who died from sunstroke illustrate that the investigating coroner, the reputation of the deceased, and the witnesses who testified impacted verdicts, even in cases in which men and women died of the same cause, in this case, sunstroke. Of the four men and women who allegedly died only from sunstroke, two had relatives who testified before the coroner, one had a neighbor, and one had an acquaintance. The witnesses knew these four men and women fairly well and none of them told the coroner that the deceased had been drinking recently. In contrast, witnesses in each of the three sunstroke deaths examined in Chapter Two told the coroner that the deceased had been drinking shortly before they died. In addition, Deputy Coroner Praedicaw was more likely to render verdicts of sunstroke and intemperance than was his supervisor, Coroner John N. Frank. Two of the three men and women who

${ }^{226}$ I sampled four cases of each for this study.

${ }^{227}$ See: Ellen Maloney Inquest, July 12, 1881, Case No. 241, Folder 42, Box 26 (Missouri State Archives microfilm roll C31278), St. Louis City Office of the Coroner-Inquests 1845-1900, Missouri State Archives, Jefferson City, Missouri; Ellen Maloney Inquest, July 12, 1881, Case No. 241, Folder 42, Box 26 (Missouri State Archives microfilm roll C31278), St. Louis City Office of the Coroner-Inquests 1845-1900, Missouri State Archives, Jefferson City, Missouri; Amanda McKinley Inquest, July 12, 1881, Case No. 240, Folder 41, Box 26 (Missouri State Archives microfilm roll C31278), St. Louis City Office of the Coroner-Inquests 1845-1900, Missouri State Archives, Jefferson City, Missouri. 
received verdicts of sunstroke and intemperance were lower-class-a servant and prostitute, while the third was a middle-class salesman. They were also younger than those who died of sunstroke alone, ranging in age from twenty-six to thirty-five, while those who died only of sunstroke were between thirty-eight and forty-seven. In addition to witness testimony that the deceased had been drinking, the differences in reputation, age, occupation, and investigating coroner explain the different verdicts.

Coroners were overwhelmed with heatstroke deaths and often interviewed just one or two witnesses to determine the cause of death before moving on, but they still distinguished between deaths caused by sunstroke alone and those caused by alcohol use as well. Mary Maher and Patrick Kelleher were two of several men and women who died from heatstroke on July 11, 1881, having complained of the heat shortly before her sudden death. Like many others, Maher left behind a husband and child and her husband told Coroner Frank about his wife's complaint of the heat. The thirty-eight-year-old Irish woman left behind a child. Patrick Kelleher died the same day from sunstroke. Coroner Frank talked to two people, Kelleher's brother and a boardinghouse keeper, to determine that Kelleher died "from the effects of sunstroke" as well as to gather his vital information-age, occupation, etc. No one told the coroner that Kelleher had complained of the heat, but he was ill when he went to bed at 7:00 that night. Considering at least twelve people died from the heat that day, Frank determined that forty-seven-year-old Kelleher had, too, despite having little evidence. ${ }^{228}$ The St. Louis press wrote numerous

${ }^{228}$ Mary Maher Inquest, July 11, 1881, Case No. 225, Folder 26, Box 26 (Missouri State Archives microfilm roll C31278), St. Louis City Office of the Coroner-Inquests 1845-1900, Missouri State Archives, Jefferson City, Missouri; David Kelleher Inquest, July 11, 1881, Case No. 224, Folder 25, Box 26 (Missouri State Archives microfilm roll C31278), St. Louis City Office of the Coroner-Inquests 18451900, Missouri State Archives, Jefferson City, Missouri. See also: Annie Lockey Inquest, July 13, 1881, Case No. 239, Folder 40, Box 26 (Missouri State Archives microfilm roll C31278), St. Louis City Office of the Coroner-Inquests 1845-1900, Missouri State Archives, Jefferson City, Missouri; J.W. McElvain 
articles about the deadly heat wave, the crowded conditions of the morgue, and listed nearly all of the dead in several articles. ${ }^{229}$

While deaths caused by known illnesses and sunstroke were fairly simple for coroners to investigate, not all deaths classified as natural were easy to solve. In some cases, men and women may have died because of medical malpractice, but coroners did not hold physicians accountable because either they lacked evidence or did not suspect wrongdoing. Deputy Coroner Cornelius MacBride did mention that a medicine given by a physician may have accelerated the death of thirty-seven-year-old Frank Anderson on October 24, 1880, however. The African American laborer sought treatment from Dr. Baurichter to treat him for syphilis. The disease had ravaged his body, according to the autopsy performed by Dr. James Cooper, but Cooper still could not determine what caused Anderson's death. Deputy Coroner MacBride suspected that the course of treatment may have "hastened" Anderson's death and interviewed Dr. Baurichter to determine whether he caused Anderson's death. MacBride learned that Baurichter had no medical degree and was not licensed to practice medicine, but had been treating patients for nineteen years anyway. The physician told the coroner the exact amounts of every medicine he gave Anderson and noted that he made all of his own medications. MacBride did not have enough evidence to conclude that Baurichter caused Anderson's

Inquest, July 11, 1881, Case No. 226, Folder 27, Box 26 (Missouri State Archives microfilm roll C31278), St. Louis City Office of the Coroner-Inquests 1845-1900, Missouri State Archives, Jefferson City, Missouri. In McElvain's case, someone gave him whiskey before he died, but another friend stopped him, so it did not appear that he was intoxicated. Evidently, this friend gave him whiskey because he felt ill. 229 "Hot as Hades," St. Louis Post-Dispatch, July 8, 1881, 4; “The Sun's Sufferers," St. Louis Globe-Democrat, Monday, July 11, 1881, 5; "Slaughtered by the Sun," St. Louis Post-Dispatch, July 12, 1881, 5; "Coroner's Cases." Crowded Condition of the City Morgue During the Hot Spell," St. Louis PostDispatch, July 13, 1881, 4; "Killed By Heat," St. Louis Post-Dispatch, July 14, 1881, 1; “The Heat," St. Louis Post-Dispatch, July 15, 1881, 4; “The Weather,” St. Louis Post-Dispatch, July 22, 1881, 8; 
death, but he did believe that he contributed to it, stating that the medicine's "administration may have hastened his death." It is notable that MacBride never called Baurichter "doctor" in his inquest because of his lack of formal training — a similarity to physicians who performed abortions discussed in Chapter Three. ${ }^{230}$

Like the deaths caused by abortions performed by physicians, the press wrote about Anderson's death because of the potential malpractice. Although reporters often ignored the deaths of African Americans, the possibility that a local doctor may have committed a crime evidently sparked their interest in Anderson's death. The St. Louis Globe-Democrat ran the headline, "Alleged Case of Malpractice," which summed up the piece. The article alluded to Anderson's case of syphilis in saying that he sought treatment for a "constitutional private disease." The reporter detailed the medicines that Baurichter gave to Anderson and said little about Anderson himself—only that he was a negro who was found dead in bed recently and had had to stop working because of illness. The reporter seemed to be most interested in whether or not Baurichter would face charges, but, ultimately, he did not. Both the coroner and the press seemed more concerned about potential malpractice than the deceased and were likely policing the medical profession rather than seeking justice for Anderson. None sought to determine why Anderson sought the aid of Baurichter, which was probably because as a black man, he had few options for medical care. ${ }^{231}$

${ }^{230}$ Frank Anderson Inquest, October 25 and 26, 1880, Case No. 2356, Folder 37, Box 24 (Missouri State Archives microfilm roll C31277), St. Louis City Office of the Coroner-Inquests 18451900, Missouri State Archives, Jefferson City, Missouri.

231 "Coroner's Cases," St. Louis Globe-Democrat, Tuesday, October 26, 1880, 4; Because his acts "may have" accelerated Anderson's death, Baurichter did not face charges. Newspaper accounts (or lack thereof) confirm this and he never spent time in the penitentiary. Considering some people whom coroners and their juries did hold responsible for the deaths of others often faced no charges, this is not surprising. 
The death of Valentine Grajek may have also stemmed from malpractice, but unlike in Anderson's death, Deputy Coroner George Peck concluded that only "congestion of the brain" killed the thirty-year-old German man. Grajek was a patient at the city's Insane Asylum when he died on September 13, 1883, so Peck interviewed four witnesses and ordered an autopsy to determine how Grajek had died. Not only did Grajek die in a public place, but the asylum staff had restrained him and forced a rubber tube into his mouth (and probably down his throat) to administer medicine right before he died. Dr. Howard, the superintendent, told Peck that the restraints were standard for patients who assaulted asylum staff, as Grajek allegedly had, as was using a rubber tube to force medication for patients who resisted it. Grajek seemed fine that evening after the incident, but after 10:00 that night an attendant found him dead, with a "white frothy foam" coming from his nose and mouth. Dr. Howard was sure that the druggist had not made a mistake with the prescription, he told the coroner. Peck ordered an autopsy, and Dr. Walfera concluded that Grajek had died from "congestion of the brain." Two other physicians who assisted with the autopsy rendered the same conclusion. Peck rendered a verdict of "congestion of the brain" based on that information. The press barely even reported on Grajek's death, probably because he was a patient in the Insane Asylum, and only reported that he had died in the institution, with no clues as to his cause of death. In this case, it is possible that Peck did not decide that treating physicians or the asylum druggist contributed to Grajek's death because they were licensed, well-educated physicians - unlike Baurichter. Still, it is possible that the medication and/or trauma from the struggle with asylum staff exacerbated any existing health conditions that 
Grajek had - particularly since the autopsy found that all organs except for Grajek's froth-filled lungs were healthy. ${ }^{232}$

The possibility that someone else caused or contributed to a natural death was even stronger in the death of Kate Williamson, the death discussed in the opening story. In fact, George Peck initially suspected injuries caused by an assault from her lover, Billy McCue, caused her death between the hours of 3:00 and 6:00 am on September 15, 1880. Unlike in most cases of natural deaths, Peck believed that Williamson's death was a homicide and investigated it as such, interviewing seven witnesses and ordering an autopsy. Police also arrested William "Billy" McCue because they suspected that he had inflicted deadly injuries upon her that night. Peck spoke with Williamson's relatives, neighbors, and friends and also ordered Dr. James C. Nidelet to perform a postmortem exam on her body. When Peck examined her body, he found no marks upon her, but Williamson's friends detailed a fight that she had had with McCue the night before. McCue, her lover, had shoved her, punched her, and even pulled an earring from her ear and broke it. He later broke into her room that night after they fought, likely while he was intoxicated. Williamson called the police once that night, but they would not arrest McCue unless she pressed charges, which she refused to do. Police arrested McCue when friends found Williamson dead the next morning, however. ${ }^{233}$

McCue expressed sadness and surprise that Williamson had died overnight, even commenting that there were no marks upon her body, as if he believed that meant that he

\footnotetext{
${ }^{232}$ Valentine Grajek Inquest, September 13, 1883, Case No. 404, Folder 55, Box 35 (Missouri State Archives microfilm roll C31280), St. Louis City Office of the Coroner-Inquests 1845-1900, Missouri State Archives, Jefferson City, Missouri; "Yesterday's Death List," St. Louis Globe-Democrat, Saturday, September 15, 1883, 11.

${ }^{233}$ Kate Williamson Inquest, September 15, 1880, Case No. 408, Folder 59, Box 35 (Missouri State Archives microfilm roll C31280), St. Louis City Office of the Coroner-Inquests 1845-1900, Missouri State Archives, Jefferson City, Missouri.
} 
could not have beaten her to death. ${ }^{234}$ His tears were probably for himself, not Williamson, as he also expressed concern over facing execution by hanging for her death. Deputy Coroner Peck was less certain that McCue killed Williamson than were her friends, however, because the results from Dr. Nidelet's autopsy did not find evidence that McCue's attack had killed Williamson. Instead, he found that both her heart and lungs were congested and he concluded that these illnesses were "evidently the result of alcoholism." It is uncertain why he believed that Williamson was an alcoholic because her friends testified that she drank only beer and believed that she was not a heavy drinker, commenting that she drank as much as "all hard working women do." She was rather young, at thirty-eight, but her sister-in-law testified that she had some "indications of heart disease" at age thirty-six, so she had a history of a heart condition. Perhaps Nidelet made assumptions about her lifestyle because she was a working-class woman who worked as a washerwoman, had friends and neighbors who were African American, lived in a tenement, and was in a relationship with a rough man — one who often stayed overnight. ${ }^{235}$ Nidelet likely sought to explain why she suddenly died and what caused the congestion, but Peck evidently disagreed with Nidelet because despite the autopsy results, he rendered her death as caused by "congestive heart and lung failure" with "fluid buildup, perhaps from heart disease" with no mention of alcoholism. Once the inquest concluded, police released McCue. ${ }^{236}$

${ }^{234}$ Williamson Inquest. He intentionally assaulted her in ways that would not leave bruises or other marks, he told one of her friends as he was attacking Williamson.

${ }^{235}$ James C. Nidelet also concluded that Matilda Reynolds died from alcoholism and, while she did drink heavily on a regular basis, toxicology analysis determined that she died from arsenic poisoning. His brother, Coroner Sylvester Nidelet, ordered that toxicology analysis.

${ }^{236}$ Williamson Inquest; "Was it Murder?," St. Louis Post-Dispatch, September 14, 1883, 2; "The Williamson Inquest," St. Louis Post-Dispatch, September 15, 1883, 4; “A Suspicious Case," St. Louis Globe-Democrat, September 15, 1883, 12; "Died," St. Louis Globe-Democrat, Sunday, September 16, 
The St. Louis press covered Kate Williamson's inquest because it was initially a suspected murder. Reporters for the Post-Dispatch and Globe-Democrat and wrote about the suspicious circumstances surrounding Williamson's death, McCue's assault on her, and some details of McCue's reaction. A Post-Dipsatch reporter noted that "the police say that he has a bad reputation" and claimed that "Red" McCue was "shaken out of an apparent stupor" by police who told him of his lover's death—and then arrested him. The Globe-Democrat also published a lengthy account detailing the couple's quarrels and noting McCue's arrest. Once the inquest concluded, both papers printed much shorter articles that noted the verdict and McCue's release from custody. The Post-Dispatch reported only the verdict, while the Globe-Democrat added information from the autopsy - that the cause of death was alcoholism. ${ }^{237}$

While the lengthy inquest into Kate Williamson's death and initial suspicion of homicide was unusual for deaths caused by disease or illness, the complicated nature of her death was not. Despite brief investigations and verdicts that determined that the men and women in this chapter died from natural causes, some may have died at the hands of others - at least in part. In other cases, these men and women may have died from illnesses that the coroners did not acknowledge in their verdicts. Coroners may not have felt the need to determine an accurate time of death or pinpoint a specific illness with certainty because these men and women died from sicknesses, not homicides. Their verdicts would not implicate or exonerate anyone in most cases. While it was the job of

1883, 8; "Released from Custody," in "Multiple News Items," St. Louis Globe-Democrat, Sunday, September 16, 1883, 16; "City News," St. Louis Post-Dispatch, September 17, 1883, 8.

237 "Was it Murder?," St. Louis Post-Dispatch, September 14, 1883, 2; Released from Custody," in "Multiple News Items," St. Louis Globe-Democrat, Sunday, September 16, 1883, 16. 
the coroner to determine an accurate cause of death, evidently, they felt that their duty was less pressing in these cases. Nonetheless, witness testimony reveals that these natural deaths were more complicated than their investigations and verdicts made them appear. 


\section{Conclusion}

Despite their medical training and experience as physicians, St. Louis coroners based their death investigations and verdicts on their own assumptions as well as their professional knowledge and standards. Coroners in St. Louis were far better trained than Missouri law required, but they were still human beings and shaped by their own belief systems. When it came to investigating and rendering a verdict in a sudden, suspicious, or unattended death, these men relied on their assumptions about the reputation, race, class, and gender of the deceased as much as the circumstances surrounding their deaths. Coroners were supposed to work to determine how a person came to his or her death and if anyone else was responsible for that death, but, in some cases, they went beyond their duties to also understand why a person died, particularly in deaths by suicide for men and women whom they understood to be respectable. In other cases, however, such as in natural deaths and deaths of men and women who had questionable or bad reputations, coroners did not even always work to determine an accurate cause of death. Family relationships mattered, too, and men and women who had family members to testify before the coroner were more likely to receive verdicts of insanity than were their more isolated counterparts. In a few cases, coroners even rendered verdicts of accidental deaths despite evidence of suicide because of the testimony of family members. Training and experience as physicians was important, but other factors shaped coroners' investigations just as much.

Missouri coroners faced criticism in the late nineteenth and early twentieth centuries for performing flawed investigations, but primarily because of their lack of training. While deputy coroners in St. Louis often lacked medical training, their 
supervising coroners did not. While some critics called for a new medical examiner's office instead of a coroner's office, St. Louis maintained its system until the 1970s, when it became the Office of the Medical Examiner. Missouri still has a coroner system throughout much of the state and in some counties, office holders have little medical training or experience. It was not an absence of training or skill that prompted St. Louis coroners to render some inaccurate verdicts between 1875 and 1885, however, but their belief systems and the testimony that they had from family members. ${ }^{238}$

Death is still political as are death investigations. Instead of reading sensationalistic stories of suicides and deaths from alcohol or drugs, newspapers often conceal these deaths by using phrases such as "died unexpectedly" or "died at home." Family members write these obituaries and it is noteworthy when they openly discuss that their loved one died by suicide or an addiction. In some ways, these deaths are more stigmatized today than they were in the late nineteenth century.

Many of the problems explored in this study still exist. News outlets today discuss a "suicide epidemic," particularly among middle-aged white men as well as war veterans and physicians and psychologists are searching for solutions to those problems. The United States is also in the midst of an "opioid crisis" because of prescription painkillers and heroin, rather than the morphine, laudanum, and opium that were more commonly used in the late nineteenth century. Alcoholism, while not deemed a public health crisis, still harms a number of people and families. And while it is easier for

${ }^{238}$ R.B.H. Gradwohl, "The Office of the Coroner: Its past, its Present, and its Advisability of its Abolishment in the Commonwealth of Missouri," Journal of the American Medical Association Vol. LIV (March 12, 1910): 842-846; John M. McIlroy, Jr., "The Coroner v. The Medical Examiner in Missouri," Missouri Law Review 34, no. 2 (1969): 219-235; Missouri Coroners' and Medical Examiners' Association, http://www.mcmea.org/index.html; Office of the Medical Examiner, http://www.stlouisco.com/HealthandWellness/MedicalExaminer. 
women to seek treatment for alcoholism today, there is still a chapter "for the wives" in The "Big Book," the guidebook for the popular twelve-step program Alcoholics Anonymous. Women also still struggle to find safe, accessible abortions despite the nationwide legalization of abortion in 1973 . The procedure has recently become more difficult to access, particularly for the working class and poor, just as it was a century before. Just as they did in the 1870 s and 1880 s, anti-abortion activists continue to treat women as the hapless victims of abortion providers. Finally, domestic violence, murdersuicides, and homicides in general are still national problems, although today there is more focus on mass shootings than the more common violence that occurs between people who know each other. Some point out that there is a connection between domestic violence and mass shootings, however, as these perpetrators often have a history of beating their wives and girlfriends. Finally, activists point out the disproportionate number of African American men and women killed by police—often when unarmed and during routine traffic stops. Police violence against African Americans is not new, nor is racism, as apparent in the coroners' inquests into the deaths of black men and women. But the attention to this problem is new. Violence and early deaths continue to be problems for individuals, their families, and society in general. It is important to understand the histories of women like Catherina Leilich, who tucked in her young son before throwing herself into a well, or Lillie Colcord, who was killed by her husband, Josiah, before he took his own life. Their stories, while more than a hundred years old, help illuminate present-day problems and, hopefully, can help create solutions. ${ }^{239}$

${ }^{239}$ Alcoholics Anonymous, Fourth edition (Alcoholics Anonymous World Services, Inc., 2002). 
Table One: Data Analyzed by Chapter

\begin{tabular}{|c|c|c|c|c|c|c|}
\hline Verdict & Chapter & $\begin{array}{l}\text { Total } \\
\text { Deaths }\end{array}$ & $\begin{array}{l}\text { Sex } \\
\text { Ratio }\end{array}$ & $\begin{array}{l}\text { Age } \\
\text { Range }\end{array}$ & $\begin{array}{l}\text { Civil } \\
\text { Status }\end{array}$ & Race/Ethnicity \\
\hline Deaths by suicide & One & 29 & $\begin{array}{c}10 \\
\text { women } \\
19 \text { men }\end{array}$ & $20-50$ & $\begin{array}{c}18 \\
\text { married (2 } \\
\text { separated) } \\
2 \text { divorced } \\
6 \text { single } \\
2 \\
\text { widowed }\end{array}$ & $\begin{array}{c}10 \text { German } \\
10 \text { native-born } \\
\text { white } \\
2 \text { Bohemian } \\
2 \text { Canadian } \\
2 \text { English } \\
1 \text { African- } \\
\text { American } \\
1 \text { Swiss } \\
1 \text { unknown }\end{array}$ \\
\hline $\begin{array}{l}\text { Suicide by } \\
\text { Insanity/Temporary } \\
\text { Insanity }\end{array}$ & One & 18 & & & & \\
\hline $\begin{array}{l}\text { Alcohol-Related } \\
\text { Deaths (all feature } \\
\text { the word "alcohol" } \\
\text { in the verdict) }\end{array}$ & Two & 18 & $\begin{array}{c}10 \\
\text { women } \\
8 \text { men }\end{array}$ & $25-46$ & $\begin{array}{c}10 \\
\text { married } \\
4 \text { single } \\
4 \\
\text { widowed }\end{array}$ & $\begin{array}{c}10 \text { native-born } \\
\text { white } \\
4 \text { Irish } \\
2 \text { African- } \\
\text { American } \\
2 \text { German }\end{array}$ \\
\hline $\begin{array}{l}\text { Deaths from } \\
\text { complications from } \\
\text { abortions }\end{array}$ & Three & 4 & $\begin{array}{c}4 \\
\text { women }\end{array}$ & $25-30$ & $\begin{array}{l}3 \text { married } \\
(2 \\
\text { married, } \\
\text { but } \\
\text { separate }) \\
1 \\
\text { widowed }\end{array}$ & $\begin{array}{c}3 \text { native-born } \\
\text { white } \\
1 \text { Irish }\end{array}$ \\
\hline $\begin{array}{l}\text { Deaths from } \\
\text { homicide }\end{array}$ & Four & 15 & $\begin{array}{c}12 \text { men } \\
3 \\
\text { women }\end{array}$ & $20-50$ & $\begin{array}{l}8 \text { married } \\
4 \text { single } \\
2 \\
\text { widowed }\end{array}$ & $\begin{array}{c}4 \text { African- } \\
\text { American } \\
2 \text { native-born } \\
\text { white } \\
2 \text { German } \\
1 \text { Polish and } \\
\text { Jewish } \\
1 \text { Canadian } \\
1 \text { English } \\
1 \text { Irish } \\
1 \text { unknown }\end{array}$ \\
\hline
\end{tabular}




\begin{tabular}{|c|c|c|c|c|c|c|}
\hline $\begin{array}{l}\text { Deaths from } \\
\text { accidents }\end{array}$ & Five & 33 & $\begin{array}{c}23 \text { men } \\
10 \\
\text { women }\end{array}$ & $13-50$ & $\begin{array}{c}19 \\
\text { married } \\
12 \text { single } \\
2 \\
\text { widowed }\end{array}$ & $\begin{array}{c}11 \text { German } \\
8 \text { African- } \\
\text { American } \\
\text { Native-born } \\
\text { white } \\
5 \text { Irish } \\
1 \text { French } \\
1 \text { Italian } \\
1 \text { unknown }\end{array}$ \\
\hline $\begin{array}{l}\text { Deaths from } \\
\text { natural causes } \\
\text { (illness or disease) }\end{array}$ & Six & 14 & $\begin{array}{c}7 \\
\text { women } \\
7 \text { men }\end{array}$ & $30-47$ & $\begin{array}{l}6 \text { married } \\
5 \text { single } \\
3 \\
\text { widowed }\end{array}$ & $\begin{array}{c}5 \text { African- } \\
\text { American } \\
3 \text { native-born } \\
\text { white } \\
2 \text { Irish } \\
1 \text { German } \\
1 \text { Polish } \\
1 \text { Swiss } \\
1 \text { Welsh }\end{array}$ \\
\hline
\end{tabular}


Figure One: Map of St. Louis, 1901

Verso: Map of Kansas City, "Map of St. Louis 1901," The State Historical Society of Missouri, http://digital.shsmo.org/cdm/singleitem/collection/Maps/id/15/rec/5 [accessed April 12, 2018].

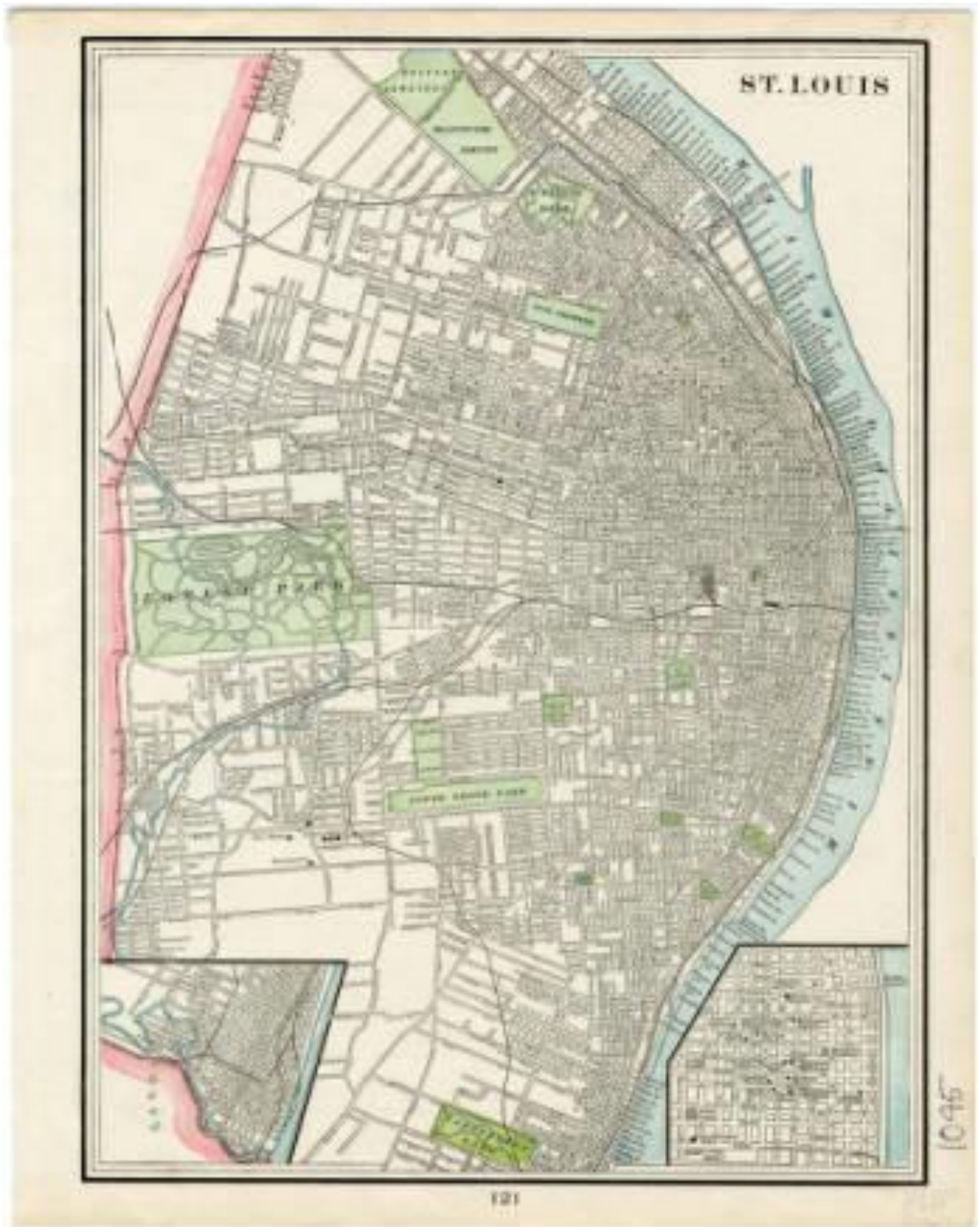




\section{Bibliography}

Primary Sources-Published

Articles

Bacon, C. S. "The Duty of the Medical Profession in Relation to Criminal Abortion," Illinois Medical Journal 7 (1905): 18-24.

Berger, J. “A Fatal Fashion,” St. Louis Medical Journal 12, no. 7 (July 1885): 289-96.

Burdett, Everett W. "The Medical Jurisprudence of Criminal Abortion," New England Medical Gazette 18 (July 1883): 200-214.

"Criminal Abortion in Its Broadest Sese," Journal of the American Medical Association 51, no. 12 (September 19, 1908): 957-61.

Decaisne, Dr. E. “Dipsomania in Women," The Quarterly Journal of Inebriety 11 (1889): 247-252.

"Dipsomania," in "Clinical Notes and Comments," The Quarterly Journal of Inebriety 4, no. 1 (Jan. 1880): 51-52.

"Dipsomania and Heredity" in "Clinical Notes and Comments," The Quarterly Journal of Inebriety 10 (1888): 395-397.

Dixon-Jones, Mary A. "Criminal Abortion: Its Evil and Sad Consequences," Medical Record 46 (July 7, 1894): 9-16.

Ely, William B. "The Ethics of Criminal Abortion,” Western Medical Review 10, no. 3 (March 1905): 97-102.

Fisher, T.W., M.D., "Insane Drunkards—Their Medico-Legal Relations," in "Clinical Notes and Comments," The Quarterly Journal of Inebriety 4, no. 1 (Jan. 1880): 18.

Goldstein, Max Aaron, editor, One Hundred Years of Medicine and Surgery in Missouri: Historical and Biographical Review of the Physicians and Surgeons of the State of Missouri and Sketches of Some of Its Notable Medical Institutions. St. Louis: St. Louis Star, 1900.

Gradwohl, R.B.H. "The Office of the Coroner: Its past, its Present, and its Advisability of its Abolishment in the Commonwealth of Missouri." Journal of the American Medical Association Vol. LIV (March 12, 1910): 842-846. 
Gross, Charles. "The Early History and Influence of the Office of Coroner." Political Science Quarterly 7 (1892): 656-672.

Kerr, Norman, M.D., F.L.S., "The Treatment of Female Inebriety," "Dipsomania and Heredity" in "Clinical Notes and Comments," The Quarterly Journal of Inebriety 10 (1888): 68-76.

The Mayor's Message with Accompanying Documents, to the Municipal Assembly of the City of St. Louis, for the Fiscal Year Ending April 12 ${ }^{\text {th }}, 1897$, Printed for the Municipal Assembly, 1898.

Pringle, Robert, M.D., Surgeon-Major, "Homicidal and Suicidal Inebriety," The Quarterly Journal of Inebriety 9 (1887): 156-164.

"Race Suicide (Criminal Abortion)," in "Correspondence," Journal of the American Medical Association 46, no. 13 (March 31, 1906): 972.

Schultz, Oscar T. and E.M. Morgan. "The Coroner and the Medical Examiner." in Bulletin of the National Research Council Nos. 64-66. Washington, D.C.: July, 1928.

Spivy, Raymond M. "The Control and Treatment of Criminal Abortion," Journal of the Missouri State Medical Association 15, no. 1 (January 1918): 1-5.

$\underline{\text { Books }}$

Alcoholics Anonymous, Fourth edition. Alcoholics Anonymous World Services, Inc., 2002.

Beck, Theodoric Romeyn Beck, M.D., L.L.D. and Beck, John B., M.D. Elements of Medical Jurisprudence, $12^{\text {th }}$ ed., with notes by an association of the friends of Drs. Beck; the whole revised by C.R. Gilman. Philadelphia: J.B. Lippincott \& Co., 1863.

Dacus, Joseph A. and James W. Buel. A Tour of St. Louis: or, The Inside Life of a Great City. St. Louis, Missouri: Western Publishing Co., 1878.

Directory of Physicians, Dentists and Druggists of Missouri, 1889 (St. Louis: G. Gonser \& Co., 1889).

Durkheim, Emile. Suicide: A Study in Sociology. 1897. Reprint. Translated by John A. Spaulding and George Simpson. New York: The Free Press, 1951.

Gould's St. Louis Directory. St. Louis: Gould Directory Co., 1874, 1880, 1881, 1889, 1892, 1897, 1898. 
Guernsey, R.S. Suicide: History of the Penal Laws Relating to it in Their Legal, Social, Moral, and Religious Aspects, in Ancient and Modern Times. New York: L.K. Strouse \& Co., 1883.

Journal of the Missouri State Medical Association. St. Louis: Missouri State Medical Association, 1904-1952.

Morselli, Henry. Suicide: An Essay on Comparative Moral Statistics. 1882. Reprint. New York: Arno Press, 1975.

Simpson, Keith, ed. Taylor's Principles and Practice of Medical Jurisprudence. 1865. Reprint, $12^{\text {th }}$ ed., Boston: Little, Brown and Company, 1965.

Winslow, Forbes. The Anatomy of Suicide. London: Henry Renshaw, 1840.

$\underline{\text { Newspapers }}$

The Cleveland Herald

Daily Evening Bulletin (San Francisco, California)

Daily Rocky Mountain News

Inter Ocean

Milwaukee Sentinel

New York Times

Potosi Journal

St. Louis Globe-Democrat

St. Louis Post-Dispatch

$\underline{\text { Pamphlets }}$

Allen, Dr. B.J. Physician's Report of the St. Vincent's Institution for the Insane, for the Years 1862 and 1863. St. Louis: 1864.

Primary Sources-Unpublished 
FindAGrave. Accessed online: www.findagrave.com.

Papers, Johnson, Charles P. (1836-1920), (Collection CA6380). The State Historical Society of Missouri, University of Missouri, Columbia, Missouri.

\section{Government Documents and Official Records}

Ancestry.com. Missouri Death Records, 1834-1910. Accessed online: ancestry.com.

Ancestry.com. Missouri Marriage Records, 1805-2002. Accessed online: ancestry.com.

Ancestry.com. St. Louis City Wills. Accessed online: ancestry.com.

General Statutes of the State of Missouri. Jefferson City: Emory S. Foster, 1866.

"Historical Census Browser." University of Virginia Library. http://mapserver.lib.virginia.edu/php/county.php [accessed June 15, 2011].

Journal of the Missouri House, Fourteenth General Assembly, First Session, 1846, p. 416, General Assembly, Record Group 550, Missouri State Archives, Jefferson City.

Laws of Missouri, General Assembly Twenty-Eight, Regular Session, 1875, p. 99, State Documents Collections, Missouri State Archives, Jefferson City.

Missouri Death Certificates. Missouri State Archives, Jefferson City, Missouri. Accessed online:

http://www.sos.mo.gov/archives/resources/deathcertificates/default.asp.

Missouri Secretary of State. Coroner's Inquest Database. Accessed online: http://www.sos.mo.gov/archives/resources/coroners/ [accessed September 1, 2017].

Missouri Secretary of State. Missouri State Penitentiary Database. Accessed online: http://s1.sos.mo.gov/records/archives/archivesdb/msp/Detail.aspx?id=35156। [accessed December 20, 2016].

Revised Statutes of the State of Missouri. St. Louis: J. W. Dougherty, 1845.

Revised Statutes of the State of Missouri. Jefferson City: Carter and Regan, 1879.

Revised Statutes of the State of Missouri. Jefferson City: Tribune Printing Co., 1889.

St. Louis City Office of the Coroner-Inquests, 1845-1900, St. Louis, Missouri, Missouri State Archives, Jefferson City, Missouri. 
St. Louis City Circuit Court, Criminal Court Record Book 19.

St. Louis City Circuit Court, Criminal Court Record Book 20.

St. Louis City Wills, St. Louis, Missouri, Vol. K2, p. 539, SLCL film CIWI-15, FHL film 1405582.

Statutes of the State of Missouri, 3rd ed. St. Louis: W.J. Gilbert, 1872.

United States Bureau of the Census, Records for Missouri, 1850, 1860, 1870, 1880, 1900, 1910.

United States Bureau of the Census, Records for Illinois, 1870, 1880.

United States Bureau of the Census, Records for Kentucky, 1850, 1870, 1880.

Secondary Sources-Published

$\underline{\text { Articles }}$

Adler, Jeffrey S. “'I Loved Joe, But I Had to Shoot Him’: Homicide by Women in Turnof-the- Century Chicago." The Journal of Criminal Law and Criminology 92, no. 3/4 (Spring-Summer, 2002): 867-898.

. "If We Can't Live in Peace, We Might as Well Die": Homicide-Suicide in Chicago, 1875-1910. Journal of Urban History 26, no. 3 (Nov. 1999): 3-21

. “'We've Got a Right to Fight; We're Married': Domestic Homicide in Chicago, 1875-1920." The Journal of Interdisciplinary History 34, no. 1 (Summer, 2003): 27-48.

Atkinson, J. Maxwell. "Societal Reactions to Suicide: the Role of Coroners' Definitions." in Images of Deviance, ed. Stanley Cohen. Middlesex, England: Penguin Books, 1971.

Berry, Stephen. "The Historian as Death Investigator," in Weirding the War: Stories from the Civil War's Ragged Edges, Stephen Berry, ed. (Athens: University of Georgia, 2011): 176-188.

Brancaccio, Maria Teresa, Eric J. Engstrom, and David Lederer. "The Politics of Suicide: Historical Perspectives on Suicidology before Durkheim. An Introduction." Journal of Social History 46, no. 3 (2013): 607-619. 
Breyfogle, Herbert S. "The Laws of Missouri Relating to Inquests and Coroners." Missouri Law Review 10 (1945): 34-63.

Haag, Pamela. “The 'Ill-Use of a Wife:' Patterns of Working-Class Violence in Domestic and Public New York City, 1860-1880.” Journal of Social History 25, no. 3 (Spring, 1992): 447-477.

Hanzlick, MD, Randy and Combs, MPH, Debra. "Medical Examiner and Coroner Systems: History and Trends." Journal of the American Medical Association 279, no. 11 (March 18, 1998): 870-874.

Higginbotham, Evelyn Brooks. "The Politics of Respectability" in Righteous Discontent: The Women's Movement in the Black Baptist Church, 1880-1920. Cambridge and London: Harvard University Press, 1993.

Johnstone, Gerry. "From Vice to Disease? The Concepts of Dipsomania and Inebriety, 1860-1908." Social and Legal Studies 5 (1996): 37-56.

Kudlick, Catherine J. "Disability History: Why We Need Another 'Other." The American Historical Review, 108, no. 3 (June 2003): 763-793.

Kushner, Howard I. "Biochemistry, Suicide, and History: Possibilities and Problems." The Journal of Interdisciplinary History 16, no. 1 (Summer, 1985): 69-85. . "Immigrant Suicide in the United States: Toward a Psycho-Social History." The Journal of Social History 18, no. 1 (Fall, 1984): 3-24.

. "Suicide, Gender, and the Fear of Modernity in Nineteenth-Century Medical and Social Thought." Journal of Social History 26, no. 3 (Spring, 1993): 461-490.

. "Taking Biology Seriously: The Next Task for Historians of Addiction?" Bulletin of the History of Medicine 80, no. 1 (Spring 2006): 115-143.

"Women and Suicide in Historical Perspective." Signs 10, no. 3 (Spring, 1985): 537-552.

Langer, Susanne, Jonathan Scourfield and Ben Fincham. "Documenting the Quick and the Dead: a Study of Suicide Case Files in a Coroner's Office." The Sociological Review 56, no. 2 (2008): 293-308.

Laragy, Georgina. “'A Peculiar Species of Felony': Suicide, Medicine, and the Law in Victorian Britain and Ireland." Journal of Social History 46, no. 3 (2013): 732743. 
Lehmann, Jennifer M. "Durkheim's Response to Feminism: Prescriptions for Women." Sociological Theory 8, no. 2 (Autumn, 1990): 163-187.

. "Durkheim's Theories of Deviance and Suicide: A Feminist Reconsideration." American Journal of Sociology 100, no. 4 (Jan., 1995): 904930.

Lender, Mark. "A Special Stigma: Women and Alcoholism in the Late $19^{\text {th }}$ and Early $20^{\text {th }}$ Centuries," in Alcohol Interventions: Historical and Sociocultural Approaches, eds. David L. Strug, S. Priyadarsini, and Merton M. Hyman. New York: The Haworth Press, 1986, 41-57.

Levine, Harry Gene, "The Discovery of Addiction: Changing Conceptions of Habitual Drunkenness in America," Journal of Studies on Alcohol 39, no. 1 (1978): 143174.

Jansson, Asa. "From Statistics to Diagnostics: Medical Certificates, Melancholia, and 'Suicidal Propensities' in Victorian Psychiatry." Journal of Social History 46, no. 3 (2013): 716-731.

Marsh, Ian. "The Uses of History in the Unmaking of Modern Suicide." Journal of Social History 46, no. 3 (2013): 744-756.

McIlroy, Jr., John M. “The Coroner v. The Medical Examiner in Missouri.” Missouri Law Review 34, no. 2 (1969): 219-235.

Prestwich, Patricia E. "Female Alcoholism in Paris, 1870-1920: The Response of Psychiatrists and of Families," History of Psychiatry 14, no. 3 (2003): 321-336.

Reagan, Leslie J. ““About to Meet Her Maker’: Women, Doctors, Dying Declarations, and the State's Investigation of Abortion, Chicago, 1867-1940." The Journal of American History 77, no. 4 (Mar., 1991): 1240-1264.

Snyder, Terri L. "Suicide, Slavery, and Memory in North America." The Journal of American History 97, no. 1 (June 2010): 39-62.

Snyder, Terri L. "What Historians Talk About When They Talk About Suicide: The View from Early Modern British North America." History Compass 5, no. 2 (2007): 658-674.

Swingle, H. Morley. "Coroner's Inquests in Missouri: Modern Usage of the Hue and Cry." Journal of the Missouri Bar 63, no. 2 (March-April, 2007). http://www.mobar.org/284a1e15-4298-418a-8a06-97cdfa2e39e7.aspx (accessed 11 August 2011).

$\underline{\text { Books }}$ 
Adler, Jeffrey. First in Violence, Deepest in Dirt: Homicide in Chicago, 1875-1920. Cambridge: Harvard University Press, 2002.

Atkinson, J. Maxwell. Discovering Suicide: Studies in the Social Organization of Sudden Death. Pittsburgh: University of Pittsburgh Press, 1978.

Brodie, Janet Farrell. Contraception and Abortion in Nineteenth-Century America (Ithaca, NY: Cornell University Press, 1994.

Cooter, Roger and Bill Luckin, eds. Accidents in History: Injuries Fatalities and Social Relations. Amsterdam: Editions Rodopi B.V., 1997.

Corbett, Katharine T. In Her Place: a Guide to St. Louis Women's History. St. Louis: Missouri Historical Press, 1999.

Dubow, Sara. Ourselves Unborn: A History of the Fetus in Modern America. New York: Oxford University Press, 2011.

Friend, Craig Thompson and Lorri Glover. Death and the American South. New York: Cambridge University Press, 2014.

Gamber, Wendy. The Boardinghouse in Nineteenth-Century America. Baltimore: Johns Hopkins University Press, 2007.

Gersuny, Carl. Work Hazards and Industrial Conflict. Hanover, N.H.: University Press of New England, 1981.

Gilfoyle, Timothy J. City of Eros: New York City, Prostitution, and the Commercialization of Sex, 1790-1920. New York and London: W.W. Norton \& Company, 1992.

Gordon, Linda. Heroes of Their Own Lives: The Politics and History of Family Violence: Boston, 1880-1960. New York: Viking, 1988.

Hecht, Jennifer Michael. Stay: A History of Suicide and the Philosophies Against It. New Haven: Yale University Press, 2013.

Holmes, Ronald M. and Stephen T. Suicide: Theory, Practice, and Investigation. Thousand Oaks, CA: SAGE Publications, 2005.

Jamison, Kay Redfield. Night Falls Fast: Understanding Suicide. New York: Alfred A. Knopf, 1999.

Jentzen, Jeffrey M. Death Investigation in America: Coroners, Medical Examiners, and 
the Pursuit of Medical Certainty. Cambridge, Mass.: Harvard University Press, 2009.

Kushner, Howard I. American Suicide: a Psychocultural Exploration. New Brunswick: Rutgers University Press, 1991.

Lane, Roger Violent Death in the City: Suicide, Accident, and Murder in Nineteenth Century Philadelphia (Cambridge: Harvard University Press, 1979).

Laqueur, Thomas W. The Work of the Dead: A Cultural History of Mortal Remains. Princeton, New Jersey: Princeton University Press, 2015.

Longmore, Paul K. and Lauri Umansky. The New Disability History: American Perspectives. New York : New York University Press, 2001.

Luker, Kristin. Abortion and the Politics of Motherhood. Berkeley: University of California Press, 1984.

Martin, Scott C. Devil of the Domestic Sphere: Temperance, Gender, and Middle-class Ideology, 1800-1860. DeKalb: Northern Illinois University Press, 2008.

McGoff-McCann, Michelle. Melancholy Madness: A Coroner's Casebook. Douglas Village, Cork: Mercier Press, 2003.

Minois, Georges. History of Suicide: Voluntary Death in Western Culture. Translated by Lydia G. Cochrane. Baltimore: The Johns Hopkins University Press, 1999.

Mintz, Steven and Susan Kellogg. Domestic Revolutions: A Social History of American Family Life. New York: The Free Press, 1988.

Mohr, James C. Doctors and the Law: Medical Jurisprudence in Nineteenth-Century America. New York: Oxford University Press, 1993. Abortion in America: The Origins and Evolution of National Policy, 1800 1900. New York: Oxford University Press, 1978).

Mumford, Kevin. InterZones: Black/White Sex Districts in Chicago and New York in the early Twentieth Century. New York: Columbia University Press, 1997.

Murdock, Catherine Gilbert. Domesticating Drink: Women, Men, and Alcohol in America: 1870-1940. Baltimore and London: The Johns Hopkins University Press, 1998.

Neff, John R. Honoring the Civil War Dead: Commemoration and the Problem of Reconciliation. Lawrence: University Press of Kansas, 2005. 
Nielsen, Kim E. Beyond The Miracle Worker: The Remarkable Life of Annie Sullivan Macie and Her Extraordinary Friendship with Helen Keller. Boston: Beacon Press, 2009.

. A Disability History of the United States: Revisioning American History. Boston: Beacon Press, 2012.

Petchesky, Rosalind Pollack. Abortion and Woman's Choice: The State, Sexuality, and Reproductive Freedom. New York: Longman, 1984.

Pickering, W.S.F. and Geoffrey Walford, eds. Durkheim's Suicide: A Century of Research and Debate. London and New York: Routledge, 2000.

Pleck, Elizabeth. Domestic Tyranny: The Making of Social Policy Against Family Violence from Colonial Times to the Present. New York: Oxford University Press, 1987.

Rambo, Kirsten S. "Trivial Complaints:" The Role of Privacy in Domestic Violence Law and Activism in the U.S. New York: Columbia University Press, 2009.

Reagan, Leslie J. When Abortion was a Crime: Women, Medicine, and Law in the United States, 1867-1973. Berkeley: University of California Press, 1997.

Rogers, Donald W. Making Capitalism Safe: Work Safety and Health Regulation in America, 1880-1940 (Urbana: University of Illinois Press, 2009.

Rorabaugh, William J. The Alcoholic Republic: An American Tradition. New York: Oxford University Press, 1979.

Rosen, Ruth. The Lost Sisterhood: Prostitution in America, 1900-1918. Baltimore and London: The Johns Hopkins University Press, 1982.

Roth, Randolph. American Homicide. Cambridge: Belknap press of Harvard University Press, 2009.

Rothman, David J. Conscience and Convenience: the Asylum and Its Alternatives in Progressive America. Rev. ed. New York: Aldine de Gruyter, 1980.

Silkenat, David. Moments of Despair: Suicide, Divorce, and Debt in Civil War Era North Carolina. Chapel Hill: The University of North Carolina Press, 2011.

Snyder, Terri. The Power to Die: Slavery and Suicide in British North America. Chicago: The University of Chicago Press, 2015.

Rickie Solinger, Pregnancy and Power: A Short History of Reproductive Politics in 
America. New York: New York University Press, 2005.

Srebnick, Amy Gilman. The Mysterious Death of Mary Rogers: Sex and Culture in Nineteenth-Century New York. New York and Oxford: Oxford University Press, 1995.

Srole, Carole. Transcribing Class and Gender: Masculinity and Femininity in Nineteenth-Century Courts and Offices. Ann Arbor: The University of Michigan Press, 2010.

Stanley, Amy Dru. From Bondage to Contract: Wage Labor, Marriage, and the market in the Age of Slave Emancipation. Cambridge and New York: Cambridge University Press, 1998.

Stansell, Christine. City of Women: Sex and Class in New York, 1789-1860. New York: Alfred A. Knopf, 1986.

Stormer, Nathan. Articulating Life's Memory: US Medical Rhetoric about Abortion in the Nineteenth Century. Lanham, MD: Lexington, Books, 2002.

Sign of Pathology: U.S. Medical Rhetoric on Abortion, 1800s-1960s. University Park: The Pennsylvania State University Press, 2015.

Suzuki, Akihito. Madness at Home: the Psychiatrist, the Patient, and the Family in England, 1820-1860. Berkeley and Los Angeles: University of California Press, 2006.

Thompson, F.M.L. The Rise of Respectable Society: A Social History of Victorian Britain, 1830-1900. Cambridge, Massachusetts: Harvard University Press, 1988.

Timmermans, Stefan. Postmortem: How Medical Examiners Explain Suspicious Deaths. London: The University of Chicago Press, 2006.

Tracy, Sarah W. Alcoholism in America: From Reconstruction to Prohibition. Baltimore: The Johns Hopkins University Press, 2005.

Tracy, Sarah W. and Caroline Jean Acker, eds. Altering American Consciousness: the History of Alcohol and Drug Use in the United States, 1800-2000. Amherst: The University of Massachusetts Press, 2004.

Ussher, Jane M. Women's Madness: Misogyny or Mental Illness? Amherst: The University of Massachusetts Press, 1991.

Walkowitz, Judith R. Prostitution and Victorian Society: Women, Class, and the State. Cambridge: Cambridge University Press, 1980. 
Weaver, John C. A Sadly Troubled History: The Meanings of Suicide in the Modern Age. Montreal: McGill-Queen's University Press, 2009.

Weaver, John C. and David Wright, eds. Histories of Suicide: International Perspectives on Self-Destruction in the Modern World. Toronto: University of Toronto Press, 2008.

Werth, James L. Rational Suicide?: Implications for Mental Health Professionals. Washington, D.C.: Taylor and Francis, 1996.

Whites, LeeAnn. Gender Matters: Civil War, Reconstruction, and the Making of the New South. New York: Palgrave Macmillan, 2005.

Whites, LeeAnn, Mary C. Neth, and Gary R. Kremer, eds. Women in Missouri History: In Search of Power and Influence. Columbia: University of Missouri Press, 2004.

Wood, Sharon E. The Freedom of the Streets: Work, Citizenship, and Sexuality in a Gilded Age City. Chapel Hill and London: The University of North Carolina Press, 2005.

$\underline{\text { Secondary Sources_-Unpublished }}$

The Biographical Directory of the United States Congress: 1774-Present, http://bioguide.congress.gov/scripts/biodisplay.pl?index=B000719 [Accessed January 8, 2012].

Missouri Coroners' and Medical Examiners' Association. http://www.mcmea.org/index.html.

Office of the Medical Examiner.

http://www.stlouisco.com/HealthandWellness/MedicalExaminer. 


\section{VITA}

Sarah Lirley McCune began to study the politics of death and death investigations in the late nineteenth century when working on her master's thesis at the University of Missouri from 2010 to 2012. In addition to studying how deaths were investigated and why some were interpreted differently than others, she enjoys researching the history of women, gender, and disability. 